WSRC-TR-2000-00419

SRT-RPP-2000-00036

Revision 0

\title{
Small-Scale Ion Exchange Removal of Cesium and Technetium from
} Envelope B Hanford Tank 241-AZ-102

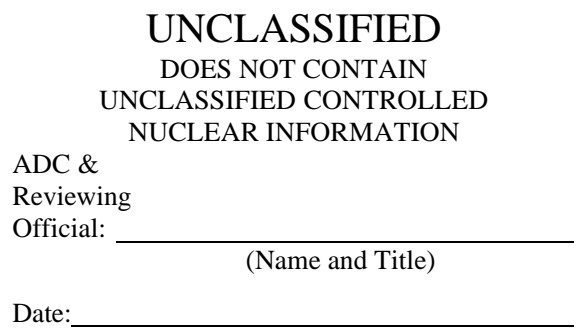

Westinghouse Savannah River Company

Savannah River Site

Aiken, SC 29808

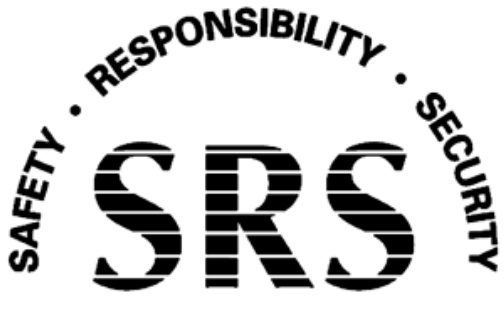

Prepared for the U.S. Department of Energy under Contract No. DE-AC09-96SR18500 
This document was prepared in conjunction with work accomplished under Contract No.

DE-AC09-96SR18500 with the U.S. Department of Energy.

\section{DISCLAIMER}

This report was prepared as an account of work sponsored by an agency of the United States Government. Neither the United States Government nor any agency thereof, nor any of their employees, makes any warranty, express or implied, or assumes any legal liability or responsibility for the accuracy, completeness, or usefulness of any information, apparatus, product or process disclosed, or represents that its use would not infringe privately owned rights. Reference herein to any specific commercial product, process or service by trade name, trademark, manufacturer, or otherwise does not necessarily constitute or imply its endorsement, recommendation, or favoring by the United States Government or any agency

thereof. The views and opinions of authors expressed herein do not necessarily state or reflect those of the United States Government or any agency thereof.

This report has been reproduced directly from the best available copy.

Available for sale to the public, in paper, from: U.S. Department of Commerce, National Technical Information Service, 5285 Port Royal Road, Springfield, VA 22161, phone: (800)

553-6847, fax: (703) 605-6900, email: orders@ntis.fedworld.gov online ordering: http://www.ntis.gov/ordering.htm

Available electronically at http://www.doe.gov/bridge

Available for a processing fee to U.S. Department of Energy and its contractors, in paper, from: U.S. Department of Energy, Office of Scientific and Technical Information, P.O. Box 62, Oak Ridge, TN 37831-0062, phone: (865 ) 576-8401, fax: (865) 576-5728, email: reports@ adonis.osti.gov 
WSRC-TR-2000-00419

SRT-RPP-2000-00036

Revision 0

KEYWORDS:

Hanford River Protection Project Ion Exchange

Cesium

Technetium

241-AZ-102

\section{Small-Scale Ion Exchange Removal of Cesium and Technetium from Envelope B Hanford Tank 241-AZ-102}

Previous Document \#: BNF-003-98-0236

SAVANNAH RIVER TECHNOLOGY CENTER

N. M. Hassan

W. D. King

D. J. McCabe

M. L. Crowder

January 17, 2001

Westinghouse Savannah River Company

Savannah River Site

Aiken, SC 29808

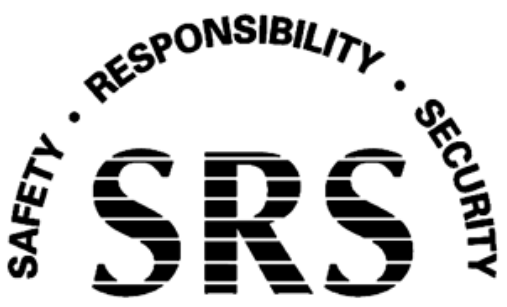

Prepared for the U.S. Department of Energy under Contract No. DE-AC09-96SR18500

SAVANNAH RIVER SITE 
WSRC-TR-2000-00419

SRT-RPP-2000-00036

Revision 0

DOCUMENT: $\quad$ WSRC-TR-2000-00419 (SRT-RPP-2000-00036)

TITLE:

Small-Scale Ion Exchange Removal of Cesium and Technetium from

Envelope B Hanford Tank 241-AZ-102

\section{APPROVALS}

Date:

Neguib Hassan (ATS/SRTC)

Date:

William King (WTT/SRTC)

Date:

Daniel McCabe (WTT/SRTC)

Date:

Mark Crowder (ATS/SRTC)

Date:

Steven Wach, RPP Pretreatment Manager

Date:

Major Thompson, Technical Reviewer (ATS/SRTC) 


\section{Table of Contents}

List of Tables $\quad$ iv

List of Figures $\quad$ V

SUMMARY vi

1.0 INTRODUCTION 1

2.0 EXPERIMENTAL 2

2.1 Materials 2

2.2 Equipment 3

2.3 Procedure 4

2.3.1 Batch Contact Tests 4

2.3.2 Cesium Column Operation $\quad 5$

2.3.3 Technetium Column Operation 6

$\begin{array}{lll}3.0 & \text { RESULTS AND DISCUSSION } & 7\end{array}$

3.1 Batch Distribution Coefficients $\quad 7$

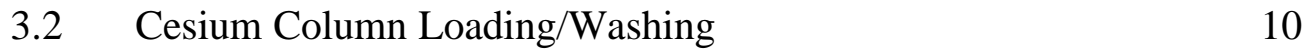

3.3 Cesium Column Elution/Regeneration $\quad 12$

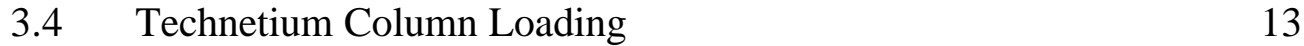

$\begin{array}{ll}3.5 & \text { Technetium Column Elution } \\ 3.6 & 14\end{array}$

$\begin{array}{lll}3.6 & \text { Product Characterization } & 14\end{array}$

$\begin{array}{lll}4.0 & \text { CONCLUSIONS } & 16\end{array}$

$\begin{array}{lll}5.0 & \text { QUALITY ASSURANCE } & 18\end{array}$

$\begin{array}{lll}6.0 & \text { REFERENCES } & 18\end{array}$

$\begin{array}{lll}7.0 & \text { APPENDIX } & 36\end{array}$

7.1 Attachment 1. As-prepared Tank 241-AZ-101 Simulant

Composition 36

7.2 Attachment 2. Initial Analysis of SuperLig ${ }^{\circledR} 644$ Guard Column Grab Samples 37

7.3 Attachment 3. SuperLig ${ }^{\circledR} 644$ Guard Column Effluent Composite Bottle Analysis

7.4 Attachment 4. SuperLig ${ }^{\circledR} 644$ Guard Column Effluent Fractions Cs-137 Breakthrough Profile with the AZ-102 Sample

7.5 Attachment 5. SuperLig ${ }^{\circledR} 644$ Batch Filtrate Solutions ICP-ES Analysis

7.6 Attachment 6. SuperLig ${ }^{\circledR} 644$ Column Swelling Data 
7.7 Attachment 7. SuperLig ${ }^{\circledR} 644$ Lead Column Cs Eluate ICP-ES Analysis (1:50 and 1:20 Water Dilutions)

7.8 Attachment 8. SuperLig ${ }^{\circledR} 644$ Guard Column Cs Eluate ICP-ES Analysis (1:30 $\mathrm{HNO}_{3}$ Dilution) 


\section{LIST OF TABLES}

Table 1. Envelope B (AZ-102) Filtrate Characterization Data

Table 2. $\quad$ Physical Properties of “As-received” SuperLig ${ }^{\circledR} 644$ and 639 Resins 21

Table 3. Sieve Analysis of SuperLig ${ }^{\circledR} 639$ Resin

Batch \#981015DHC-720011

Table 4. Sieve Analysis of SuperLig ${ }^{\circledR} 644$ Resin

Batch \#981020mb48-563

Table 5. Batch Distribution Coefficient Data for Cs-137 with

SuperLig ${ }^{\circledR} 644$ Resin

Table 6. Batch Distribution Coefficient Data for Tc-99 with

SuperLig ${ }^{\circledR} 639$ Resin

Table 7. Cesium Ion Exchange Column Loading Profiles

(Lead/Guard Columns)

Table 8. $\quad$ SuperLig ${ }^{\circledR} 644$ Column Wash and Regenerate Solution Characterization

Table 9. Cesium Ion Exchange Column Elution Profile (Lead Column)

Table 10. Technetium Ion Exchange Column Loading Profile (Lead column)

Table 11. Technetium Ion Exchange Column Loading Profile (Guard column) 24

Table 12. Technetium Ion Exchange Column Elution Profile (Lead Column) 25

Table 13. Characterization Data for Envelope B Decontaminated Product 26

Table 14. Characterization Data for Lead Column Cesium Eluate Product (1:50 Water Dilution)

Table 15. Characterization Data for Lead Column Cesium Eluate Product (1:30 0.5 $\mathrm{M} \mathrm{HNO}_{3}$ Dilution)

Table 16. Characterization Data for Technetium Eluate Product 


\section{LIST OF FIGURES}

Figure 1. $\quad$ Log-Log plot of cesium uptake by SuperLig ${ }^{\circledR} 644$

Figure 2. $\quad$ Log-Log plot of technetium uptake by SuperLig ${ }^{\circledR} 639$

Figure 3. Breakthrough profile for Cs-137 on SuperLig ${ }^{\circledR} 644$ resin

Figure 4. Elution profile for Cs-137 on SuperLig ${ }^{\circledR} 644$ resin

Figure 5. Breakthrough profile for Tc-99 on SuperLig ${ }^{\circledR} 639$ resin

Figure 6. Elution profile for Tc-99 on SuperLig ${ }^{\circledR} 639$ resin 


\section{SUMMARY}

To demonstrate the flow sheet parameters of the Hanford River Protection Project Waste Treatment Plant (RPP-WTP), a sample of Envelope B salt solution from Hanford Tank 241-AZ-102 was decontaminated for cesium and technetium by ion exchange. Prior to ion exchange treatment, the sample was filtered to remove entrained solids. Radioactive cesium and technetium removal was accomplished with two sets of ion exchange columns containing new resin. Each set was connected as a series of two columns in lead-guard configuration. The ion exchange process steps for decontamination of Envelope B were the same as previously described ${ }^{1,2}$ and briefly include: 1) resin preconditioning, 2) loading, 3) caustic wash and water rinsing, 4) elution, and 5) regeneration. In order to determine the number of column volumes (CV) of feed sample to process to reach the $50 \%$ breakthrough point, batch distribution coefficients $\left(\mathrm{K}_{\mathrm{d}}\right)$ and wet densities of the resins were determined. The $\mathrm{K}_{\mathrm{d}}$ values were determined over a wide range of cesium and technetium equilibrium concentrations in order to generate equilibrium isotherms. The decontaminated Envelope B sample product was used in demonstration of the Low-Activity Waste (LAW) vitrification process. The concentrated cesium and technetium eluate products were used for HighLevel Waste (HLW) vitrification demonstration. Vitrification study results will be reported separately.

Standard distribution coefficients for Cs-137 with SuperLig ${ }^{\circledR} 644$ resin averaged $1685 \mathrm{~mL} / \mathrm{g}$. Based on a resin density of $0.4 \mathrm{~g} / \mathrm{mL}$, the number of column volumes required to reach $50 \%$ Cs breakthrough ("lambda value") was estimated as 674 . Prior work $^{2}$ indicated that the actual $50 \%$ breakthrough point would be observed at $37 \%$ of this value (i.e. approximately 249 column volumes of feed could be processed). The technetium distribution coefficient with SuperLig ${ }^{\circledR} 639$ resin was $883 \mathrm{~mL} / \mathrm{g}$ and the estimated number of column volumes to process to reach $50 \%$ Tc breakthrough (lambda value) was estimated as 415 (based on a resin density of $0.47 \mathrm{~g} / \mathrm{mL}$ ). Batch re-contact experiments showed that the predominant form of technetium in Envelope B (AZ-102) salt solution was pertechnetate ion $\left(\mathrm{TcO}_{4}{ }^{-}\right)$that could readily be extracted by the SuperLig ${ }^{\circledR} 639$ resin. Equilibrium isotherms were obtained for both Cs and Tc and the isotherm data were correlated with the Freundlich equation.

The Cs ion exchange column performance was unexpectedly poor. The breakthrough profile was approximately linear in shape, approaching $45 \% \mathrm{Cs}$ breakthrough after 89 column volumes were processed through the lead column. The guard column breakthrough exhibited a sigmoidal shape with $11 \%$ Cs breakthrough at 89 column volumes. The area under the breakthrough curve for the guard column was $7.36 \mathrm{E}+04 \mu \mathrm{Ci}$. This corresponds to an overall decontamination factor of 41 for the leadguard column combination (i.e. $\mathrm{DF}=(89 \mathrm{CV}$ x $32 \mathrm{~mL} \times 1.07 \mathrm{E}+03 \mu \mathrm{Ci} / \mathrm{mL}) / 7.36 \mathrm{E}+04$ $\mu \mathrm{Ci}$, where $32 \mathrm{~mL}$ is the size of one column volume, and $1.07 \mathrm{E}+03 \mu \mathrm{Ci} / \mathrm{mL}$ is the feed [Cs-137]). At the time of cesium-removal testing with AZ-102, the required Cs-137 decontamination factor was $\sim 580$ for the AZ-102 waste, assuming the sodium oxide waste loading in the immobilized LAW glass is $5 \mathrm{wt} \%$ and the [Cs-137] is limited to 3 
$\mathrm{Ci} / \mathrm{m}^{3}$ of glass. The corresponding limit for Cs-137 in the decontaminated Envelope B solution is $1.85 \mu \mathrm{Ci} / \mathrm{mL}$. (The calculated effluent composite [Cs-137] based on integration of the guard column breakthrough profile is $25.8 \mu \mathrm{Ci} / \mathrm{mL}$.) The RPP-WTP design also assumes that a minimum of 50 column volumes of waste can be processed while achieving the minimum Cs-137 decontamination factor. ${ }^{3}$ Subsequent to this test, the RPP-WTP design requirements were modified and the current maximum allowable [Cs-137] in the immobilized LAW glass is $0.3 \mathrm{Ci} / \mathrm{m}^{3}$. Consequently. the required Cs- 137 decontamination factor is approximately 6,000 for the AZ-102 waste. The corresponding limit for Cs-137 in the decontaminated Envelope B solution is $0.185 \mu \mathrm{Ci} / \mathrm{mL}$. The poor Cs-137 removal performance may be attributed to in situ precipitation of metal hydroxides in the ion exchange bed, or could be characteristic of the Tank 241-AZ-102 sample, which has lower ionic strength and higher cesium content than all other samples tested. Evidence of in situ precipitation was provided by successive depletion of $\mathrm{Al}$ and Ca from batch re-contacts of AZ-102 filtrate solution with SuperLig ${ }^{\circledR} 644$ resin. In addition, these metals were depleted in the decontaminated product relative to the feed concentration. The aluminum decreased by $47 \%$, and the calcium by $99 \%$, although sample dilution accounted for $19 \%$ of these reductions.

The lead cesium column was effectively eluted with $0.5 \mathrm{M} \mathrm{HNO}_{3}$ at $25{ }^{\circ} \mathrm{C}$. The elution data indicated that up to $98 \%$ of elutable cesium was removed after 5 column volumes and less than $1 \%$ of the feed cesium concentration remained in the eluate after 12.0 column volumes. The elution achieved the design assumption of $\leq 15$ column volumes of eluate solution to reduce the cesium concentration in the eluate to less than $1 \%$ of the feed concentration. Some eluate samples indicated that in situ precipitation had occurred, but the analyses were widely variable and could not confirm this hypothesis. Further research is needed to define the reasons for the observed performance of SuperLig ${ }^{\circledR} 644$ resin when treating AZ-102 waste solution.

Tc ion exchange column performance was better than expected for the cesiumdecontaminated effluent. Because of the high Cs-137 content in the Cs column effluent, only guard column composite fractions \#1 and \#2 ( $950 \mathrm{~mL})$ from the Cs column experiment were combined and processed through the technetium ion exchange columns. (The total volume of solution processed through the cesium columns was $\sim 2.8 \mathrm{~L}$.) Technetium breakthrough was only $9.6 \%$ after 170 column volumes of feed was processed through the lead column (5.5 $\mathrm{ml}$ of resin). The guard column (5.5 $\mathrm{ml}$ of resin) maintained less than $0.04 \%$ Tc-99 breakthrough during the entire column run, which was terminated when the feed sample was consumed. The Tc-99 percent removal (calculated from the area beneath the guard column breakthrough curve) after processing 127 column volumes of solution was $99.97 \%$. This corresponds to an overall decontamination factor of 3.3E+03 for the lead-guard column combination. (Note: The difference in number of column volumes processed between the lead and guard columns is due to sampling and sample line purging between columns.)

RPP-WTP specification 2 for the production of immobilized LAW (ILAW) glass requires that the Tc-99 concentration in the glass average less than $0.1 \mathrm{Ci} / \mathrm{m}^{3}$ and that a minimum of $80 \%$ of the Tc-99 be removed from the LAW solutions. ${ }^{4}$ The Tc-99 
removal requirements are to be averaged over the ILAW glass containers produced and returned to the DOE-ORP for disposal. Up to $75 \%$ of the Tc-99 in some of the candidate LAW feed solutions (e.g., tank 241-AN-102 and 241-AN-107) is not in the pertechnetate form and cannot be separated using ion exchange materials. Therefore, the RPP-WTP must remove more than $80 \%$ of the Tc-99 from some candidate LAW solutions (e.g., tank 241-AZ-102 waste) in order to achieve a running average Tc-99 removal of $80 \%$ for all candidate LAW feed solutions to the RPP-WTP. The required minimum Tc-99 decontamination factor for the AZ-102 waste is $50,{ }^{5}$ corresponding to a limit of $6.18 \mathrm{E}-02$ $\mu \mathrm{Ci} / \mathrm{ml}$ for Tc-99 in the decontaminated Envelope B solution. The required minimum Tc-99 decontamination factor is to be achieved while processing a minimum of 100 column volumes of waste solution. The small-scale column test conducted with the cesium decontaminated tank 241-AZ-102 waste sample easily surpassed the minimum required Tc-99 decontamination factor and waste processing requirement.

Technetium elution from the lead column was accomplished with de-ionized water at $25{ }^{\circ} \mathrm{C}$. The elution curve exhibited slightly better performance than expected for the first 20 column volumes. However, the overall elution rate was very slow due to incomplete column loading. The elution cycle was terminated after 34 column volumes, although later analyses indicated that the final eluent sample contained $8 \%$ of the initial Tc-99 concentration. An estimated 5\% of the Tc-99 loaded on the column remained following the termination of the elution. The RPP-WTP design criterion requires the final Tc eluate sample to contain less than $1 \%$ of the initial Tc-99 concentration. Testing is planned to identify methods for reducing the eluent volume, such as eluting with water at 60 to $70{ }^{\circ} \mathrm{C}$. The RPP-WTP design basis has subsequently assumed that 22 column volumes of warm water at $60-70{ }^{\circ} \mathrm{C}$ will be used to elute the column. ${ }^{6}$ Since the volume of solution processed during the column-loading phase was better than expected, long elution cycles can be accommodated in the process.

Characterization data showed that the cesium and technetium content in the small portion (composite of cesium column effluent fractions \#1 and \#2) of decontaminated Envelope B product solution were 0.65 and $1.29 \mathrm{E}-04 \mu \mathrm{Ci} / \mathrm{mL}$, respectively. The decontaminated product solution met the acceptance criteria for LAW vitrification of 1.85 and $6.18 \mathrm{E}-02 \mu \mathrm{Ci} / \mathrm{mL}$ for Cs-137 and Tc-99, respectively (assuming $5 \mathrm{wt} \%$ sodium oxide loading in the ILAW glass), but not the modified design limit for Cs-137 of $0.185 \mu \mathrm{Ci} / \mathrm{ml}$. The chemical compositions in the final decontaminated product and eluate concentrates were as expected with the exception of the cesium eluate composite. Based on analysis of the cesium eluate, chloride and chromium appear to be concentrated by the SuperLig ${ }^{\circledR} 644$ ion exchange resin, relative to other ions, such as sodium. Although variable, the aluminum, calcium, and silicon appear to have been concentrated by the lead column, but not the guard column. This further supports the hypothesis that precipitates formed and were filtered from solution by the resin, leading to reduced column performance.

Conditions of the tests mimicked the planned plant operating conditions to the extent feasible. The waste feed sodium concentration was approximately half that planned during RPP-WTP operations, but this was necessary due to the limited volume of 
Envelope B sample available for process verification testing. Additionally, the design basis assumption for elution of the technetium ion exchange columns was modified following the test with Envelope B solution to use water at $60-70{ }^{\circ} \mathrm{C}$. The flow rate of liquid through the columns during each processing step was maintained at the same contact times (i.e., bed volumes per hour) but not the same superficial velocities as is planned for the full-scale operation. Quantities of solutions used for resin pretreatment, elution, and regeneration were consistent with the planned conditions, adjusted for scale. The early cesium breakthrough, tentatively attributed to post-filtration precipitation or column channeling, may also occur in the facility when using these processing conditions. Further testing is needed to evaluate the cause of the poor resin performance and identify the best solution. 


\subsection{INTRODUCTION}

The pretreatment process for the Hanford River Protection Project Waste Treatment Plant is to provide decontaminated Low-Activity Waste and concentrated eluate streams for vitrification into low- and high-activity waste glass, respectively. The pretreatment includes sludge washing, filtration, precipitation, and ion exchange processes to remove entrained solids, strontium, transuranics, cesium, and technetium. The cesium (Cs) and technetium (Tc) removal is accomplished using columns of SuperLig ${ }^{\circledR} 644$ and 639 ion exchange resins, respectively, from IBC Advanced Technologies. The resins have been shown to selectively remove cesium and technetium (as anionic pertechnetate) from alkaline salt solutions. The efficiency of ion exchange column loading and elution is a complex function involving feed compositions, equilibrium and kinetic behavior of ion exchange resins, diffusion, and the ionic strength and $\mathrm{pH}$ of the aqueous solution. A previous experimental program completed at the Savannah River Technology Center ${ }^{2}$ demonstrated the conceptualized flow sheet parameters with a "pseudo-Envelope B" sample. This was actually an Envelope A tank sample (AN-105) which had been adjusted to mimic Envelope B. ${ }^{7}$ The experiments also included determination of Cs and Tc batch distribution coefficients by SuperLig ${ }^{\circledR} 644$ and 639 resins and demonstration of small-scale column breakthrough and elution profiles. The Waste Treatment Plant design contractor used the experimental findings in support of preliminary design bases and pretreatment flow sheet development.

The objectives of this study as defined in the test specification ${ }^{8}$ are the following:

(1) Determine the batch distribution coefficients ( $\mathrm{K}_{\mathrm{d}}$ values) and percent removal for cesium (Cs-137) and technetium (Tc-99) ions on SuperLig ${ }^{\circledR}$ ion exchange materials (SuperLig ${ }^{\circledR} 644$ and 639) with Envelope B from Hanford Tank AZ-102 salt solution

(2) Provide equilibrium isotherm data to determine the parameters for successful modeling of the ion exchange column breakthrough

(3) Demonstrate Cs-137 and Tc-99 column loading and elution profiles for Envelope B using SuperLig ${ }^{\circledR} 644$ and 639 ion exchange resins, respectively

(4) Provide decontaminated (pretreated) product samples for vitrification into lowactivity waste glass and concentrated eluate product samples for vitrification into high-activity waste glass

(5) Provide information on the composition of SuperLig ${ }^{\circledR} 644$ column regenerate solutions and caustic displacement and water wash solutions used between loading and elution cycles 
The batch contact experiments were performed to determine the equilibrium distribution coefficients ( $\mathrm{K}_{\mathrm{d}}$ values) and percent removal for cesium and technetium ions. The $\mathrm{K}_{\mathrm{d}}$ values represent a measure of the equilibrium distribution between the aqueous phase and the ion exchanger at a specific solid-to-liquid ratio. Also the $\mathrm{K}_{\mathrm{d}}$ values provide valuable information on selectivity, capacity, and affinity of an ion exchange material to remove ions from complex aqueous solutions. Specific tests are performed by the addition of a small quantity of ion exchange material into a small volume of salt solution containing a known exchangeable ion(s). The factors that affect the $\mathrm{K}_{\mathrm{d}}$ values and percent removal of the ion(s) include the temperature, initial concentration of the ions in solution, and the solid/liquid ratio during the contact. Duration of the contact must be sufficient to achieve equilibrium or a constant comparative value must be used. The loading capacity for the ion exchange columns is determined from batch $\mathrm{K}_{\mathrm{d}}$ experiments conducted at the same conditions as those of the columns. The $\mathrm{K}_{\mathrm{d}}$ values are also determined at different equilibrium concentrations to establish a robust ion exchange decontamination process across the broad range of cesium and technetium concentrations that will be encountered as the solution passes through the columns. These data will be used as input to a computer model to determine the scale-up parameters. The computer modeling work will be reported in a separate document. ${ }^{9}$

The cesium column experiment was performed in the shielded High-Level Cells at the Savannah River Technology Center. After cesium decontamination, a portion of decontaminated AZ-102 sample was transferred to the Intermediate-Level Cells where the technetium ion exchange column experiments were performed. The experiments were conducted at ambient cell temperatures $\left(\sim 25^{\circ} \mathrm{C}\right)$ using a separate set of columns for the cesium and technetium removal tests. Each set consisted of two columns connected in series, one as the lead column and the other as the guard column. The cesium columns were $2.7 \mathrm{~cm}$ in diameter and each column was packed with $32 \mathrm{~mL}$ of SuperLig ${ }^{\circledR} 644$ resin. The technetium columns were $\sim 1 \mathrm{~cm}$ in diameter and each contained $\sim 5.5 \mathrm{~mL}$ of SuperLig ${ }^{\circledR} 639$ resin. For each set of columns, the feed sample was allowed to pass through the lead column and collected from the guard column in portions. The effluent solutions from the lead and guard columns were periodically sampled during column loading to detect early breakthrough and ensure that the effluent concentration did not exceed $50 \%$ of the influent concentration. Once the analytical results for the guard column effluent fractions were received and the effluent was confirmed to meet the LAW acceptance criteria, the fractions were combined and further characterized to verify that the effluent met the vitrification process acceptance criteria.

\subsection{EXPERIMENTAL}

\subsection{Materials}

Envelope B (Hanford Tank 241-AZ-102) salt solution was used for determination of batch distribution coefficients and column breakthrough performance tests. The solution received from Hanford was filtered and characterized, which is reported elsewhere. ${ }^{10}$ After filtration, the filtrate had a measured density of $1.15 \mathrm{~g} / \mathrm{mL}$ and initial 
Cs-137 and Tc-99 concentrations of $1.14 \mathrm{E}+03 \mu \mathrm{Ci} / \mathrm{mL}$ and $2.67 \mathrm{E}-01 \mu \mathrm{Ci} / \mathrm{mL}$, respectively. Filtered samples were used for batch distribution coefficient experiments ( $\mathrm{K}_{\mathrm{d}}$ values) and were stored in closed poly bottles for several weeks before the column performance tests. The Cs-137 concentration in the filtered AZ-102 sample was measured again just before conducting the column run and determined to be $1.07 \mathrm{E}+03$ $\mu \mathrm{Ci} / \mathrm{mL}$. This value for the feed concentration of Cs-137 was used throughout this report. Table 1 shows the chemical and radionuclide compositions of the filtered Envelope B sample as reported by Hay. The chemical reagents used in the AZ-102 tests for resin pretreatment and column elution were sodium hydroxide and nitric acid solutions, respectively. ${ }^{11}$ These solutions were prepared from ACS certified reagents obtained from Fisher Scientific, Inc.

The ion exchange materials used for cesium and technetium removal from the Envelope B sample were SuperLig ${ }^{\circledR} 644$ (batch \# 981020MB48-563) and 639 (batch \# 981015DHC720011), respectively. IBC Advanced Technologies, American Fork, Utah, supplied the resin for testing. SuperLig ${ }^{\circledR} 644$ is a polymerized, proprietary organic material supplied as 20-70 mesh granules. SuperLig ${ }^{\circledR} 639$ is composed of polystyrene beads with an attached proprietary organic compound. The physical properties of the SuperLig ${ }^{\circledR} 644$ and 639 batches used in this study were measured and the results are presented in Table 2. The F-factor values shown in the last column (Table 2) were obtained by drying a sub-sample of the resin overnight in a vacuum oven at $105^{\circ} \mathrm{C}$. The sieve analyses for SuperLig ${ }^{\circledR} 644$ and 639 resin particles are presented in Tables 3 and 4, and have been previously reported. ${ }^{12}$

\subsection{Equipment}

The equipment used for the ion exchange column tests was assembled remotely in the shielded High- or Intermediate-Level Cells at the Savannah River Technology Center. For each experiment, two columns (SuperLig ${ }^{\circledR} 644$ or 639) were connected in series, with a sampling port between. The columns were made of medium-wall Pyrex glass tubing with inside diameters of $2.7 \mathrm{~cm}$ for Cs ion exchange with SuperLig ${ }^{\circledR} 644$ resin and 1.1 cm for Tc-99 ion exchange with SuperLig ${ }^{\circledR} 639$ resin. A plastic coating was applied to the outside walls of the columns to contain shattered glass in case of a rupture. A 200mesh stainless steel screen was fitted into the bottom of each column. Column top assemblies included a fill reservoir, a pressure gauge, a pressure relief valve, and feed inlet ports. The fill reservoir on column top assemblies also served as a vent to permit draining liquid, if necessary. The top assemblies were connected to the glass columns by glass ground joints and tightly-fitted screw caps. A ruler affixed to the column wall was used to allow observation of resin bed height changes and liquid level. All tubing connections were made of transparent polyethylene lines that had quick-connect fittings attached to each end. The lines had an inside diameter of $0.32 \mathrm{~cm}$.

The equipment used for batch contact tests consisted of 15- or 25-mL polyethylene bottles, a Mix-Max ${ }^{\circledR}$ orbital shaker, nylon filter units $(0.45 \mu \mathrm{m})$, plastic filter holders, and 
an analytical balance accurate to $\pm 0.001 \mathrm{~g}$. All batch contact experiments were performed in the Intermediate-Level Cells, allowing remote handling of materials.

\subsection{Procedures}

\subsubsection{Batch Distribution Coefficients}

All batch contact experiments were conducted in duplicate. A standard batch contact test was performed followed by two sequential re-contacts of the filtrates with fresh resin. All Cs distribution coefficients were measured with "as-received" samples of SuperLig ${ }^{\circledR} 644$ resin batch 981020 MB48-563. All Tc distribution coefficients were measured with "as-received" samples of SuperLig ${ }^{\circledR} 639$ resin batch 981015 DHC-720011.

In the "standard" cesium and technetium batch contact tests, a known volume of salt solution $(\sim 18 \mathrm{~mL})$ was added to a polyethylene bottle with a known quantity of ion exchange resin $(\sim 0.18 \mathrm{~g})$. The bottles containing solution and resin were placed on the orbital shaker and gently shaken for $24 \pm 1$ hours at ambient cell temperature $\left(26 \pm 1{ }^{\circ} \mathrm{C}\right)$. Control samples ( $18 \mathrm{~mL}$ of salt solution) were treated in the same way as those of duplicate test samples without the addition of the resin. The concentrations of Cs-137 and Tc-99 in control samples were used as the starting initial concentrations to determine the $\mathrm{K}_{\mathrm{d}}$ values and percent removed by the resin. The ambient cell temperature was recorded at the beginning and end of each test. After the contact period, the resin was separated from the sample solution by filtration through individual 0.45 -micron nylon filter units. A $1-\mathrm{mL}$ sub-sample of the filtrate was removed from the cell and analyzed by the Analytical Development Section (ADS) of the Savannah River Technology Center. Sub-samples were diluted (10:1) with de-ionized water to reduce the radiation dose rate before the samples were transferred from the shielded cell to the analytical laboratories. All dilutions and measurements were performed based on mass and corrected for the density of the solution to ensure accuracy. The concentration of the ion(s) in solution was determined by radioactive counting (Cs-137) or inductively coupled plasma mass spectroscopy (technetium at mass 99) with and without contact with the resin. The quantity of the ion(s) on the exchanger was determined by difference. No correction for any ruthenium isotope was needed in the ICP-MS data, based on the distribution of masses 100-104. Results were corrected for dilution, where appropriate.

Following the "standard" batch contact test, two (Cs) and three (Tc) sequential recontact tests of filtered salt solutions with fresh ion exchange resin were performed. In the first re-contact test, a known volume $(\sim 10 \mathrm{~mL})$ of the filtrate that had been separated from the resin used in the standard test was re-contacted with fresh ion exchange resin $(\sim 0.12 \mathrm{~g})$. The fresh resin and the filtrate were gently shaken for $24 \pm 1$ hours. After equilibration, the resin was separated from the solution by filtration with a 0.45 -micron nylon filter unit. A 1-mL sub-sample of the first re-contact filtrate was removed from the cell and submitted for analysis by radioactive counting for Cs-137 or inductively coupled plasma mass spectroscopy for Tc-99. The second re-contact was conducted by gently shaking a known volume $(\sim 7.5 \mathrm{~mL})$ of the first re-contact filtrate with fresh ion exchange resin $(\sim 0.1 \mathrm{~g})$ for 
$24 \pm 1$ hours. After equilibration, the resin was separated from the solution by filtration with a 0.45 -micron nylon filter unit. A 1-mL sub-sample of the second re-contact filtrate was submitted for analysis. A third re-contact was performed on the filtrate from Tc batch contact of the second filtrate.

\subsubsection{Cesium column operation}

The cesium columns each contained $\sim 32 \mathrm{~mL}$ (bed height: $5.7 \mathrm{~cm}$; L/D: $2.1 \mathrm{~cm}$ ) of swollen SuperLig ${ }^{\circledR} 644$ resin. (Note: The size of one column volume was defined as $32 \mathrm{~mL}$ based on the measured height of the resin bed in $0.25 \mathrm{M} \mathrm{NaOH}$ pretreatment solution.) The resin pretreatment was performed in a chemical hood. The pretreatment of the "as received" SuperLig ${ }^{\circledR} 644$ resin was conducted according to the protocol developed by the Savannah River Technology Center. ${ }^{11}$ This protocol was determined necessary for new or stored resin and it included an acid-caustic cycle that resulted in a fully swollen resin bed in the sodium form.

For the SuperLig ${ }^{\circledR} 644$ columns, the ion exchange resin pretreatment and column performance was tested with simulated Envelope B salt solution prior to initiating the run with actual Hanford material (AZ-102). The simulated run was performed with $\sim 20 \mathrm{CV}$ Envelope B (AZ-101) simulant which had been diluted to $2.8 \mathrm{M}\left[\mathrm{Na}^{+}\right]$and contained 44 $\mathrm{mg} / \mathrm{L}$ of nonradioactive Cs (calculated Tank 241-AZ-102 [Cs-137]: $39.3 \mathrm{mg} / \mathrm{L}$ ). The calculated AZ-102 simulant composition, based on the masses of chemicals added and dilution of the solution to $2.8 \mathrm{M} \mathrm{Na}^{+}$, is provided in Attachment 1. The simulant testing indicated good column performance, with $0.05 \%$ Cs breakthrough $(0.023 \mathrm{mg} / \mathrm{L} \mathrm{Cs})$ observed in the lead column effluent and $<0.007 \%$ Cs breakthrough observed in the guard column effluent after $19 \mathrm{CV}$ of simulant had been processed. The columns were fully eluted at the completion of the simulant test, and were stored in hydrogen form (water washed after elution) for several days before being transferred to the shielded cells.

Just prior to the introduction of actual Envelope B solution into the columns, $6 \mathrm{CV}$ of $0.25 \mathrm{M}$ sodium hydroxide solution was pumped down-flow through the lead and guard columns in series at a flow rate of $3 \mathrm{CV} / \mathrm{hr}$. The caustic solution hold up in the column headspace was maintained at levels equal to the resin bed volume to mimic plant design parameters. After preconditioning, the feed was introduced into the lead column at a flow rate of $2.9 \mathrm{CV} / \mathrm{hr}$ (superficial velocity: $0.27 \mathrm{~cm} / \mathrm{min}$, measured range: $0.25-0.28 \mathrm{~cm} / \mathrm{min}$ ) and the effluent was collected in 20 column volume fractions from the guard column. (Note: The reported flow rate was a volume-weighted average of rates measured for each guard column effluent collection bottle.) A sub-sample was collected from the lead column after 10 column volumes of feed had been processed, using a three-way Teflon ${ }^{\circledR}$ valve to direct liquid into the sampling line. The line was briefly flushed before each sub-sample was collected. Subsequent sub-samples were collected at 10 column volume intervals. The volume of flush and sample liquid taken from the lead column effluent reduced the total volume of liquid pumped into the guard column and caused episodes of zero flow in the guard column. 
The effluent from the guard column was routed to $1 \mathrm{~L}$ polyethylene collection bottles located at the guard column exit. Approximately 20 column volumes of effluent were collected in each bottle. The weight of effluent fractions was measured using an analytical balance; the corresponding volume was determined, dividing the effluent weight by the density of the feed. The total volume processed was $\sim 2.8 \mathrm{~L}$. A sub-sample $(\sim 5-10$ $\mathrm{mL}$ ) was collected from the guard column after 20 column volumes of effluent were collected. Subsequent sub-samples were collected in 20 column volume intervals. The samples were counted at-line with a gamma counter to monitor the progress of the column loading. The samples from the lead and guard columns were submitted to the Analytical Development Section of the Savannah River Technology Center for analysis by radioactive counting. The loading cycle was terminated when the sample feed was consumed.

After termination of the loading cycle, the liquid hold-up was drained from the column headspace until the liquid level was $1-2 \mathrm{~cm}$ above the resin. The liquid level was then reestablished with $0.1 \mathrm{M} \mathrm{NaOH}$ solution. The columns were flushed with $\sim 3 \mathrm{CV}$ of $0.1 \mathrm{M}$ sodium hydroxide and rinsed with $3 \mathrm{CV}$ of de-ionized water at a flow rate of 3 $\mathrm{CV} / \mathrm{hr}$. The pump dial was adjusted to provide a flow of $0.88 \mathrm{CV} / \mathrm{hr}$ (superficial velocity: $0.47 \mathrm{~cm} / \mathrm{min}$, measured range: $0.37-0.56 \mathrm{~cm} / \mathrm{min}$ ), which is close to the design basis flow of $1 \mathrm{CVhr}$, and the lead column was eluted with $0.5 \mathrm{M} \mathrm{HNO}_{3}$. Eluate fractions were collected in $2 \mathrm{CV}$ increments. Sub-samples $(\sim 3-5 \mathrm{~mL})$ were collected periodically and analyzed by radioactive counting. After completion of the acid elution, the column was washed with 3 column volumes of de-ionized water and stored in water.

\subsubsection{Technetium column operation}

The technetium removal from Envelope B (Hanford Tank 241-AZ-102) salt solution was accomplished with a set of two ion exchange columns in series. The columns were freshly-prepared from new resin that had not been used with other Hanford samples or simulants. Quartz wool and glass beads were not used to restrain the resin in the column, as was the case in previous experiments, since the density of the solution was low. The wet volume of the resin in the lead and guard columns was $\sim 5.5 \mathrm{~mL}$ each (defined as 1 $\mathrm{CV}$ ). The purpose of the guard column was to further decontaminate the feed sample in order to meet the Low-Activity Waste vitrification acceptance criteria. ${ }^{4}$

On the day of the experiment, the resin was preconditioned with $3 \mathrm{CV}$ of $1 \mathrm{M}$ $\mathrm{NaOH}$ in one hour. The feed to the technetium ion exchange columns was a portion of the Cs-decontaminated effluent (fractions \#1 and \#2, total volume $\sim 950 \mathrm{~mL}$ ), which had been diluted with approximately $190 \mathrm{~mL}$ of $0.25 \mathrm{M} \mathrm{NaOH}$ solution (based on the measured $\left[\mathrm{Na}^{+}\right]$of $2.2 \mathrm{M}$ ) from pretreatment of the cesium ion exchange columns. The average Tc99 concentration in the column feed was $13.1 \mathrm{mg} / \mathrm{L}$. The feed was pumped down-flow through the lead column at 3 column volumes per hour. The flow rate was adjusted during the early stages of the run to accommodate for the density change between the conditioning solution and the feed. The flow rate was periodically checked by weighing samples collected from the guard column for 10 minutes. Also, the weight of effluent fractions at 20 column volume intervals was measured and the flow rate was verified using the density of the effluent solutions. 
Sub-samples ( $3 \mathrm{~mL})$ were collected from the lead column after 5 and 10 column volumes of feed were processed through the lead column. Subsequent sub-samples were collected at 10 column volume intervals. Sub-samples were collected through a three-way Teflon ${ }^{\circledR}$ valve at the lead column exit sampling line. The effluent from the lead column was routed to sample vials located under the sampling line. The line was flushed for 3 minutes, followed by 10-minute sample collection. Sub-samples $(\sim 1 \mathrm{~mL})$ of effluent were submitted without dilution to the Analytical Development Section of the Savannah River Technology Center for analysis of Tc-99 by inductively coupled plasma mass spectroscopy (ICP-MS). When not in sampling mode, the effluent from the lead column was allowed to pass down-flow into the guard column, which served to further decontaminate the feed sample. Sampling the lead column resulted in a discontinuous flow rate for the guard column, where flow stops for 13 minutes approximately every 3.3 hours. The guard column effluent was collected in 20 column volume increments, then sampled for 10 minutes. Sub-samples $(\sim 1 \mathrm{~mL})$ from the guard column were submitted without dilution for analysis to the Analytical Development Section of Savannah River Technology Center. The column loading was terminated when the available feed was consumed.

Upon completion of the technetium loading cycle, the feed hold-up in the column headspace was drained from the columns until the liquid level was $\sim 1-2 \mathrm{~cm}$ above the surface of the resin bed. The columns were then washed in series with 2 TAV (TAV = total apparatus volume; the volume of tubing and liquid headspace in the lead column; $11 \mathrm{~mL}$ ) of $0.1 \mathrm{M}$ sodium hydroxide. The wash effluent solutions were collected from the guard column in 2 column volume portions. Sub-samples $(\sim 1 \mathrm{~mL})$ were collected from the guard column in $1 \mathrm{CV}$ increments.

Upon completion of the column wash cycle, the lead and guard columns were disconnected. The flow rate through the lead column was adjusted to $1 \mathrm{CV} / \mathrm{hr}$. The eluent (de-ionized water) was pumped down-flow into the lead column and collected in two column volume fractions. Eluate fractions were collected into $30-\mathrm{mL}$ polyethylene bottles. The elution was continued until 34 column volumes of water had passed through the column. Sub-samples of the eluate were collected between fractions and were analyzed for Tc-99 by ICP-MS.

\subsection{RESULTS AND DISCUSSION}

\subsection{Batch Distribution Coefficients}

Batch contact experiments were performed to determine equilibrium distribution coefficients ( $K_{d}$ values) and percent removal for Cs-137 and Tc-99. The batch contact experiments involve the addition of a small quantity of ion exchange materials into a known volume of the salt solution containing known quantities of $\mathrm{Cs}$ and Tc ions. The concentration of $\mathrm{Cs}-137$ in solution was determined by radioactive counting before and after contact with the SuperLig ${ }^{\circledR} 644$ resin. The concentration of Tc-99 before and after contact with the SuperLig ${ }^{\circledR} 639$ resin was determined by inductively coupled plasma mass 
spectroscopy (ICP-MS). The quantity of adsorbed ions $\left(\mathrm{Cs}^{+}\right.$or $\left.\mathrm{TcO}_{4}^{-}\right)$on the resins was determined by difference. Batch distribution coefficients ( $\mathrm{K}_{\mathrm{d}}$ values) and percent removal were calculated from the following equations :

$$
\mathrm{K}_{\mathrm{d}}=\frac{\left(\frac{C_{i}}{C_{e}}-1\right) x V}{(M x F)}
$$

and

$$
\% \mathrm{R}=\frac{\left(C_{i}-C_{e}\right) \times 100}{C_{e}}
$$

where $C_{i}$ is the initial analyte concentration in solution, $C_{e}$ is the final (equilibrium) analyte solution concentration, $\mathrm{V}$ is the volume of liquid sample, $\mathrm{M}$ is the "as received" mass of the resin, and $\mathrm{F}$ is the mass of dried resin divided by the mass of "as received" resin (i.e., the dry weight correction or F-factor).

The $\mathrm{K}_{\mathrm{d}}$ values and percent removals $(\% \mathrm{R})$ for Cs-137 are presented in Table 5. The percent relative standard deviations (\% RSD) for the standard batch contact, first and second re-contacts were $3.57,3.83$, and $24 \%$, respectively. This indicates that sample duplicate results were generally good for the first two batch contacts, but a 24\% RSD for the second batch re-contact is considered statistically poor. The standard $\mathrm{K}_{\mathrm{d}}$ value for absorption of Cs-137 from Envelope B (Tank AZ-102) supernate on SuperLig ${ }^{\circledR} 644$ resin was $1685 \mathrm{~mL} / \mathrm{g}$ at an equilibrium Cs concentration of $1.61 \mathrm{E}-05 \mathrm{M}$. The $\mathrm{K}_{\mathrm{d}}$ values for the first and second re-contacts, each using prior filtrate with fresh ion exchange resin, were 1862 and $936 \mathrm{~mL} / \mathrm{g}$ at equilibrium cesium concentrations of $8.07 \mathrm{E}-07$ and $6.79 \mathrm{E}-08 \mathrm{M}$, respectively. Thus, the $\mathrm{K}_{\mathrm{d}}$ values for cesium increase with the equilibrium cesium concentration to a maximum loading value, after which the $\mathrm{K}_{\mathrm{d}}$ values drop significantly. The drop in $\mathrm{K}_{\mathrm{d}}$ values may be attributed to the increase in the sodium to cesium ratio in solution. A similar finding has been reported for Envelope C (Tank AN-102) salt solution on SuperLig ${ }^{\circledR} 644$ resin. $^{13}$ Alternatively, the "as-received" SuperLig ${ }^{\circledR} 644$ resin has recently been found to contain approximately $20 \mathrm{wt} \%$ potassium. Dissolution of potassium salts during batch contacts would result in successively higher solution $\mathrm{K}^{+}$concentrations with each contact. The higher potassium concentrations may decrease the cesium $\mathrm{K}_{\mathrm{d}}$, particularly during multiple batch contact tests. This does not affect column tests, as the pretreatment protocol removes the potassium.

The uptake of cesium by SuperLig ${ }^{\circledR} 644$ resin was calculated from the concentration of Cs-137 on the resin, the isotopic ratio of Cs-137 to total cesium in solution, the volume of the solution, and the mass of the resin. Figure 1 shows a log-log plot of cesium uptake vs. equilibrium concentration for the limited data set of 3 points. Thus, for this sample, a linearized Freundlich equation may generally be written as

$$
\log q=\log K+\frac{1}{n} \log C_{e}
$$


where $\mathrm{q}$ is the cesium uptake per unit mass of resin, $\mathrm{C}_{\mathrm{e}}$ is the cesium concentration in the solution phase at equilibrium. The empirical constants, $\mathrm{K}$ and $\mathrm{n}$ can be determined by a regression analysis. It can be seen that the equilibrium data for cesium on SuperLig ${ }^{\circledR} 644$ are very well represented $\left(\mathrm{R}^{2}=0.998\right)$ by the Freundlich expression

$$
q=5.52 C_{e}^{1.74}
$$

A detailed analysis of the data correlation and column modeling will be reported in a separate document.

The loading of cesium on SuperLig ${ }^{\circledR} 644$ at $50 \%$ Cs breakthrough was estimated from the mean standard $K_{d}$ value and the wet density ${ }^{12}(\rho)$ of the resin. The lambda $(\lambda)$ value calculated for Envelope B (AZ-102) supernate was calculated as follows.

$$
\lambda=\mathrm{K}_{\mathrm{d}} \times \rho=1685 \mathrm{~mL} / \mathrm{g} \times 0.4 \mathrm{~g} / \mathrm{mL}=674
$$

Thus, the estimated number of column volumes of feed that can be processed before $50 \%$ Cs-137 breakthrough is 674 . Previous work ${ }^{2}$ with other samples, however, indicated that the actual cesium breakthrough would occur at $37 \%$ of this value. (Note: this discrepancy may be attributable to the mass of the potassium salt initially on the resin.) Therefore, the adjusted lambda value for Envelope B was 249 column volumes.

Table 6 shows the $\mathrm{K}_{\mathrm{d}}$ values (mean of duplicate samples) and percent removals for Tc-99 on SuperLig ${ }^{\circledR} 639$ resin. The standard $K_{d}$ value for Tc-99 was $883 \mathrm{~mL} / \mathrm{g}$. The $\mathrm{K}_{\mathrm{d}}$ value for the first re-contact increased to $951 \mathrm{~mL} / \mathrm{g}$ as the initial concentration of Tc-99 in solution decreased from $1.43 \mathrm{E}-5$ (standard contact) to $1.25 \mathrm{E}-6 \mathrm{M}$ (first recontact). The $\mathrm{K}_{\mathrm{d}}$ values for the second and third re-contacts decreased to 430 and $204 \mathrm{~mL} / \mathrm{g}$, respectively. The percent relative standard deviation (RSD) for the standard, first, second, and third batch re-contacts were $2.9 \%, 14.7 \%, 33.2 \%$, and $5.9 \%$, respectively. This indicates the sample analyses were generally good, with the exception of the second re-contact, which exhibited a statistically poor $33.2 \%$ RSD. Thus, during the standard contact $1.25 \mathrm{E}+04$ $\mu \mathrm{g} / \mathrm{L}$, or $90 \%$ of the technetium in the feed sample, was removed by the resin. In the subsequent first, second, and third re-contacts the Tc-99 removals relative to the initial feed concentration were $9.4,0.8$, and $0.1 \%$, respectively. These results suggest that $\sim 99.9 \%$ of the technetium in Envelope B (AZ-102) was extractable pertechnetate species.

The uptake of technetium by SuperLig ${ }^{\circledR} 639$ resin was calculated from the Tc-99 concentration on the resin, the volume of the solution, and the mass of the resin. Figure 2 shows a log-log plot of Tc-99 uptake vs. equilibrium concentration for the Envelope B sample. The equilibrium data for Tc-99 on SuperLig ${ }^{\circledR} 639$ are well represented $\left(\mathrm{R}^{2}=\right.$ 0.984 ) by the Freundlich expression.

$$
q=4.63 C_{e}^{1.47}
$$


A detailed analysis of the data correlation and column modeling will be reported in a separate document.

The technetium loading at 50\% Tc breakthrough was estimated from the batch distribution coefficient and the wet density of the SuperLig ${ }^{\circledR} 639$ resin. $^{12}$ The estimated number of column volumes of feed to process to reach $50 \%$ Tc breakthrough $(\lambda)$ was calculated as follows. ${ }^{9,14,15}$

$$
\lambda=K_{d} \times \rho=883 \mathrm{~mL} / \mathrm{g} \times 0.47 \mathrm{~g} / \mathrm{mL}=415
$$

Thus, an estimated 415 column volumes of Envelope B (Tank 241-AZ-102) salt solution could be processed with SuperLig ${ }^{\circledR} 639$ resin before $50 \%$ Tc breakthrough occurs.

\subsection{Cesium Column Loading/Washing}

The cesium decontamination experiment for Envelope B (AZ-102) was conducted with freshly-prepared ion exchange columns. Envelope B feed was filtered ( 0.45 micron nylon Nalgene ${ }^{\circledR}$ filters) several weeks prior to the ion exchange column experiment. Analysis of the filtrate solution indicated that the nitrate $\left(\mathrm{NO}_{3}{ }^{-}\right)$, potassium $\left(\mathrm{K}^{+}\right)$, and hydroxide $\left(\mathrm{OH}^{-}\right)$concentrations were $0.273,0.081$, and $0.109 \mathrm{M}$, respectively (Table 1 ). ICP-MS analysis indicated that the mole fractions of cesium isotopes were as follows:

\begin{tabular}{|c|c|}
\hline & Atom \% \\
\hline Cs-133 & 52 \\
\hline Cs-135 & 15 \\
\hline Cs-137 & 33 \\
\hline
\end{tabular}

Based on the isotopic distribution above, the calculated total Cs concentration in the feed sample is $2.87 \mathrm{E}-4 \mathrm{M}$. The contribution to these masses from natural abundance barium isotopes and meta-stable Ba-137m is insignificant. Based on ICP-ES analysis, the $\mathrm{Na} / \mathrm{Cs}$ and $\mathrm{K} / \mathrm{Cs}$ ratios were $9.23 \mathrm{E}+03$ and $2.82 \mathrm{E}+02$, respectively. The breakthrough data for Cs-137 on SuperLig ${ }^{\circledR} 644$ resin are shown in Table 7. Figure 3 shows the Cs137 concentration profile as a function of effluent column volumes from the lead and guard ion exchange columns. It can be seen that $45 \% \mathrm{Cs}$ breakthrough from the lead column occurred for Envelope B (AZ-102) supernate at $~ 90$ column volumes with a nearly linear slope. More than 5\% Cs breakthrough was observed after $17 \mathrm{CV}$ of feed had been processed, which is larger by a factor of $\sim 10$ than the breakthrough observed with the AZ-101 simulant $(0.05 \% \mathrm{Cs}$ breakthrough after processing $19 \mathrm{CV})$. The guard column exhibited $10 \%$ Cs breakthrough after $\sim 90$ column volumes of the AZ-102 sample were processed. (Note: Initial guard column sample analyses did not show a smooth cesium breakthrough profile (Attachment 2). However, a second set of samples was submitted for analysis which gave the results provided in Table 7 and Figure 3. The guard column effluent composite fractions were also analyzed and the results are shown in Attachments 3 and 4.) The lower than expected performance of the ion exchange 
WSRC-TR-2000-00419

SRT-RPP-2000-00036 Revision 0

columns may be attributed to in situ precipitation, which drastically impairs the hydrodynamic performance of the columns and adversely affects the column breakthrough behavior. Aluminum and calcium precipitation, in particular, is evidenced by progressive depletion of $\mathrm{Al}$ and $\mathrm{Ca}$ concentrations in the batch equilibrium contact filtrates. However, these ions were not concentrated in the cesium eluate (see below), although some variability in composition was observed. During successive filtration of batch re-contacts, the $\mathrm{Al}$ and $\mathrm{Ca}$ concentrations dropped from initial values of $7.53 \mathrm{E}+02$ and $1.08 \mathrm{E}+02 \mathrm{mg} / \mathrm{L}$ to $3.43 \mathrm{E}+01$ and $1.89 \mathrm{mg} / \mathrm{L}$, respectively (Attachment 5). Similar observations were made for the decontaminated ion exchange column effluent. The feed concentrations of aluminum and calcium were 0.0279 and $2.70 \mathrm{E}-03 \mathrm{M}$, respectively (Table 1). In the decontaminated product (Table 13), the concentrations of $\mathrm{Al}$ and $\mathrm{Ca}$ decreased to 0.0149 and $1.42 \mathrm{E}-5 \mathrm{M}$, respectively, corresponding to concentration decreases of $47(\mathrm{Al})$ and $99.5 \%(\mathrm{Ca})$. By comparison, sample dilution from mixing of the feed with the resin pretreatment solution $(0.25 \mathrm{M} \mathrm{NaOH})$ resulted in an average concentration decrease for potassium, nitrate, nitrite, and sulfate of $23 \%$ (range: 19-31\%) in the decontaminated product. These species are essentially "spectator ions" and can be used to benchmark the amount of dilution. Alternatively, the nearly linear performance of the column may be due to the inherent characteristics of this tank sample, which has much lower sodium and hydroxide concentrations and a higher cesium concentration than any other sample tested. The kinetics of the absorption of cesium have not been examined in this range, except for the brief test with diluted AZ-101 simulant, which immediately preceded this test with AZ-102. Comparison of the AZ-101 simulant composition to the actual AZ-102 sample reveals that the simulant contained a considerably higher $\mathrm{Al}$ concentration $(\sim 10 \mathrm{x})$ and a higher free hydroxide concentration $(\sim 3 \mathrm{x})$ than the AZ-102 sample. The simulant solution did not contain calcium. Sodium and potassium concentrations in the two solutions were similar.

The macroscopic swelling and shrinking behavior of the SuperLig ${ }^{\circledR} 644$ columns during the column experiment was generally consistent with previous observations. ${ }^{12}$ However, the resin swelling properties with this lower ionic strength solution differ from other samples, and may lead to a change in the absorption kinetics or channeling. The lead column resin bed volume was $32 \mathrm{~mL}$ in the $0.25 \mathrm{M} \mathrm{NaOH}$ pretreatment solution, but only shrank by $\sim 9 \%$ when the sample was introduced (see Attachment 6). The bed usually shrinks by $15-22 \%$ when $5 \mathrm{M} \mathrm{Na}^{+}$Envelope A simulant is used. ${ }^{16}$ This is consistent with progressively more shrinking with higher ionic strength, as expected. For comparison, the lead column resin bed volume during AZ-101 simulant column testing was $30.4 \mathrm{ml}$ in $0.25 \mathrm{M} \mathrm{NaOH}$ pretreatment solution and $27.3 \mathrm{~mL}$ in feed. This corresponds to an $11 \%$ volume decrease when feed was introduced. (Note: Slightly smaller resin volumes were observed for the simulant column test in both the pretreatment and the feed solutions. This observation is consistent with earlier observations that SuperLig ${ }^{\circledR} 644$ resin beds gradually increase in volume with successive acid/caustic cycles. ${ }^{16}$ ) Small changes in the bed porosity or packing density may be occurring in AZ-102 supernate which may impact performance. The resin pretreatment may need to be modified with Envelope B supernate to accommodate this sample type. The packing density of the resin in a column with this short L/D ratio $(\sim 2)$ may also play a role, although even shorter L/D ratios have been used successfully with other waste 
types. ${ }^{16}$ There was no visible indication of resin decomposition, such as color changes in the effluent solutions during column operation.

At the conclusion of the feed cycle, the columns were flushed with $3 \mathrm{CV}$ of $0.1 \mathrm{M}$ $\mathrm{NaOH}$ solution and $3 \mathrm{CV}$ of deionized water. The $\mathrm{NaOH}$ flush solution was pumped through both columns in series and collected from the guard column in $1.2 \mathrm{CV}$ increments (Table 8, Fractions 1-2). Initially, the water rinse was collected similarly (Fraction 3). (Note: The first $0.6 \mathrm{CV}$ of Fraction 3 were collected while pumping $\mathrm{NaOH}$ solution into the lead column and the last $0.6 \mathrm{CV}$ were collected while pumping water into the lead column.) The two columns were then disconnected and the remaining rinse solution was pumped through the lead column only. (The water rinse was completed independently for the guard column.) Wash fractions 4 and 5 (Table 8) were collected from the lead column collection port. The $\left[\mathrm{Na}^{+}\right]$and $\left[\mathrm{OH}^{-}\right]$concentrations of Fractions 1-3 are relatively constant and are similar to the concentrations of these species in the feed $\left(\left[\mathrm{Na}^{+}\right]: 2.65 \mathrm{M}\right.$, Free $\left[\mathrm{OH}^{-}\right]: 0.11$ M). The $\left[\mathrm{Na}^{+}\right]$and total $\left[\mathrm{OH}^{-}\right]$concentrations decreased dramatically between fractions 3 and 4, due to the change in sampling location. The Cs-137 concentration in fractions 1 and 2 are similar to the [Cs-137] in the final guard column grab sample $(112 \mu \mathrm{Ci} / \mathrm{mL})$. The cesium data are consistent with the $\mathrm{Na}^{+}$and $\mathrm{OH}^{-}$analyses and indicate that the first $2.4 \mathrm{CV}$ of solution collected during the wash cycle was primarily displaced feed solution. The concentrations of both Cs-137 and $\mathrm{Na}^{+}$decreased slightly in Fraction 3. Wash Fraction 4 exhibited the lowest concentration of Cs-137 $(31.1 \mu \mathrm{Ci} / \mathrm{mL})$. The [Cs-137] increased by a factor of 9.5 between Fractions 4 and 5, indicating that Cs elution may have begun during the water rinse. This result was surprising since the [Cs-137] concentration in the first grab sample collected during the nitric acid elution was only $18.4 \mu \mathrm{Ci} / \mathrm{mL}$ (see below). Based on this observation, the Cs-137 concentration in fraction 5 may be in error.

\subsection{Cesium Column Elution/Regeneration}

The results for cesium elution from SuperLig ${ }^{\circledR} 644$ resin with dilute nitric acid $\left(0.5 \mathrm{M} \mathrm{HNO}_{3}\right)$ at $0.88 \mathrm{CV} / \mathrm{hr}$ are shown in Table 9 and Figure 4 . Figure 4 reveals that the dilute nitric acid $(0.5 \mathrm{M})$ was effective for nearly complete removal of cesium from the lead column. The elution curve exhibits four regions, namely: neutralization, peak, exponential decay, and tailing. The neutralization region at the left end of the curve represents several column volumes of acid eluting very little cesium. During this period, the acid is probably reacting with the residual hydroxide ions in the liquid and the hydrogen ions are starting to replace sodium ions on the resin. The peak region of the curve shows a sharp peak at 5 column volumes, during which approximately $69 \%$ of the cesium in the column was eluted. The exponential decay region that follows the peak region shows a significant drop in cesium concentration within a few column volumes of acid. The final region of the elution curve shows a small tailing effect. About $1 \%$ of the initial cesium concentration remained in the eluent after 12 column volumes had passed through the column. The volume of the resin in each column decreased from $29.5 \mathrm{~mL}$ at the conclusion of the loading cycle to $22.7 \mathrm{~mL}$ during column elution. The column was eluted with a total of 22.8 column volumes of $0.5 \mathrm{M} \mathrm{HNO}_{3}$ but grab samples collected 
after $12 \mathrm{CV}$ of eluate had been processed were not analyzed. (Note that a column volume is still defined as the resin volume measured in $0.25 \mathrm{M} \mathrm{NaOH}$; i.e., $32 \mathrm{~mL}$.)

At the conclusion of the elution cycle, the lead and guard cesium columns were washed separately with $\sim 3 \mathrm{CV}$ of deionized water and were stored in water. In order to use the ion exchange columns for testing with the Envelope C Tank 241-AN-102 sample, it was necessary to add more SuperLig ${ }^{\circledR} 644$ resin to the columns. Additional resin was added to each of the columns remotely in the High-Level Cells to give a total resin volume in each column of $\sim 107 \mathrm{~mL}$ (volume in $0.25 \mathrm{M} \mathrm{NaOH}$ ). The lead and guard columns were regenerated in series with $\sim 6 \mathrm{CV}$ of $0.25 \mathrm{M} \mathrm{NaOH}$ (where the size of $1 \mathrm{CV}$ $=107 \mathrm{~mL}$ ). The regenerate solution was collected from the guard column and analyzed for Cs-137, $\mathrm{Na}^{+}$, and $\mathrm{OH}^{-}$(Table 8). Based on the reported $\mathrm{Na}^{+}$and free $\mathrm{OH}^{-}$ concentrations of 0.03 and $<0.02 \mathrm{M}$, respectively, the regenerate solution collected appears to be primarily displaced water storage solution. As expected the Cs-137 concentration is quite low as well. The regenerated columns were then used for ion exchange treatment of the large portion of the Envelope C sample from Tank 241-AN$102 .^{17}$

\subsection{Technetium Column Loading}

The planned pretreatment process flowsheet for the RPP-WTP includes ion exchange columns for cesium removal followed by columns for technetium removal. Thus, at the conclusion of the cesium ion exchange process, the cesium breakthrough data were reviewed to ensure that the Cs-decontaminated effluent fractions from the guard column met pretreatment radionuclide acceptance limits. Once such a determination was made, the effluent fractions were combined and the technetium ion exchange process commenced. Following this protocol, $950 \mathrm{~mL}$ of combined effluent fractions 1 and 2 from the cesium ion exchange column experiment was used as feed to the technetium ion exchange columns. Analysis of the feed solution by inductively coupled plasma emission spectroscopy (ICP-ES) and ion chromatography (IC) indicated the $\mathrm{Na}^{+}$and nitrate $\left(\mathrm{NO}_{3}{ }^{-}\right)$ concentrations were 2.25 and $0.27 \mathrm{M}$, respectively, giving a $\mathrm{NO}_{3}{ }^{-} / \mathrm{Tc}$ ratio of $\sim 2.0 \mathrm{E}+03$ in the feed. Nitrate anion $\left(\mathrm{NO}_{3}{ }^{-}\right)$is believed to be the primary competitor with pertechnetate anion for absorption sites on the SuperLig ${ }^{\circledR} 639$ resin. Dilution of the sample had occurred due to mixing with the $0.25 \mathrm{M}$ sodium hydroxide solution used for resin pretreatment, which mimics the planned operation of the columns in the facility. Analysis of the Tc eluate indicates nitrite, sulfate, oxalate, and chloride are adsorbed by SuperLig ${ }^{\circledR} 639$ resin, as well as nitrate.

Results of the Tc-99 lead column breakthrough are presented in Table 10. Figure 5 shows a plot of the effluent Tc-99 concentration profile $(\mathrm{C} / \mathrm{Co})$ as a function of the number of column volumes processed for the lead column. Less than $10 \%$ Tc breakthrough occurred after 170 column volumes of feed had been processed through the lead column. This is $\sim 40 \%$ of the estimated lambda value (415) projected from the standard $\mathrm{K}_{\mathrm{d}}$ measurement on the original filtered AZ-102 sample. The guard column maintained less 
than $0.04 \%$ breakthrough (Table 11). These results indicate that the lead-guard column configuration performed better than expected.

\subsection{Technetium Column Elution}

The results for technetium elution from the SuperLig ${ }^{\circledR} 639$ lead column are presented in Table 12. A plot of the Tc-99 elution profile vs. the eluent (water) column volumes is shown in Figure 6. Technetium was eluted from the SuperLig ${ }^{\circledR} 639$ resin with de-ionized water $\left(25^{\circ} \mathrm{C}\right)$ at approximately $1 \mathrm{CV} / \mathrm{hr}$. The technetium concentration in the eluate reached a peak corresponding to $\sim 19$ times the feed concentration at 12 column volumes, then exponentially decreased to 1.2 times the feed concentration at 20 column volumes. The percentages of the total technetium absorbed to the lead column collected after 10 and 20 column volumes of eluent had been processed were 16 and $95.6 \%$, respectively. Approximately $8 \%$ of the Tc-99 concentration in the feed was observed in eluate samples after 34 column volumes. The slow elution rate observed for the technetium has been reported previously. Due to the unavailability of at-line Tc monitor/analyzer, it was not possible to determine when elution was complete, so the elution was continued for up to 34 column volumes and analysis results were received later. Since the loading profile greatly exceeded the design criteria (100 CV to $50 \%$ breakthrough), these long elutions are acceptable. Testing is planned to examine ways to decrease the elution duration to decrease the amount of eluate that must be evaporated prior to vitrification.

\subsection{Product Characterization}

Characterization results for the decontaminated product and the composited cesium and technetium eluate products are shown in Tables 13-16. In Table 13, the radionuclides, elemental compositions, and anion compounds in the decontaminated product solution are presented. The data for the decontaminated product represent only a portion (fractions \#1 and \#2 from the cesium ion exchange column experiment) of the total amount of Envelope B sample. In addition, the product sample is diluted $20 \%$ with $0.1 \mathrm{M} \mathrm{NaOH}$ solution from the cesium column preconditioning cycle. The concentrations of Cs-137 and Tc-99 in the decontaminated product sample were 6.5E-01 and $1.29 \mathrm{E}-4 \mu \mathrm{Ci} / \mathrm{mL}$, respectively. While the Cs concentration is higher than the target value, the Tc concentration in the product solution is well below the maximum radionuclide content allowed by the Immobilized Low-Activity Waste (ILAW) acceptance criteria. The percent removals for Cs-137 and Tc-99 were calculated from the area beneath the column breakthrough curves and the initial concentrations of Cs-137 or Tc-99 in the feed multiplied by the number of column volumes processed through the lead-guard column configuration. Removals of 98 and $99.97 \%$ were observed for Cs-137 and Tc-99, respectively. The chemical species in the final decontaminated product were lower in aluminum and calcium relative to the feed, but the total inorganic carbon and the total organic carbon both increased by $\sim 40 \%$. Inconsistency in the TIC/TOC analytical method has been observed previously, and it is not clear if the measurement reported here correctly reflects the composition. 
Inspection of the analysis results reported for the cesium eluate, shown in Tables 14 and 15, reveals that the eluate does not contain high levels of aluminum which might be expected if precipitation of aluminum solids occurred during column loading. It is also possible that $\mathrm{Al}$ solids remained in the resin pores during the acid elution and, consequently, $\mathrm{Al}$ was not observed in the eluate. The observation of a low [Al] in the eluate contrasts with the re-contact $\mathrm{K}_{\mathrm{d}}$ tests, which showed successively lower $\mathrm{Al}$ concentrations with repeated batch contact and filtration tests (Attachment 5). It should be noted however, that analysis of the cesium eluate solution initially gave inconsistent results in duplicate measurements, particularly regarding $\mathrm{Al}$ analysis. As shown, in Attachment 7, initial ICP-ES analysis indicated Al concentrations of $\sim 800$ and $<12 \mathrm{mg} / \mathrm{L}$ for duplicate samples when a 50:1 water dilution was used to lower the sample activity for analysis. Inconsistent eluate $\mathrm{Al}$ levels in duplicate analyses indicated that precipitation may have occurred due to dilution of the original $0.5 \mathrm{M} \mathrm{HNO}_{3}$ eluate sample with water. A second set of analyses was conducted using less dilution (1:20) in order to avoid Al precipitation. Inconsistent $\mathrm{Al}$ results were observed again, with concentrations reported for duplicate samples of 5 and $150 \mathrm{mg} / \mathrm{L} \mathrm{Al}$. A third set of samples was prepared by diluting the samples $(1: 30)$ with $0.5 \mathrm{M} \mathrm{HNO}_{3}$, rather than water. Analysis results in this case resulted in consistently low $\mathrm{Al}$ analysis $(\sim 2 \mathrm{mg} / \mathrm{L} \mathrm{Al})$ between duplicate samples (Table 15). In addition, samples of the guard column eluate which were diluted in the same manner and submitted for analysis showed very similar results (Attachment 8). Based solely on these results, aluminum precipitation appears not to have occurred, although the high $\mathrm{Al}$ observed for some of the eluate samples cannot be explained. High aluminum in the eluate would have been an indication of precipitation during column loading and might have explained the poor Cs column performance. It was thought that aluminum precipitation might have resulted from feed sample dilution during the early stages of column loading. A loss of $\sim 25 \%$ of the aluminum (after accounting for dilution) and $99 \%$ of the calcium from the feed concentration indicates that precipitation occurred. It should be emphasized that only ICP-ES and radiochemical analysis results were performed on the samples that were diluted 1:30 with acid (Table 15). The remaining analyses were performed on the original samples which were diluted 1:50 with water (Table 14). However, very consistent radionuclide analysis results were reported for the two dilutions.

Chloride ion concentration in the eluate varied considerably between the two analysis techniques used. Ion chromatography analysis indicated that chloride levels were $<100 \mathrm{mg} / \mathrm{L}$. In contrast, ion selective electrode (ISE) analysis indicated much higher chloride levels. The average of duplicate analyses by ISE was $4.93 \mathrm{E} 3 \mathrm{mg} / \mathrm{L}$, but considerable variance was observed between the duplicate samples $\left(\left[\mathrm{Cl}^{-}\right]\right.$range: $1.80 \mathrm{E} 3$ to $8.05 \mathrm{E} 3 \mathrm{mg} / \mathrm{L}$ ). A material balance calculation indicates that the chloride analyses are not self-consistent. The initial, final, and eluate samples contained 248, 180, and $4930 \mathrm{mg} / \mathrm{L}$ chloride, respectively. Based on the difference between the feed and product concentrations, the eluate could have contained no more than $505 \mathrm{mg} / \mathrm{L}$. These observations indicate that chloride anion may be concentrated by the cesium ion exchange resin, but analysis results with these complex mixtures are variable. Observations of high chloride ion concentration in SuperLig ${ }^{\circledR} 644$ cesium eluates were reported previously for 
ion exchange column experiments performed on other Hanford waste supernates. ${ }^{13,17}$ As reported previously, the cesium resin is also seen to concentrate and elute uranium.

Analysis results for the technetium eluate shown in Table 16 indicate the expected composition. However, the initial $\mathrm{Cl}^{-}$analyses results by ion chromatography (IC) were less than the method detection limit, whereas the $\mathrm{Cl}^{-}$results reported by ion selective electrode (ISE) averaged 1.03E-02 mg/L. Re-analysis of a Tc eluate sample with no dilution for $\mathrm{Cl}^{-}$by $\mathrm{IC}$ indicated an average concentration of $344 \mathrm{mg} / \mathrm{L}$. Inconsistency in $\mathrm{Cl}^{-}$analyses by IC and ISE have been noted in previous cesium and technetium eluate samples and is unexplained.

\subsection{CONCLUSIONS}

Cesium and technetium removal from Envelope B (Hanford Tank AZ-102) salt solution was accomplished using IBC-manufactured SuperLig ${ }^{\circledR}$ ion exchange resins. The cesium distribution coefficient for SuperLig ${ }^{\circledR} 644$ resin was $1685 \mathrm{~mL} / \mathrm{g}$. The projected volume of feed to process at $50 \%$ Cs breakthrough was estimated as 674 column volumes, although prior work indicated that only $37 \%$ of this value $(249 \mathrm{CV}$ ) would be reached. The resin achieved $\sim 45 \%$ Cs breakthrough after 89 column volumes of the feed sample was consumed. Nitric acid $(0.5 \mathrm{M})$ was effective to elute cesium from the resin with approximately $1 \%$ of the feed [Cs-137] in the eluate after 12.0 column volumes were eluted. The elution profile exhibited a small tailing effect. The percent removal of cesium from Envelope B (AZ-102) by the lead-guard column configuration containing SuperLig ${ }^{\circledR} 644$ resin was $98 \%$. This test did not verify the RPP-WTP design basis for treating the AZ-102 waste, which requires $99.83 \%$ removal of Cs-137 after processing a minimum of 50 column volumes of feed. The small-scale column test did confirm the RPP-WTP design basis for eluting the lead cesium ion exchange column.

Further work is needed in order to understand the poor performance of the cesium column. The evidence is strong, but not conclusive, that aluminum and calcium precipitated in the ion exchange resin beds, leading to poor performance. Plans for the pretreatment facility at Hanford include an option for using three cesium-removal columns in series, with the third column serving as a polishing column. Depending on the outcome of the planned testing, this third column may be needed for this waste type. Alternatively, if the poor performance was caused by resin swelling in this low ionic strength solution, the waste could be concentrated in the evaporator before filtration and ion exchange, as already planned during processing of this waste in the RPP-WTP. This would also have the benefit of improving the technetium ion exchange performance due to higher ionic strength, but would have the detrimental effect of increasing the radiation dose rate on the cesium column (although the total dose would be roughly equivalent). Another alternative is to recycle the Envelope B solution through the cesium ion exchange process to further reduce the Cs-137 concentration. A complete evaluation of the benefits and risks is needed to determine the best option. 
WSRC-TR-2000-00419

SRT-RPP-2000-00036 Revision 0

The distribution coefficient $\left(K_{d}\right.$ value) for technetium on SuperLig ${ }^{\circledR} 639$ resin was $883 \mathrm{~mL} / \mathrm{g}$. The projected number of column volumes to process to reach $50 \% \mathrm{Tc}$ breakthrough was 415 . Less than $10 \%$ breakthrough of the technetium was observed through the lead column after processing 170 column volumes, and the guard column maintained $\sim 0.04 \%$ breakthrough during the entire experiment. Elution of technetium from the resin with de-ionized water $\left(25^{\circ} \mathrm{C}\right)$ at $1 \mathrm{CV} / \mathrm{hr}$ was not efficient, with $96 \% \mathrm{Tc}$ recovery up to 20 column volumes and $\sim 8 \%$ of the feed Tc concentration remaining in the eluate after 34 column volumes. The percent removal of technetium from the small portion of the Envelope B (Hanford AZ-102) sample tested was 99.97\%. This high percentage removal for Tc-99 suggests that the technetium ion exchange columns performed better than previous samples. This may be attributed to the low nitrate to technetium ratio in this sample. This small-scale column test confirms the RPP-WTP design basis for minimum Tc-99 removal and volume of waste solution processed for the AZ-102 sample. However, the elution volume was greater than the RPP-WTP design basis. Further tests are needed to evaluate methods to reduce the eluate volume, such as using water at 60 to $70{ }^{\circ} \mathrm{C}$.

Characterization results showed that the $\mathrm{Cs} / \mathrm{Na}$ and $\mathrm{Tc} / \mathrm{Na}$ mole ratios in the final decontaminated LAW product were 3.63E-4 Ci/mole $\mathrm{Na}$ and 7.21E-08 Ci/mole Na, respectively. Some dilution of the product occurred during the ion exchange processing, with a final $\left[\mathrm{Na}^{+}\right]$of $2.21 \mathrm{M}$ (based on AA analysis). Per US DOE contract specification (2.2.2.8), the average concentrations of Cs-137, Sr-90, and Tc-99 in the vitrified LowActivity Waste are limited to less than 3,20 , and $0.1 \mathrm{Ci} / \mathrm{m}^{3}$, respectively. ${ }^{4}$ The average concentrations are calculated by summing the actual inventories of each of the above radionuclides in waste packages and dividing by the total volume of waste in these packages. Thus, a minimum of $80 \%$ removal of the Tc-99 present in the feed from AZ102 was required. The radionuclide content in the decontaminated product would result in glass containing far lower Tc than the limits for the ILAW glass. The overall chemical composition of the final decontaminated product was as expected. 


\subsection{QUALITY ASSURANCE}

This work fulfills the requirements in the following Task Plan for the sample from tank 241-AZ-102: BNF-003-98-0050, Hanford Tank Waste Small-Scale Ion Exchange Study Task Technical and Quality Assurance Plan (U), D. J. McCabe, January 15, 1999. All equipment was calibrated and all work was conducted as specified in the QA Plan.

\subsection{REFERENCES}

1. Hassan, N. M., McCabe, D. J., and King, W. D., Small-Scale Ion Exchange Removal of Cesium and Technetium from Hanford Tank 241-AN-103, BNF-00398-0146, Revision 0.

2. Hassan, N. M. and McCabe D. J., Hanford Envelope B Tank Waste Ion Exchange Column Study (U), SRTC-BNFL-019, Revision 0, October 24, 1997.

3. System Description for Cesium Removal Using Ion Exchange: PT-330, SDW375PT-PR00002, Revision 3, CH2MHill Hanford Group Inc., Richland Washington, October 2, 2000.

4. USDOE Contract No. DE-AC27-96RV13308 (formerly contract no. DE-AC0696RL13308), Specification 2: Immobilized Low-Activity Waste.

5. Letter number CCN\# 016099C from M. E. Johnson to S. M. Mackay, CH2MHill Hanford Group Inc., Technetium Removal Requirements, dated October 25, 2000.

6. System Description for Technetium Removal Using Ion Exchange: LP-330, SDW375LP-PR00007, Revision 1, CH2MHill Hanford Group Inc., Richland Washington, October 2, 2000.

7. Tank Waste Remediation System (TWRS) Privatization Contract Samples Waste Envelope B Material 241-AN-105, HNF-SD-WM-DP-218, Revision 0A, R. A. Esch, Rust Federal Services of Hanford Inc., Richland, Washington, 1997.

8. Ion Exchange Test Specification, TSP-W375-99-00013, Revision 3, BNFL Inc., Richland Washington, September 28, 1999.

9. Hamm, L. L. Preliminary Ion Exchange Modeling for Removal of Cesium from Hanford Waste Using SuperLig ${ }^{\circledR} 644$ Resin, BNF-003-98-0220, Westinghouse Savannah River Company, Aiken, South Carolina, June 16, 2000. 
WSRC-TR-2000-00419

SRT-RPP-2000-00036 Revision 0

10. Hay, M., Chemical Characterization of an Envelope B Sample from Hanford Tank 241-AZ-102, BNF-003-98-0249, Westinghouse Savannah River Company, June 2000.

11. McCabe, D. J, Hassan, N. M. and Thompson, M. C., $\underline{\text { SuperLig }{ }^{\circledR} 644 \text { Pretreatment }}$ Requirement for Hanford Privatization Samples (U), SRTC-BNFL-012, Revision 0, July 21, 1997.

12. Hassan, N. M, King, W. D., and McCabe, D. J, SuperLig ${ }^{\circledR}$ Ion Exchange Resin Swelling and Buoyancy Study (U), BNF-003-98-0051, Revision 0.

13. Hassan, N. M, McCabe, D. J. and King, W. D., Small-scale Ion exchange Removal of Cesium and Technetium from Hanford Tank 241-AN-102, BNF-00398-0219, December, 1999.

14. Hamm, L. L. Preliminary Ion Exchange Modeling for Removal of Technetium from Hanford Waste Using SuperLig ${ }^{\circledR} 639$ Resin, WSRC-TR-2000-00305, SRTRPP-2000-00011, Westinghouse Savannah River Company, Aiken, South Carolina, August 2000.

15. Bray, L. A. Efficient Separations and Processing Crosscutting Program: Develop and Test Sorbents, PNL-10750, Pacific Northwest Laboratory, September 1995.

16. King, W. D., Hassan, N. M, and McCabe, D. J, Optimization of Cesium Removal from Hanford Envelope A Simulant with SuperLig ${ }^{\circledR} 644$ Ion Exchange Resin, BNF-003-98-0169, Revision 0.

17. King, W. D., McCabe, D. J., and Hassan, N. M, Intermediate-scale Ion exchange Removal of Cesium and Technetium from Hanford Tank 241-AN-102, BNF-00398-0244, Revision 0. 
Table 1. Envelope B (AZ-102) Filtrate Characterization Data

\begin{tabular}{|c|c|c|}
\hline Constituent ions & $\begin{array}{c}\text { Tank-241-AZ-102 } \\
\text { concentration }\end{array}$ & $\begin{array}{c}\text { Tank-241-AZ-102 } \\
\text { concentration }\end{array}$ \\
\hline Cations & $\mathbf{M}$ & $\mathrm{mg} / \mathrm{L}$ \\
\hline$\left[\mathrm{Na}^{+}\right]$ & 2.65 & $6.37 \mathrm{E}+04$ \\
\hline$[\mathrm{Al}]$ & $2.79 \mathrm{E}-02$ & $7.53 \mathrm{E}+02$ \\
\hline [Ca] & $2.70 \mathrm{E}-03$ & $1.08 \mathrm{E}+02$ \\
\hline$[\mathrm{Cr}]$ & $1.48 \mathrm{E}-02$ & $7.68 \mathrm{E}+02$ \\
\hline$[\mathrm{Pb}]$ & $<3.98 \mathrm{E}-05$ & $<8.25 \mathrm{E}+02$ \\
\hline$[\mathrm{Zn}]$ & $<1.53 \mathrm{E}-05$ & $<1.00 \mathrm{E}+02$ \\
\hline$\left[\mathrm{K}^{+}\right]$ & $8.10 \mathrm{E}-02$ & $3.15 \mathrm{E}+03$ \\
\hline U - Chem Chek & $2.24 \mathrm{E}-05$ & $5.33 \mathrm{E}+00$ \\
\hline $\mathrm{U} \& \mathrm{Pu}-\operatorname{mass} 238$ & $2.92 \mathrm{E}-05$ & $6.94 \mathrm{E}+00$ \\
\hline \multicolumn{3}{|l|}{ Anions } \\
\hline$\left[\mathrm{NO}_{3}^{-}\right]$ & $2.73 \mathrm{E}-01$ & $1.69 \mathrm{E}+04$ \\
\hline$\left[\mathrm{NO}_{2}{ }_{2}^{-}\right]$ & $8.32 \mathrm{E}-01$ & $3.83 \mathrm{E}+04$ \\
\hline$\left[\mathrm{SO}_{4}^{-2}\right]$ & $1.72 \mathrm{E}-01$ & $1.65 \mathrm{E}+04$ \\
\hline$\left[\mathrm{PO}_{4}^{-2}\right]$ & $<3.0 \mathrm{E}-03$ & $<2.85 \mathrm{E}+02$ \\
\hline Oxalate & $3.21 \mathrm{E}-02$ & $2.83 \mathrm{E}+03$ \\
\hline formate & $<6.00 \mathrm{E}-03$ & $<2.70 \mathrm{E}+02$ \\
\hline$\left[\mathrm{Cl}^{-}\right]$, by IC & $<1.00 \mathrm{E}-03$ & $<3.55 \mathrm{E}+01$ \\
\hline$\left[\mathrm{F}^{-}\right]$, by IC & $5.09 \mathrm{E}-02$ & $9.67 \mathrm{E}+02$ \\
\hline$\left[\mathrm{Cl}^{-}\right]$, by ISE & $7.00 \mathrm{E}-03$ & $2.48 \mathrm{E}+02$ \\
\hline$\left[\mathrm{F}^{-}\right]$, by ISE & $5.34 \mathrm{E}-02$ & $1.01 \mathrm{E}+03$ \\
\hline $\mathrm{OH}^{-}$(Free) & $1.09 \mathrm{E}-01$ & $1.85 \mathrm{E}+03$ \\
\hline \multicolumn{3}{|l|}{ Total carbon } \\
\hline TIC & $5.11 \mathrm{E}-01$ & --- \\
\hline TOC & $5.03 \mathrm{E}-01$ & --- \\
\hline Radionuclides & $\mu \mathrm{Ci} / \mathrm{mL}$ & \\
\hline Cs-137 & $1.14 \mathrm{E}+03$ & \\
\hline Am-241 & $<1.64 \mathrm{E}-02$ & \\
\hline Sr-90 & $2.07 \mathrm{E}+00$ & \\
\hline Tc (calc'd, mass 99 ) & $2.67 \mathrm{E}-01$ & \\
\hline & $\mathrm{g} / \mathrm{mL}$ & \\
\hline Density & $1.15 \mathrm{E}+00$ & \\
\hline
\end{tabular}


Table 2. Physical Properties of "As-received" SuperLig ${ }^{\circledR} 644$ and 639 Resins

\begin{tabular}{|l|c|c|c|c|c|}
\hline Resin & Batch \# & $\begin{array}{c}\text { Particle } \\
\text { density }(\mathrm{g} / \mathrm{mL})\end{array}$ & $\begin{array}{c}\text { Bulk density } \\
(\mathrm{g} / \mathrm{mL})\end{array}$ & $\begin{array}{c}\text { \% Water } \\
\text { content }\end{array}$ & F-Factor \\
\hline SuperLig $^{\circledR} 644$ & $981020 \mathrm{MB} 48-563$ & 1.549 & 0.758 & 9.6 & 0.904 \\
\hline SuperLig $^{\circledR} 639$ & $981015 \mathrm{DHC}-720011$ & 1.147 & 0.468 & 1.3 & 0.987 \\
\hline
\end{tabular}

Table 3. Sieve Analysis of SuperLig ${ }^{\circledR} 639$ Resin Batch \#981015DHC-720011

\begin{tabular}{|c|c|c|c|c|c|c|}
\hline & & \multicolumn{2}{|c|}{ wt. of fractions (g) } & \multicolumn{2}{|c|}{ wt. \% } & avg. wt. \% \\
\hline Screen Mesh & Opening & Sample 1 & Sample 2 & Sample 1 & Sample 2 & $(\%)$ \\
\hline 10 & $>2.00 \mathrm{~mm}$ & & & & & \\
\hline 30 & $>600 \mu \mathrm{m}$ & 4.37 & 4.169 & 87.35 & 83.25 & 85.30 \\
\hline 40 & $>425$ & 0.574 & 0.722 & 11.47 & 14.42 & 12.95 \\
\hline 50 & $>300$ & 0.035 & 0.054 & 0.70 & 1.078 & 0.889 \\
\hline 70 & $>212$ & 0.01 & & 0.20 & & 0.10 \\
\hline 80 & $>180$ & 0.007 & & & & \\
\hline 100 & $>150$ & & & & & \\
\hline 230 & $>62$ & & & & & \\
\hline \multicolumn{2}{|c|}{ total } & 5.00 & 4.945 & 99.7 & 98.7 & 99.2 \\
\hline
\end{tabular}

wt. original sample \#1 = $5.003 \mathrm{~g}$; wt. original sample \#2=5.008 g

Table 4. Sieve Analysis of SuperLig ${ }^{\circledR} 644$ Resin Batch \#981020mb48-563

\begin{tabular}{|c|c|c|c|c|c|c|}
\hline & & \multicolumn{2}{|c|}{ wt. of fractions $(\mathrm{g})$} & \multicolumn{2}{|c|}{ wt. \% } & avg. wt. \% \\
\hline Screen Mesh & Opening & Sample 1 & Sample 2 & Sample 1 & Sample 2 & $(\%)$ \\
\hline 10 & $>2.00 \mathrm{~mm}$ & 0 & 0 & 0 & & 0 \\
\hline 30 & $>600 \mu \mathrm{m}$ & 2.9342 & 2.8406 & 59.77 & 54.89 & 57.33 \\
\hline 40 & $>425$ & 1.1143 & 1.2821 & 22.70 & 24.77 & 23.73 \\
\hline 50 & $>300$ & 0.6389 & 0.7456 & 13.01 & 14.41 & 13.71 \\
\hline 70 & $>212$ & 0.2115 & 0.3072 & 4.31 & 5.94 & 5.12 \\
\hline 80 & $>180$ & 0.0105 & 0 & 0.21 & 0.00 & 0.11 \\
\hline 100 & $>150$ & & & & & \\
\hline 230 & $>62$ & & & & & \\
\hline & total & 4.9094 & 5.1755 & 99.8 & 100 & 99.9 \\
\hline
\end{tabular}

wt. original sample \#1 = 5.003 g; wt. original sample \#2 $=5.1758 \mathrm{~g}$ 
Table 5. Batch Distribution Coefficient Data for Cs-137 on SuperLig ${ }^{\circledR} 644$ Resin

\begin{tabular}{|l|c|c|c|c|c|c|c|c|c|}
\hline Sample ID & $\begin{array}{c}\text { solution } \\
\text { mass }(\mathrm{g})\end{array}$ & $\begin{array}{c}\text { resin mass, } \\
\mathrm{M}(\mathrm{g})\end{array}$ & $\begin{array}{c}\text { density, } \rho \\
(\mathrm{g} / \mathrm{mL})\end{array}$ & $\begin{array}{c}\text { phase ratio } \\
\text { ratio, V/M } \\
(\mathrm{mL} / \mathrm{g})\end{array}$ & $\begin{array}{c}{[\mathrm{Cs}-137],} \\
\mathrm{C}_{\mathrm{e}} \text { or } \mathrm{C}_{\mathrm{i}} \\
(\mu \mathrm{Ci} / \mathrm{mL})\end{array}$ & $\begin{array}{c}{[\mathrm{Cs}-137]} \\
\text { removed, } \mathrm{C}_{\mathrm{i}}-\mathrm{C}_{\mathrm{e}} \\
(\mu \mathrm{Ci} / \mathrm{mL})\end{array}$ & $\begin{array}{c}\mathrm{K}_{\mathrm{d}} \\
(\mathrm{mL} / \mathrm{g})\end{array}$ & $\begin{array}{c}\text { avg. } \mathrm{K}_{\mathrm{d}} \\
(\mathrm{mL} / \mathrm{g})\end{array}$ & $(\% \mathrm{R})$ \\
\hline Standard K & & & & & & & & & \\
\hline BNF-B305-S644-1 & 20.878 & 0.1804 & 1.15 & 101 & 60.43 & $937 . .8$ & 1728 & & \\
\hline BNF-B305-S644-1D & 20.308 & 0.1806 & 1.15 & 97.8 & 61.67 & 936.6 & 1643 & 1685 & 93.9 \\
\hline BNF-B305-AZ102-1 & 20.438 & na & 1.15 & na & 1008 & & & & \\
\hline BNF-B305-AZ102-2 & 20.473 & na & 1.15 & na & 989 & & & & \\
\hline $\mathbf{I}^{\text {st }}$ Re-contact & & & & & & & & & \\
\hline BNF-B305-S644-1R-1 & 12.299 & 0.1208 & 1.15 & 88.5 & 2.943 & 57.48 & 1913 & & \\
\hline BNF-B305-S644-1R-1D & 12.223 & 0.1202 & 1.15 & 88.4 & 3.159 & 58.51 & 1812 & 1862 & 95.0 \\
\hline $\mathbf{2}^{\text {nd }}$ Re-contact & & & & & & & & & \\
\hline BNF-B305-S644-2R-1 & 8.598 & 0.1008 & 1.15 & 74.2 & 0.205 & 2.738 & 1094 & & \\
\hline BNF-B305-S644-2R-1D & 8.809 & 0.1009 & 1.15 & 75.9 & 0.308 & 2.851 & 776.9 & 935.6 & 91.6 \\
\hline
\end{tabular}

F-factor $=0.904$; Temperature $=26 \pm 1^{\circ} \mathrm{C}$; contact time $=24 \pm 1 \mathrm{hr}$; batch \#: 981020MB48-563; avg $\mathrm{C}_{\mathrm{i}}=$ $998.2 \mu \mathrm{Ci} / \mathrm{mL}$. na $=$ not applicable

\section{Table 6. Batch Distribution Coefficient Data for Tc-99 on SuperLig ${ }^{\circledR} 639$ Resin}

\begin{tabular}{|l|c|c|c|c|c|c|c|c|c|}
\hline Sample ID & $\begin{array}{c}\text { solution } \\
\text { mass }(\mathrm{g})\end{array}$ & $\begin{array}{c}\text { resin mass, } \\
\mathrm{M}(\mathrm{g})\end{array}$ & $\begin{array}{c}\text { density, } \rho \\
(\mathrm{g} / \mathrm{mL})\end{array}$ & $\begin{array}{c}\text { phase ratio } \\
\text { ratio, V/M } \\
(\mathrm{mL} / \mathrm{g})\end{array}$ & $\begin{array}{c}{[\mathrm{Tc}-99],} \\
\mathrm{C}_{\mathrm{e}} \text { or } \mathrm{C}_{\mathrm{i}} \\
(\mu \mathrm{g} / \mathrm{L})\end{array}$ & $\begin{array}{c}{[\mathrm{Tc}-99]} \\
\text { removed, } \mathrm{C}_{\mathrm{i}}-\mathrm{C}_{\mathrm{e}} \\
(\mu \mathrm{g} / \mathrm{L})\end{array}$ & $\begin{array}{c}\mathrm{K}_{\mathrm{d}} \\
(\mathrm{mL} / \mathrm{g})\end{array}$ & $\begin{array}{c}\text { avg. } \mathrm{K}_{\mathrm{d}} \\
(\mathrm{mL} / \mathrm{g})\end{array}$ & $(\% \mathrm{R})$ \\
\hline Standard K & & & & & & & & \\
\hline BNF-B305-S639-1 & 20.559 & 0.1808 & 1.15 & 98.9 & 1378 & 12499 & 908.6 & & \\
\hline BNF-B305-S639-1D & 20.624 & 0.1801 & 1.15 & 99.6 & 1461 & 12416 & 857.4 & 883.0 & 89.8 \\
\hline BNF-B305-AZ102-1 & 20.438 & na & 1.15 & na & 13966 & & & & \\
\hline BNF-B305-AZ102-1D & 20.473 & na & 1.15 & na & 13788 & & & & \\
\hline $\mathbf{1}^{\text {st }}$ Re-contact & & & & & & & & & \\
\hline BNF-B305-S639-1R-1 & 12.239 & 0.1212 & 1.15 & 87.8 & 136 & 1242 & 811.7 & & \\
\hline BNF-B305-S639-1R-D & 12.357 & 0.1209 & 1.15 & 88.9 & 111 & 1349 & 1090 & 950.9 & 91.2 \\
\hline $\mathbf{2}^{\text {nd }}$ Re-contact & & & & & & & & & \\
\hline BNF-B305-S639-2R-1 & 8.426 & 0.1005 & 1.15 & 72.9 & 15.55 & 120.6 & 572.6 & & \\
\hline BNF-B305-S639-2R-D & 9.018 & 0.1007 & 1.15 & 77.9 & 24.04 & 87.44 & 287.0 & 429.8 & 83.5 \\
\hline $\mathbf{3}^{\text {rd } \text { Re-contact }}$ & & & & & & & & & \\
\hline BNF- B305-S639-3R-1 & 4.915 & 0.0526 & 1.15 & 81.3 & 4.292 & 11.26 & 216.0 & & \\
\hline BNF- B305-S639-3R-1D & 4.212 & 0.0512 & 1.15 & 71.5 & 6.596 & 17.44 & 191.7 & 203.8 & 72.48 \\
\hline
\end{tabular}

F-factor $=0.987$; Temperature $=26 \pm 1{ }^{\circ} \mathrm{C}$; contact time $=24 \pm 1 \mathrm{hr}$; batch \#: 981015DHC-720011; avg $\mathrm{C}_{\mathrm{i}}=$ $13877 \mu \mathrm{g} / \mathrm{L}$ 
Table 7. Cesium Ion Exchange Column Loading Profiles (Lead/Guard Columns)

\begin{tabular}{|l|c|c|c|}
\hline Lead column sample ID & \# CV processed & Cs-137 $(\boldsymbol{\mu C i} / \mathbf{m L})$ & Concentration profile (C/Co) \\
\hline BNF-3-B315-NB99-23-FD & na & $1.07 \mathrm{E}+03$ & na \\
\hline BNF-3-B315-NB99-23-LC-FS-1 & 9.9 & $1.20 \mathrm{E}+01$ & $1.12 \mathrm{E}-02$ \\
\hline BNF-3-B315-NB99-23-LC-FS-2 & 17.1 & $5.50 \mathrm{E}+01$ & $5.16 \mathrm{E}-02$ \\
\hline BNF-3-B315-NB99-23-LC-FS-3 & 25.2 & $1.19 \mathrm{E}+02$ & $1.11 \mathrm{E}-01$ \\
\hline BNF-3-B315-NB99-23-LC-FS-4 & 33.7 & $1.43 \mathrm{E}+02$ & $1.34 \mathrm{E}-01$ \\
\hline BNF-3-B315-NB99-23-LC-FS-5 & 42.4 & $3.15 \mathrm{E}+02$ & $2.95 \mathrm{E}-01$ \\
\hline BNF-3-B315-NB99-23-LC-FS-6 & 50.8 & $2.89 \mathrm{E}+02$ & $2.71 \mathrm{E}-01$ \\
\hline BNF-3-B315-NB99-23-LC-FS-7 & 59.4 & $3.56 \mathrm{E}+02$ & $3.34 \mathrm{E}-01$ \\
\hline BNF-3-B315-NB99-23-LC-FS-8 & 68.0 & $4.35 \mathrm{E}+02$ & $4.08 \mathrm{E}-01$ \\
\hline BNF-3-B315-NB99-23-LC-FS-9 & 76.6 & $4.88 \mathrm{E}+02$ & $4.58 \mathrm{E}-01$ \\
\hline BNF-3-B315-NB99-23-LC-FS-10 & 89.1 & $4.76 \mathrm{E}+02$ & $4.47 \mathrm{E}-01$ \\
\hline Guard column sample ID & & & $7.50 \mathrm{E}-05$ \\
\hline BNF-3-B315-NB99-23-GC-FS-2 & 17.9 & $8.00 \mathrm{E}-02$ & $1.27 \mathrm{E}-03$ \\
\hline BNF-3-B315-NB99-23-GC-FS-4 & 31.7 & $1.35 \mathrm{E}+00$ & $8.93 \mathrm{E}-03$ \\
\hline BNF-3-B315-NB99-23-GC-FS-6 & 48.3 & $9.52 \mathrm{E}+00$ & $3.66 \mathrm{E}-02$ \\
\hline BNF-3-B315-NB99-23-GC-FS-8 & 64.8 & $3.90 \mathrm{E}+01$ & $8.44 \mathrm{E}-02$ \\
\hline BNF-3-B315-NB99-23-GC-FS-9 & 86.5 & $9.00 \mathrm{E}+01$ & $8.91 \mathrm{E}-02$ \\
\hline BNF-3-B315-NB99-23-GC-FS-10 & 88.9 & $9.50 \mathrm{E}+01$ & \\
\hline
\end{tabular}

Table 8. SuperLig ${ }^{\circledR} 644$ Column Wash and Regenerate Solution Characterization

\begin{tabular}{|c|c|c|c|c|c|c|c|c|}
\hline Sample & ADS \# & CV per Bottle & $\begin{array}{c}\text { Cs-137 } \\
(\mu \mathrm{Ci} / \mathrm{mL})\end{array}$ & $\begin{array}{l}\mathrm{Na}^{+} \\
(\mathrm{M})\end{array}$ & $\begin{array}{l}\text { Free } \mathrm{OH}^{-} \\
\text {(M) }\end{array}$ & $\begin{array}{l}\text { Total } \mathrm{OH}^{-} \\
\text {(M) }\end{array}$ & Collection Port & $\begin{array}{l}\% \text { of Total Cs } 137 \\
\text { in Column Feed }\end{array}$ \\
\hline Fraction 1 & 300143599 & 1.2 & $1.26 \mathrm{E}+02$ & 2.65 & 0.078 & 0.594 & Guard Column & $0.16 \%$ \\
\hline Fraction 2 & 300143600 & 1.2 & $1.30 \mathrm{E}+02$ & 2.66 & 0.114 & 0.582 & Guard Column & $0.16 \%$ \\
\hline Fraction 3 & 300143601 & 1.2 & $1.11 \mathrm{E}+02$ & 2.36 & 0.151 & 0.585 & Guard Column & $0.14 \%$ \\
\hline Fraction 4 & 300143521 & 1.2 & $3.11 \mathrm{E}+01$ & 0.55 & 0.178 & 0.215 & Lead Column & $0.04 \%$ \\
\hline Fraction 5 & 300143522 & 1.2 & $2.93 \mathrm{E}+02$ & 0.04 & 0.037 & 0.012 & Lead Column & $0.37 \%$ \\
\hline \multirow[t]{2}{*}{ Column Regenerate } & 300143598 & $6^{*}$ & $2.05 \mathrm{E}-01$ & 0.03 & $<0.02$ & NA & Lead Column & $0.04 \%$ \\
\hline & & & & & & & Total & $0.87 \%$ \\
\hline
\end{tabular}

*The size of one column volume for the regenerate solution increased from 32 to $107 \mathrm{~mL}$ due to the addition of more SuperLig ${ }^{\circledR} 644$ resin to the columns in preparation for the next experiment.

Table 9. Cesium Ion Exchange Column Elution Profile (Lead Column)

\begin{tabular}{|c|c|c|c|}
\hline Lead column sample ID & $\begin{array}{c}\text { \# CV eluted } \\
(\text { lead column })\end{array}$ & $\begin{array}{c}\text { Cs in eluate } \\
(\boldsymbol{\mu C i} \mathbf{m L})\end{array}$ & $\begin{array}{c}\text { Concentration } \\
\text { profile }(\mathbf{C} / \mathbf{C o})\end{array}$ \\
\hline BNF-3-B315-NB99-230-LC-ES-1 & 1.4 & $1.84 \mathrm{E}+01$ & $1.72 \mathrm{E}-02$ \\
\hline BNF-3-B315-NB99-230-LC-ES-2 & 2.9 & $2.09 \mathrm{E}+04$ & $1.96 \mathrm{E}+01$ \\
\hline BNF-3-B315-NB99-230-LC-ES-3 & 4.8 & $2.86 \mathrm{E}+04$ & $2.68 \mathrm{E}+01$ \\
\hline BNF-3-B315-NB99-230-LC-ES-4 & 6.6 & $6.73 \mathrm{E}+02$ & $6.31 \mathrm{E}-01$ \\
\hline BNF-3-B315-NB99-230-LC-ES-5 & 8.4 & $7.96 \mathrm{E}+01$ & $7.47 \mathrm{E}-02$ \\
\hline BNF-3-B315-NB99-230-LC-ES-6 & 10.3 & $2.03 \mathrm{E}+01$ & $1.90 \mathrm{E}-02$ \\
\hline BNF-3-B315-NB99-230-LC-ES-7 & 12.0 & $1.20 \mathrm{E}+01$ & $1.13 \mathrm{E}-02$ \\
\hline
\end{tabular}


WSRC-TR-2000-00419

SRT-RPP-2000-00036 Revision 0

Table 10. Technetium Ion Exchange Column Loading Profile (Lead Column)

\begin{tabular}{|l|c|c|c|}
\hline Lead column sample ID & $\begin{array}{c}\text { \# CV fed to } \\
\text { lead column }\end{array}$ & $\begin{array}{c}\text { Tc-99 Effluent } \\
(\mu \mathrm{g} / \mathrm{L})\end{array}$ & $\begin{array}{c}\text { Concentration } \\
\text { profile }(\mathrm{C} / \mathrm{Co})\end{array}$ \\
\hline BNF-B310-TcIX-Feed-1 & na & $1.26 \mathrm{E}+04$ & na \\
\hline BNF-B310-TcIX-Feed-2 & na & $1.36 \mathrm{E}+04$ & na \\
\hline BNF-B310-TcIXEFF-Cr5-LCS1 & 5 & $3.20 \mathrm{E}+00$ & $2.44 \mathrm{E}-04$ \\
\hline BNF-B310-TcIXEFF-Cr5-LCS2 & 10 & $5.09 \mathrm{E}+01$ & $3.88 \mathrm{E}-03$ \\
\hline BNF-B310-TcIXEFF-Cr5-LCS3 & 20 & $3.33 \mathrm{E}+01$ & $2.54 \mathrm{E}-03$ \\
\hline BNF-B310-TcIXEFF-Cr5-LCS4 & 30 & $4.80 \mathrm{E}+01$ & $3.66 \mathrm{E}-03$ \\
\hline BNF-B310-TcIXEFF-Cr5-LCS5 & 40 & $8.78 \mathrm{E}+01$ & $6.69 \mathrm{E}-03$ \\
\hline BNF-B310-TcIXEFF-Cr5-LCS6 & 50 & $8.97 \mathrm{E}+01$ & $6.83 \mathrm{E}-03$ \\
\hline BNF-B310-TcIXEFF-Cr5-LCS7 & 60 & $1.40 \mathrm{E}+02$ & $1.07 \mathrm{E}-02$ \\
\hline BNF-B310-TcIXEFF-Cr5-LCS8 & 70 & $3.14 \mathrm{E}+02$ & $2.39 \mathrm{E}-02$ \\
\hline BNF-B310-TcIXEFF-Cr5-LCS9 & 80 & $3.17 \mathrm{E}+02$ & $2.42 \mathrm{E}-02$ \\
\hline BNF-B310-TcIXEFF-Cr5-LCS10 & 90 & $3.49 \mathrm{E}+02$ & $2.66 \mathrm{E}-02$ \\
\hline BNF-B310-TcIXEFF-Cr5-LCS11 & 100 & $3.80 \mathrm{E}+02$ & $2.89 \mathrm{E}-02$ \\
\hline BNF-B310-TcIXEFF-Cr5-LCS12 & 110 & $4.43 \mathrm{E}+02$ & $3.37 \mathrm{E}-02$ \\
\hline BNF-B310-TcIXEFF-Cr5-LCS13 & 120 & $4.60 \mathrm{E}+02$ & $3.50 \mathrm{E}-02$ \\
\hline BNF-B310-TcIXEFF-Cr5-LCS14 & 130 & $5.60 \mathrm{E}+02$ & $4.26 \mathrm{E}-02$ \\
\hline BNF-B310-TcIXEFF-Cr5-LCS15 & 140 & $6.84 \mathrm{E}+02$ & $5.20 \mathrm{E}-02$ \\
\hline BNF-B310-TcIXEFF-Cr5-LCS16 & 150 & $8.44 \mathrm{E}+02$ & $6.42 \mathrm{E}-02$ \\
\hline BNF-B310-TcIXEFF-Cr5-LCS17 & 160 & $1.02 \mathrm{E}+03$ & $7.80 \mathrm{E}-02$ \\
\hline BNF-B310-TcIXEFF-Cr5-LCS18 & 170 & $1.26 \mathrm{E}+03$ & $9.60 \mathrm{E}-02$ \\
\hline
\end{tabular}

Table 11. Technetium Ion Exchange Column Loading Profile (Guard Column)

\begin{tabular}{|l|c|c|c|}
\hline Lead column sample ID & $\begin{array}{c}\text { \# CV fed to } \\
\text { guard column }\end{array}$ & $\begin{array}{c}\text { Tc-99 Effluent } \\
(\mu \mathrm{g} / \mathrm{L})\end{array}$ & $\begin{array}{c}\text { Concentration } \\
\text { profile }(\mathrm{C} / \mathrm{Co})\end{array}$ \\
\hline BNF-B310-TcIXEFF-Cr5-GCVS1 & 9 & $3.200 \mathrm{E}+00$ & $2.44 \mathrm{E}-04$ \\
\hline BNF-B310-TcIXEFF-Cr5-GCVS2 & 22 & $3.900 \mathrm{E}+00$ & $2.97 \mathrm{E}-04$ \\
\hline BNF-B310-TcIXEFF-Cr5-GCVS3 & 33 & $3.200 \mathrm{E}+00$ & $2.44 \mathrm{E}-04$ \\
\hline BNF-B310-TcIXEFF-Cr5-GCVS4 & 51 & $5.520 \mathrm{E}+00$ & $4.20 \mathrm{E}-04$ \\
\hline BNF-B310-TcIXEFF-Cr5-GCVS5 & 63 & $4.940 \mathrm{E}+00$ & $3.76 \mathrm{E}-04$ \\
\hline BNF-B310-TcIXEFF-Cr5-GCVS6 & 76 & $4.700 \mathrm{E}+00$ & $3.58 \mathrm{E}-04$ \\
\hline BNF-B310-TcIXEFF-Cr5-GCVS7 & 90 & $5.980 \mathrm{E}+00$ & $4.55 \mathrm{E}-04$ \\
\hline BNF-B310-TcIXEFF-Cr5-GCVS8 & 104 & $3.200 \mathrm{E}+00$ & $2.44 \mathrm{E}-04$ \\
\hline BNF-B310-TcIXEFF-Cr5-GCVS9 & 118 & $3.200 \mathrm{E}+00$ & $2.44 \mathrm{E}-04$ \\
\hline BNF-B310-TcIXEFF-Cr5-GCVS10 & 127 & $3.480 \mathrm{E}+00$ & $2.65 \mathrm{E}-04$ \\
\hline
\end{tabular}


Table 12. Technetium Ion Exchange Column Elution Profile (Lead Column)

\begin{tabular}{|l|c|c|c|}
\hline Lead column Sample ID & $\begin{array}{c}\text { \# CV eluate } \\
\text { (lead column })\end{array}$ & $\begin{array}{c}\text { Tc-99 eluted } \\
(\mu \mathrm{g} / \mathrm{L})\end{array}$ & $\begin{array}{c}\text { Concentration } \\
\text { profile }(\mathrm{C} / \mathrm{Co})\end{array}$ \\
\hline BNF-B310-TcIXElu-Cr5-LCS1 & 2.42 & $4.90 \mathrm{E}+03$ & $3.73 \mathrm{E}-01$ \\
\hline BNF-B310-TcIXElu-Cr5-LCS2 & 4.27 & $5.68 \mathrm{E}+03$ & $4.33 \mathrm{E}-01$ \\
\hline BNF-B310-TcIXElu-Cr5-LCS3 & 6.36 & $1.17 \mathrm{E}+04$ & $8.93 \mathrm{E}-01$ \\
\hline BNF-B310-TcIXElu-Cr5-LCS4 & 8.20 & $2.93 \mathrm{E}+04$ & $2.23 \mathrm{E}+00$ \\
\hline BNF-B310-TcIXElu-Cr5-LCS5 & 10.34 & $1.18 \mathrm{E}+05$ & $9.01 \mathrm{E}+00$ \\
\hline BNF-B310-TcIXElu-Cr5-LCS6 & 11.95 & $2.48 \mathrm{E}+05$ & $1.89 \mathrm{E}+01$ \\
\hline BNF-B310-TcIXElu-Cr5-LCS7 & 13.89 & $1.71 \mathrm{E}+05$ & $1.31 \mathrm{E}+01$ \\
\hline BNF-B310-TcIXElu-Cr5-LCS8 & 15.81 & $8.66 \mathrm{E}+04$ & $6.59 \mathrm{E}+00$ \\
\hline BNF-B310-TcIXElu-Cr5-LCS9 & 17.71 & $3.48 \mathrm{E}+04$ & $2.65 \mathrm{E}+00$ \\
\hline BNF-B310-TcIXElu-Cr5-LCS10 & 19.56 & $1.55 \mathrm{E}+04$ & $1.18 \mathrm{E}+00$ \\
\hline BNF-B310-TcIXElu-Cr5-LCS11 & 21.42 & $8.54 \mathrm{E}+03$ & $6.50 \mathrm{E}-01$ \\
\hline BNF-B310-TcIXElu-Cr5-LCS12 & 23.28 & $5.69 \mathrm{E}+03$ & $4.34 \mathrm{E}-01$ \\
\hline BNF-B310-TcIXElu-Cr5-LCS13 & 25.13 & $4.32 \mathrm{E}+03$ & $3.29 \mathrm{E}-01$ \\
\hline BNF-B310-TcIXElu-Cr5-LCS14 & 26.99 & $2.43 \mathrm{E}+03$ & $1.85 \mathrm{E}-01$ \\
\hline BNF-B310-TcIXElu-Cr5-LCS15 & 28.84 & $1.58 \mathrm{E}+03$ & $1.20 \mathrm{E}-01$ \\
\hline BNF-B310-TcIXElu-Cr5-LCS16 & 30.70 & $1.04 \mathrm{E}+03$ & $7.89 \mathrm{E}-02$ \\
\hline BNF-B310-TcIXElu-Cr5-LCS17 & 32.56 & $8.15 \mathrm{E}+02$ & $6.20 \mathrm{E}-02$ \\
\hline BNF-B310-TcIXElu-Cr5-LCS18 & 34.41 & $1.06 \mathrm{E}+03$ & $8.10 \mathrm{E}-02$ \\
\hline
\end{tabular}


Table 13. Characterization Data for Envelope B Decontaminated Product

\begin{tabular}{|c|c|c|c|c|c|c|c|}
\hline Sample ID & & AZ-102-Prod-1 & & AZ-102-Prod-2 & & avg. duplicate & $\%$ RSD \\
\hline Cs-137 ( $\mu \mathrm{Ci} / \mathrm{mL})$ & & $6.64 \mathrm{E}-01$ & & $6.31 \mathrm{E}-01$ & & $6.5 \mathrm{E}-01$ & 2.2 \\
\hline Co-60 $(\mu \mathrm{Ci} / \mathrm{mL})$ & $<$ & $2.40 \mathrm{E}-03$ & $<$ & $7.15 \mathrm{E}-04$ & $<$ & $1.6 \mathrm{E}-03$ & --- \\
\hline Eu-154 ( $\mu \mathrm{Ci} / \mathrm{mL})$ & $<$ & $6.73 \mathrm{E}-03$ & $<$ & $6.86 \mathrm{E}-03$ & $<$ & $6.8 \mathrm{E}-03$ & --- \\
\hline Eu-155 $(\mu \mathrm{Ci} / \mathrm{mL})$ & $<$ & $9.13 \mathrm{E}-03$ & $<$ & $8.90 \mathrm{E}-03$ & $<$ & $9.0 \mathrm{E}-03$ & --- \\
\hline Tc-99 (mg/L) & & $5.85 \mathrm{E}-03$ & & 9.34E-03* & & $7.6 \mathrm{E}-03$ & 23.0 \\
\hline $\mathrm{Pu}-238(\mu \mathrm{Ci} / \mathrm{mL})$ & & $2.28 \mathrm{E}-4$ & & $2.09 \mathrm{E}-4$ & & $2.21 \mathrm{E}-4$ & 5.4 \\
\hline $\mathrm{Pu}-239 / 240(\mu \mathrm{Ci} / \mathrm{mL})$ & & $4.55 \mathrm{E}-4$ & & $4.91 \mathrm{E}-4$ & & 4.73E-04 & 3.8 \\
\hline mass 230 & $<$ & $9.51 \mathrm{E}-02$ & $<$ & $9.51 \mathrm{E}-02$ & $<$ & $9.5 \mathrm{E}-02$ & --- \\
\hline 231 & $<$ & $9.51 \mathrm{E}-02$ & $<$ & $9.51 \mathrm{E}-02$ & $<$ & $9.5 \mathrm{E}-02$ & $\begin{array}{l}-- \\
-\end{array}$ \\
\hline 232 & & $5.79 \mathrm{E}+01$ & & $1.67 \mathrm{E}+01$ & & $3.7 \mathrm{E}+01$ & 54.9 \\
\hline 233 & $<$ & $9.51 \mathrm{E}-02$ & $<$ & $9.51 \mathrm{E}-02$ & $<$ & $9.5 \mathrm{E}-02$ & --- \\
\hline 234 & $<$ & $9.51 \mathrm{E}-02$ & $<$ & $9.51 \mathrm{E}-02$ & $<$ & $9.5 \mathrm{E}-02$ & --- \\
\hline 235 & & $2.56 \mathrm{E}+01$ & & $2.96 \mathrm{E}+01$ & & $2.8 \mathrm{E}+01$ & 8.6 \\
\hline 236 & $<$ & $9.51 \mathrm{E}-02$ & $<$ & $9.51 \mathrm{E}-02$ & $<$ & $9.5 \mathrm{E}-02$ & --- \\
\hline 237 & & $1.26 \mathrm{E}+02$ & & $1.46 \mathrm{E}+02$ & & $1.4 \mathrm{E}+02$ & 10 \\
\hline 238 & & $2.37 \mathrm{E}+03$ & & $2.31 \mathrm{E}+03$ & & $2.34 \mathrm{E}+03$ & 1.3 \\
\hline 239 & $<$ & $9.51 \mathrm{E}-02$ & $<$ & $5.44 \mathrm{E}-03$ & $<$ & $5.0 \mathrm{E}-02$ & $\begin{array}{l}-- \\
-\end{array}$ \\
\hline 240 & $<$ & $9.51 \mathrm{E}-02$ & $<$ & $5.44 \mathrm{E}-03$ & $<$ & $5.0 \mathrm{E}-02$ & $-\overline{--}$ \\
\hline 241 & $<$ & $9.51 \mathrm{E}-02$ & $<$ & $5.44 \mathrm{E}-03$ & $<$ & $5.0 \mathrm{E}-02$ & --- \\
\hline 242 & $<$ & $9.51 \mathrm{E}-02$ & $<$ & $5.44 \mathrm{E}-03$ & $<$ & $5.0 \mathrm{E}-02$ & --- \\
\hline 243 & $<$ & $9.51 \mathrm{E}-02$ & $<$ & $5.44 \mathrm{E}-03$ & $<$ & $5.0 \mathrm{E}-02$ & --- \\
\hline 244 & $<$ & $9.51 \mathrm{E}-02$ & $<$ & $5.44 \mathrm{E}-03$ & $<1$ & $5.0 \mathrm{E}-02$ & --- \\
\hline 245 & $<$ & $9.51 \mathrm{E}-02$ & $<$ & $5.44 \mathrm{E}-03$ & $<$ & $5.0 \mathrm{E}-02$ & --- \\
\hline 246 & $<$ & $9.51 \mathrm{E}-02$ & $<$ & $5.44 \mathrm{E}-03$ & $<$ & $5.0 \mathrm{E}-02$ & --- \\
\hline $\begin{array}{l}\text { U - }(\mathrm{mg} / \mathrm{L}) \text { by Chem } \\
\text { check }\end{array}$ & & $1.59 \mathrm{E}+00$ & & $1.63 \mathrm{E}+00$ & & $1.61 \mathrm{E}+00$ & 1.3 \\
\hline \multicolumn{8}{|l|}{\begin{tabular}{|l|}
$\mathbf{A A}$ \\
\end{tabular}} \\
\hline $\mathrm{K}(\mathrm{mg} / \mathrm{L})$ & & $2.68 \mathrm{E}+03$ & & $2.49 \mathrm{E}+03$ & & $2.58 \mathrm{E}+03$ & 3.6 \\
\hline $\mathrm{Na}(\mathrm{mg} / \mathrm{L})$ & & $5.16 \mathrm{E}+04$ & & $5.01 \mathrm{E}+04$ & & $5.09 \mathrm{E}+04$ & 1,6 \\
\hline As $(\mu \mathrm{g} / \mathrm{L})$ & & $3.18 \mathrm{E}+02$ & & $3.40 \mathrm{E}+02$ & & $3.29 \mathrm{E}+02$ & 3.3 \\
\hline $\operatorname{Se}(\mu \mathrm{g} / \mathrm{L})$ & & $4.08 \mathrm{E}+02$ & & $4.07 \mathrm{E}+02$ & & $4.07 \mathrm{E}+02$ & 1.2 \\
\hline $\mathrm{Hg}(\mu \mathrm{g} / \mathrm{L})$ & $<$ & $1.10 \mathrm{E}-01$ & $<$ & $1.12 \mathrm{E}-01$ & $<$ & $1.11 \mathrm{E}-01$ & $\overline{---}$ \\
\hline \multicolumn{8}{|l|}{ Carbon $(\mathrm{mg} / \mathrm{L})$} \\
\hline inorganic (TIC) & & $8.00 \mathrm{E}+03$ & & $9.23 \mathrm{E}+03$ & & $8.62 \mathrm{E}+03$ & 7.2 \\
\hline \begin{tabular}{|l} 
organic (TOC) \\
\end{tabular} & & $1.16 \mathrm{E}+04$ & & $5.05 \mathrm{E}+03$ & & $8.34 \mathrm{E}+03$ & 39.4 \\
\hline \multicolumn{8}{|l|}{ density $(\mathrm{g} / \mathrm{mL})$} \\
\hline wt.\% solids & & $7.72 \mathrm{E}-03$ & $<$ & $1.12 \mathrm{E}-03$ & $<$ & $4.42 \mathrm{E}-03$ & --- \\
\hline \multicolumn{8}{|l|}{ IC (mg/L) } \\
\hline $\mathrm{NO}_{3}^{-}$ & & $1.34 \mathrm{E}+04$ & & $1.33 \mathrm{E}+04$ & & $1.33 \mathrm{E}+04$ & 0.8 \\
\hline $\mathrm{NO}_{2}^{-}$ & & $2.62 \mathrm{E}+04$ & & $2.61 \mathrm{E}+04$ & & $2.61 \mathrm{E}+04$ & 0.4 \\
\hline PO4 & & $2.43 \mathrm{E}+02$ & & $2.47 \mathrm{E}+02$ & & $2.45 \mathrm{E}+02$ & 0.8 \\
\hline $\mathrm{SO} 4$ & & $1.34 \mathrm{E}+04$ & & $1.32 \mathrm{E}+04$ & & $1.33 \mathrm{E}+04$ & 0.8 \\
\hline Oxalate & & $2.38 \mathrm{E}+03$ & & $2.42 \mathrm{E}+03$ & & $2.4 \mathrm{E}+03$ & 0.8 \\
\hline Formate & $<$ & $1.10 \mathrm{E}+02$ & $<$ & $1.12 \mathrm{E}+02$ & $<$ & $1.1 \mathrm{E}+02$ & --- \\
\hline Cl- (by IC) & & $6.62 \mathrm{E}+01$ & & $6.75 \mathrm{E}+01$ & & $6.7 \mathrm{E}+01$ & 1.2 \\
\hline F- ( by IC) & & $8.60 \mathrm{E}+02$ & & $8.77 \mathrm{E}+02$ & & $8.69 \mathrm{E}+02$ & 1.0 \\
\hline Cl- (by ISE) & & $1.54 \mathrm{E}+02$ & & $2.10 \mathrm{E}+02$ & & $1.82 \mathrm{E}+02$ & 15.4 \\
\hline F- (by ISE) & & $8.60 \mathrm{E}+02$ & & $8.66 \mathrm{E}+02$ & & $8.63 \mathrm{E}+02$ & 0.3 \\
\hline
\end{tabular}


WSRC-TR-2000-00419

SRT-RPP-2000-00036 Revision 0

Table 13. Cont.

\begin{tabular}{|c|c|c|c|c|c|c|c|}
\hline ICP-ES (mg/L) & & AZ-102-Prod-1 & & AZ-102-Prod-2 & & avg. duplicate & $\%$ RSD \\
\hline $\mathrm{Al}$ & & $4.08 \mathrm{E}+02$ & & $3.96 \mathrm{E}+02$ & & $4.02 \mathrm{E}+02$ & 1.5 \\
\hline $\mathrm{B}$ & & $1.15 \mathrm{E}+00$ & & $1.12 \mathrm{E}+00$ & & $1.14 \mathrm{E}+00$ & 0.4 \\
\hline $\mathrm{Ba}$ & & $1.35 \mathrm{E}+00$ & & $1.34 \mathrm{E}+00$ & & $1.34 \mathrm{E}+00$ & 0 \\
\hline$\overline{\mathrm{Ca}}$ & & $6.84 \mathrm{E}-01$ & & $4.50 \mathrm{E}-01$ & & $5.67 \mathrm{E}-01$ & 20.6 \\
\hline $\mathrm{Cd}$ & $<$ & $6.62 \mathrm{E}-02$ & $<$ & $6.75 \mathrm{E}-02$ & $<$ & $6.68 \mathrm{E}-02$ & --- \\
\hline Co & & $1.21 \mathrm{E}-01$ & & $1.57 \mathrm{E}-01$ & & $1.39 \mathrm{E}-01$ & 13 \\
\hline $\mathrm{Cr}$ & & $5.35 \mathrm{E}+02$ & & $5.30 \mathrm{E}+02$ & & $5.33 \mathrm{E}+02$ & 0.6 \\
\hline $\mathrm{Cu}$ & $<$ & $6.62 \mathrm{E}-02$ & $<$ & $6.75 \mathrm{E}-02$ & $<$ & $6.68 \mathrm{E}-02$ & --- \\
\hline $\mathrm{Fe}$ & $<$ & $6.62 \mathrm{E}-02$ & $<$ & $6.75 \mathrm{E}-02$ & $<$ & $6.68 \mathrm{E}-02$ & --- \\
\hline $\mathrm{La}$ & $<$ & $2.43 \mathrm{E}-01$ & $<$ & $2.47 \mathrm{E}-01$ & $<$ & $2.45 \mathrm{E}-01$ & --- \\
\hline $\mathrm{Li}$ & $<$ & $4.41 \mathrm{E}-02$ & $<$ & 4.50E-02 & $<$ & $4.46 \mathrm{E}-02$ & --- \\
\hline $\mathrm{Mg}$ & $<$ & $2.21 \mathrm{E}-02$ & $<$ & $2.25 \mathrm{E}-02$ & $<$ & $2.23 \mathrm{E}-02$ & --- \\
\hline $\mathrm{Mn}$ & $<$ & $2.21 \mathrm{E}-02$ & $<$ & $2.25 \mathrm{E}-02$ & $<$ & $2.23 \mathrm{E}-02$ & --- \\
\hline Mo & & $4.31 \mathrm{E}+01$ & & $4.32 \mathrm{E}+01$ & & $4.32 \mathrm{E}+01$ & 0.2 \\
\hline $\mathrm{Na}$ & & $4.20 \mathrm{E}+04$ & & $4.05 \mathrm{E}+04$ & & $4.12 \mathrm{E}+04$ & 1.9 \\
\hline $\mathrm{Ni}$ & $<$ & $1.54 \mathrm{E}-01$ & $<$ & $1.57 \mathrm{E}-01$ & $<$ & $1.56 \mathrm{E}-01$ & --- \\
\hline $\mathrm{P}$ & & $1.38 \mathrm{E}+02$ & & $1.41 \mathrm{E}+02$ & & $1.39 \mathrm{E}+02$ & 1.4 \\
\hline $\mathrm{Pb}$ & & 9.93E-01 & & $1.35 \mathrm{E}+00$ & & $1.17 \mathrm{E}+00$ & 15.4 \\
\hline $\mathrm{Si}$ & & $8.69 \mathrm{E}+01$ & & $1.12 \mathrm{E}+02$ & & $9.95 \mathrm{E}+01$ & 12.6 \\
\hline $\mathrm{Sn}$ & & $6.86 \mathrm{E}+00$ & & $8.12 \mathrm{E}+00$ & & $7.49 \mathrm{E}+00$ & 8.4 \\
\hline $\mathrm{Sr}$ & $<$ & $2.21 \mathrm{E}-02$ & $<$ & $2.25 \mathrm{E}-02$ & $<$ & $2.23 \mathrm{E}-02$ & --- \\
\hline $\mathrm{Ti}$ & $<$ & $4.41 \mathrm{E}-02$ & $<$ & $4.50 \mathrm{E}-02$ & $<$ & $4.46 \mathrm{E}-02$ & --- \\
\hline $\mathrm{V}$ & & $3.53 \mathrm{E}-01$ & & $3.71 \mathrm{E}-01$ & & $3.62 \mathrm{E}-01$ & 2.5 \\
\hline $\mathrm{Zn}$ & & $4.63 \mathrm{E}-01$ & & $4.05 \mathrm{E}-01$ & & $4.34 \mathrm{E}-01$ & 6.7 \\
\hline Dilution factors & & 11.03 & & 11.25 & & $\mathrm{n} / \mathrm{a}$ & \\
\hline
\end{tabular}

* The [Tc-99] reported for sample "AZ-102-Prod-2" is 60\% higher than was reported for sample "AZ-102Prod-1". In addition, the guard column effluent samples collected during column loading (Table 11) indicated that the [Tc-99] should be $\sim 5 \mathrm{E}-02 \mathrm{mg} / \mathrm{L}$. These observations indicate that the [Tc-99] reported for sample "AZ-102-Prod-2" is incorrect. 
Table 14. Characterization Data for Lead Column Cesium Eluate Product (1:50 Water Dilution)

\begin{tabular}{|c|c|c|}
\hline ICP-MS (mg/L) & & \\
\hline Mass & $3-138651$ & 3-140095 \\
\hline 85 & --- & 0.451 \\
\hline 87 & --- & 1.003 \\
\hline 88 & --- & 0.065 \\
\hline 90 & --- & 0.036 \\
\hline 94 & --- & 0.008 \\
\hline 96 & --- & 0.012 \\
\hline $99(\mathrm{Tc})$ & --- & 0.010 \\
\hline 101 & --- & 0.007 \\
\hline 102 & --- & 0.004 \\
\hline 103 & --- & 0.005 \\
\hline 106 & --- & 0.011 \\
\hline 107 & --- & 0.120 \\
\hline 109 & --- & 0.093 \\
\hline 110 & --- & 0.096 \\
\hline 111 & --- & 0.103 \\
\hline 112 & --- & 0.201 \\
\hline 114 & --- & 0.247 \\
\hline 115 & --- & 0.000 \\
\hline 116 & --- & 0.059 \\
\hline 119 & --- & 0.054 \\
\hline 120 & --- & 0.016 \\
\hline $133(\mathrm{Cs})$ & 101.650 & 81.118 \\
\hline 134 & --- & 0.086 \\
\hline $135(\mathrm{Cs})$ & 33.600 & 25.153 \\
\hline 136 & --- & 0.284 \\
\hline 137 (Cs) & 73.000 & 57.253 \\
\hline 138 & --- & 2.382 \\
\hline 139 & --- & 0.047 \\
\hline 140 & --- & 0.011 \\
\hline 142 & --- & 0.019 \\
\hline 143 & --- & 0.009 \\
\hline 144 & --- & 0.019 \\
\hline 145 & --- & 0.007 \\
\hline 146 & --- & 0.012 \\
\hline 148 & --- & 0.007 \\
\hline 154 & --- & 0.007 \\
\hline 155 & --- & 0.006 \\
\hline 206 & --- & 0.050 \\
\hline 207 & --- & 0.047 \\
\hline 208 & --- & 0.105 \\
\hline 238 & 11.175 & 8.433 \\
\hline 239 & 0.51 & 0.482 \\
\hline
\end{tabular}


Table 14. (Cont.)

\begin{tabular}{|c|c|c|c|c|c|c|}
\hline ADS\# & & 3-138649 & & 3-140094 & & Average \\
\hline \multicolumn{7}{|l|}{ Carbon (mg/L) } \\
\hline Inorganic (TIC) & & $5.25 \mathrm{E}+01$ & $<$ & $5.00 \mathrm{E}+01$ & & \\
\hline Organic (TOC) & & $2.42 \mathrm{E}+02$ & & $1.94 \mathrm{E}+02$ & & \\
\hline ADS\# & & 3-138649 & & 3-140093 & & \\
\hline \multicolumn{7}{|l|}{ IC (mg/L) } \\
\hline $\mathrm{NO}_{3}{ }^{-}$ & & $2.26 \mathrm{E}+04$ & & $2.00 \mathrm{E}+04$ & & $2.13 \mathrm{E}+04$ \\
\hline $\mathrm{NO}_{2}^{-}$ & $<$ & $5.00 \mathrm{E}+02$ & $<$ & $5.00 \mathrm{E}+02$ & $<$ & $5.00 \mathrm{E}+02$ \\
\hline$\overline{\mathrm{PO} 4}$ & $<$ & $5.00 \mathrm{E}+02$ & $<$ & $5.00 \mathrm{E}+02$ & $<$ & $5.00 \mathrm{E}+02$ \\
\hline $\mathrm{SO} 4$ & $<$ & $2.50 \mathrm{E}+02$ & $<$ & $2.50 \mathrm{E}+02$ & $<$ & $2.50 \mathrm{E}+02$ \\
\hline Oxalate & $<$ & $5.00 \mathrm{E}+02$ & $<$ & $5.00 \mathrm{E}+02$ & $<$ & $5.00 \mathrm{E}+02$ \\
\hline Formate & $<$ & $5.00 \mathrm{E}+02$ & $<$ & $5.00 \mathrm{E}+02$ & $<$ & $5.00 \mathrm{E}+02$ \\
\hline $\mathrm{Cl}-$ by IC & $<$ & $1.00 \mathrm{E}+02$ & $<$ & $1.00 \mathrm{E}+02$ & $<$ & $1.00 \mathrm{E}+02$ \\
\hline F- by IC & $<$ & $1.00 \mathrm{E}+02$ & $<$ & $1.00 \mathrm{E}+02$ & $<$ & $1.00 \mathrm{E}+02$ \\
\hline $\mathrm{Cl}-$ (by ISE) & & $8.05 \mathrm{E}+03$ & & $1.80 \mathrm{E}+03$ & & $4.93 \mathrm{E}+03$ \\
\hline F- (by ISE) & $<$ & $5.00 \mathrm{E}+01$ & $<$ & $5.0 \mathrm{E}+01$ & $<$ & $5.00 \mathrm{E}+02$ \\
\hline \multicolumn{7}{|l|}{ AA (mg/L) } \\
\hline $\mathrm{Na}$ & & --- & & 722.15 & & \\
\hline $\mathrm{K}$ & & --- & & 61.08 & & \\
\hline $\mathrm{Hg}$ & & --- & & 0.39 & & \\
\hline Cs & & $\begin{array}{ll}-- \\
\end{array}$ & & 164.25 & & \\
\hline As & & --- & $<$ & 4.31 & & \\
\hline ADS\# & & $3-138650$ & & 3-140094 & & \\
\hline Cs-137 $(\mu \mathrm{Ci} / \mathrm{mL})$ & & $6.80 \mathrm{E}+03$ & & $5.17 \mathrm{E}+03$ & & $5.99 \mathrm{E}+03$ \\
\hline $\mathrm{Pu}-238(\mu \mathrm{Ci} / \mathrm{mL})$ & & $1.45 \mathrm{E}-02$ & & $3.94 \mathrm{E}-03$ & & $9.23 \mathrm{E}-03 *$ \\
\hline $\mathrm{Pu}-239(\mu \mathrm{Ci} / \mathrm{mL})$ & & $3.6 \mathrm{E}-02$ & & $2.32 \mathrm{E}-02$ & & $2.96 \mathrm{E}-02$ \\
\hline Sr-90 $(\mu \mathrm{Ci} / \mathrm{mL})$ & & $3.58 \mathrm{E} 00$ & & $2.86 \mathrm{E} 00$ & & $3.22 \mathrm{E} 00$ \\
\hline Am-241 $(\mu \mathrm{Ci} / \mathrm{mL})$ & & $7.16 \mathrm{E}-03$ & & $2.70 \mathrm{E}-03$ & & $4.93 \mathrm{E}-03 *$ \\
\hline $\mathrm{Cm}-244(\mu \mathrm{Ci} / \mathrm{mL})$ & & $5.63 \mathrm{E}-02$ & & $2.64 \mathrm{E}-02$ & & $5.45 \mathrm{E}-02 *$ \\
\hline
\end{tabular}

Comments: These samples were prepared by collecting two samples of cesium eluate from the composite bottle and diluting each sample 1:50 with water. Each of the diluted samples were then split into three portions and submitted for analysis. Samples 300138649-50 were all portions of the same diluted eluate sample. Likewise, samples 300140093-95 were all portions of a second diluted eluate sample.

*All of the analysis results for sample set 300138649-50 appear to be higher than the results for sample set 300140093-95. This indicates that a dilution error occurred during preparation of the samples for analysis. Analysis results for duplicate samples vaaried considerably for the samples marked with an asterisk. 
Table 15. Characterization Data for Lead Column Cesium Eluate Product (1:30 0.5 M $\mathrm{HNO}_{3}$ Dilution)

\begin{tabular}{|c|c|c|c|c|c|c|c|}
\hline ICP-ES (mg/L) & & 300142044 & & 300142043 & & Average & $\%$ RSD \\
\hline$\overline{\mathrm{Al}}$ & & $1.89 \mathrm{E}+00$ & & $2.70 \mathrm{E}+00$ & & $2.30 \mathrm{E}+00$ & 17.8 \\
\hline B & & $7.20 \mathrm{E}-01$ & & $7.80 \mathrm{E}-01$ & & $7.50 \mathrm{E}-01$ & 4 \\
\hline $\mathrm{Ba}$ & & $8.10 \mathrm{E}-01$ & & $9.00 \mathrm{E}-01$ & & $8.55 \mathrm{E}-01$ & 5.3 \\
\hline $\mathrm{Ca}$ & & $3.12 \mathrm{E}+00$ & & $5.40 \mathrm{E}+00$ & & $4.26 \mathrm{E}+00$ & 26.8 \\
\hline $\mathrm{Cd}$ & & 5.70E-01 & & $5.70 \mathrm{E}-01$ & & $5.70 \mathrm{E}-01$ & 0 \\
\hline $\mathrm{Co}$ & $<$ & $3.00 \mathrm{E}-01$ & $<$ & $3.00 \mathrm{E}-01$ & $<$ & $3.00 \mathrm{E}-01$ & --- \\
\hline $\mathrm{Cr}$ & & $2.41 \mathrm{E}+01$ & & $2.42 \mathrm{E}+01$ & & $2.41 \mathrm{E}+01$ & 0 \\
\hline $\mathrm{Cu}$ & $<$ & $1.80 \mathrm{E}-01$ & $<$ & $1.80 \mathrm{E}-01$ & $<$ & $1.80 \mathrm{E}-01$ & --- \\
\hline $\mathrm{Fe}$ & & $1.05 \mathrm{E}+00$ & & $1.32 \mathrm{E}+00$ & & $1.19 \mathrm{E}+00$ & 11.8 \\
\hline $\mathrm{La}$ & $<$ & $6.60 \mathrm{E}-01$ & $<$ & $6.60 \mathrm{E}-01$ & $<$ & $6.60 \mathrm{E}-01$ & --- \\
\hline $\mathrm{Li}$ & $<$ & $1.20 \mathrm{E}-01$ & $<$ & $1.20 \mathrm{E}-01$ & $<$ & $1.20 \mathrm{E}-01$ & --- \\
\hline $\mathrm{Mg}$ & & $3.30 \mathrm{E}-01$ & & $3.60 \mathrm{E}-01$ & & $3.45 \mathrm{E}-01$ & 4.4 \\
\hline $\mathrm{Mn}$ & $<$ & $6.00 \mathrm{E}-02$ & $<$ & $6.00 \mathrm{E}-02$ & $<$ & $6.00 \mathrm{E}-02$ & --- \\
\hline Mo & $<$ & $3.60 \mathrm{E}-01$ & $<$ & $3.60 \mathrm{E}-01$ & $<$ & $3.60 \mathrm{E}-01$ & --- \\
\hline $\mathrm{Na}$ & & $9.26 \mathrm{E}+02$ & & $9.29 \mathrm{E}+02$ & & $9.27 \mathrm{E}+02$ & 0.2 \\
\hline $\mathrm{Ni}$ & $<$ & $4.20 \mathrm{E}-01$ & & $4.80 \mathrm{E}-01$ & & $4.50 \mathrm{E}-01$ & --- \\
\hline $\mathrm{P}$ & $<$ & $1.56 \mathrm{E}+00$ & & $2.10 \mathrm{E}+00$ & & $1.83 \mathrm{E}+00$ & --- \\
\hline $\mathrm{Pb}$ & $<$ & $1.68 \mathrm{E}+00$ & $<$ & $1.68 \mathrm{E}+00$ & $<$ & $1.68 \mathrm{E}+00$ & --- \\
\hline $\mathrm{Si}$ & $<$ & $9.60 \mathrm{E}-01$ & $<$ & $9.60 \mathrm{E}-01$ & $<$ & $9.60 \mathrm{E}-01$ & --- \\
\hline $\mathrm{Sn}$ & $<$ & $9.00 \mathrm{E}-01$ & $<$ & $9.00 \mathrm{E}-01$ & $<$ & $9.00 \mathrm{E}-01$ & --- \\
\hline $\mathrm{Sr}$ & $<$ & $6.00 \mathrm{E}-02$ & & $9.00 \mathrm{E}-02$ & & $7.50 \mathrm{E}-02$ & --- \\
\hline $\mathrm{Ti}$ & $<$ & $1.20 \mathrm{E}-01$ & $<$ & $1.20 \mathrm{E}-01$ & $<$ & $1.20 \mathrm{E}-01$ & --- \\
\hline $\mathrm{V}$ & $<$ & $1.80 \mathrm{E}-01$ & $<$ & $1.80 \mathrm{E}-01$ & $<$ & $1.80 \mathrm{E}-01$ & --- \\
\hline $\mathrm{Zn}$ & $<$ & $1.80 \mathrm{E}-01$ & & $3.60 \mathrm{E}-01$ & & $2.70 \mathrm{E}-01$ & --- \\
\hline $\mathrm{Zr}$ & $<$ & $2.40 \mathrm{E}-01$ & $<$ & $2.40 \mathrm{E}-01$ & $<$ & $2.40 \mathrm{E}-01$ & --- \\
\hline ADS\# & & 300142044 & & 300142043 & & Average & \\
\hline Cs-137 $(\mu \mathrm{Ci} / \mathrm{mL})$ & & $6.20 \mathrm{E}+03$ & & $5.94 \mathrm{E}+03$ & & $6.07 \mathrm{E}+03$ & 2.1 \\
\hline $\mathrm{Pu}-238(\mu \mathrm{Ci} / \mathrm{mL})$ & & $5.58 \mathrm{E}-02$ & & $9.59 \mathrm{E}-02$ & & $7.59 \mathrm{E}-02$ & 17.9 \\
\hline $\mathrm{Pu}-239 / 240(\mu \mathrm{Ci} / \mathrm{mL})$ & & $2.46 \mathrm{E}-01$ & & $2.69 \mathrm{E}-01$ & & $2.57 \mathrm{E}-01$ & 4.3 \\
\hline Sr-90 $(\mu \mathrm{Ci} / \mathrm{mL})$ & & $3.59 \mathrm{E}+00$ & & $2.72 \mathrm{E}+00$ & & $3.16 \mathrm{E}+00$ & 13.6 \\
\hline Tc-99 $(\mu \mathrm{Ci} / \mathrm{mL})$ & & $6.74 \mathrm{E}-03$ & & $<3.97 \mathrm{E}-03$ & & $<5.36 \mathrm{E}-03$ & --- \\
\hline Am-241 $(\mu \mathrm{Ci} / \mathrm{mL})$ & & $3.03 \mathrm{E}-03$ & & $8.27 \mathrm{E}-03$ & & $5.65 \mathrm{E}-03$ & 46.4 \\
\hline $\mathrm{Cm}-244(\mu \mathrm{Ci} / \mathrm{mL})$ & & $2.62 \mathrm{E}-02$ & & $2.68 \mathrm{E}-02$ & & $2.65 \mathrm{E}-02$ & 1.1 \\
\hline
\end{tabular}

Comment: Analytical results are generally within acceptable ranges for \% RSD (i.e., \pm 20 ), with the exception of $\mathrm{Ca}$ and $\mathrm{Am}-241$. Ca may have precipitated during waste processing, leading to inconsistent analytical results. Reported Am-241 concentrations are near the detection limit and would be expected to exhibit larger relative standard deviation. 
Table 16. Characterization Data for Technetium Eluate Product

\begin{tabular}{|c|c|c|c|c|c|c|c|}
\hline Sample ID & & $\begin{array}{c}\text { BNF-AZ102 } \\
\text { Tc-eluate-1-1 }\end{array}$ & & \begin{tabular}{|c|} 
BNF-AZ102 \\
Tc-eluate-1-1D \\
\end{tabular} & & $\begin{array}{c}\text { avg. duplicate } \\
\text { samples }\end{array}$ & $\%$ RSD \\
\hline Cs-137 $(\mu \mathrm{Ci} / \mathrm{mL})$ & & $2.81 \mathrm{E}-01$ & & $2.93 \mathrm{E}-01$ & & $2.87 \mathrm{E}-01$ & 2.1 \\
\hline Co-60 & $<$ & $1.88 \mathrm{E}-03$ & $<$ & $2.37 \mathrm{E}-03$ & $<$ & $2.12 \mathrm{E}-03$ & \\
\hline Eu-154 & $<$ & $4.47 \mathrm{E}-03$ & $<$ & $4.86 \mathrm{E}-03$ & $<$ & $4.66 \mathrm{E}-03$ & \\
\hline Eu-155 & $<$ & $6.45 \mathrm{E}-03$ & $<$ & $6.19 \mathrm{E}-03$ & $\overline{<}$ & $6.32 \mathrm{E}-03$ & \\
\hline Tc-99 ( $\mu \mathrm{g} / \mathrm{L})$ & & $3.92 \mathrm{E}+04$ & & $3.97 \mathrm{E}+04$ & & $3.94 \mathrm{E}+04$ & 0.5 \\
\hline mass $230(\mu \mathrm{g} / \mathrm{L})$ & $<$ & $9.34 \mathrm{E}-02$ & $<$ & $9.34 \mathrm{E}-02$ & $<$ & $9.34 \mathrm{E}-02$ & \\
\hline 231 & $<$ & $9.34 \mathrm{E}-02$ & $<$ & $9.34 \mathrm{E}-02$ & $<$ & $9.34 \mathrm{E}-02$ & \\
\hline 232 & $<$ & $9.34 \mathrm{E}-02$ & $<$ & $9.34 \mathrm{E}-02$ & & $9.34 \mathrm{E}-02$ & 0 \\
\hline 233 & $<$ & $9.34 \mathrm{E}-02$ & $<$ & $9.34 \mathrm{E}-02$ & $<$ & $9.34 \mathrm{E}-02$ & \\
\hline 234 & $<$ & $9.34 \mathrm{E}-02$ & $<$ & $9.34 \mathrm{E}-02$ & $<$ & $9.34 \mathrm{E}-02$ & \\
\hline 235 & $<$ & $9.34 \mathrm{E}-02$ & $<$ & $9.34 \mathrm{E}-02$ & $<$ & $9.34 \mathrm{E}-02$ & 0 \\
\hline 236 & $<$ & $9.34 \mathrm{E}-02$ & $<$ & $9.34 \mathrm{E}-02$ & $\overline{<}$ & $9.34 \mathrm{E}-02$ & \\
\hline 237 & $<$ & $9.34 \mathrm{E}-02$ & $<$ & $9.34 \mathrm{E}-02$ & $<$ & $9.34 \mathrm{E}-02$ & \\
\hline 238 & & $9.73 \mathrm{E}+01$ & 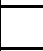 & $7.41 \mathrm{E}+01$ & & $8.57 \mathrm{E}+01$ & 15.7 \\
\hline 239 & $<$ & $9.34 \mathrm{E}-02$ & $<$ & $9.38 \mathrm{E}-02$ & $<$ & $9.36 \mathrm{E}-02$ & \\
\hline 240 & $<$ & $9.34 \mathrm{E}-02$ & $<$ & $9.38 \mathrm{E}-02$ & $\overline{<}$ & $9.36 \mathrm{E}-02$ & \\
\hline 241 & $<$ & $9.34 \mathrm{E}-02$ & $<$ & $9.38 \mathrm{E}-02$ & $<$ & $9.36 \mathrm{E}-02$ & \\
\hline 242 & $<$ & $9.34 \mathrm{E}-02$ & $<$ & $9.38 \mathrm{E}-02$ & $<$ & $9.36 \mathrm{E}-02$ & \\
\hline 243 & $<$ & 9.34E-02 & $<$ & $9.38 \mathrm{E}-02$ & $<$ & $9.36 \mathrm{E}-02$ & \\
\hline 244 & $<$ & $9.34 \mathrm{E}-02$ & $<$ & $9.38 \mathrm{E}-02$ & $<$ & $9.36 \mathrm{E}-02$ & \\
\hline 245 & $<$ & $9.34 \mathrm{E}-02$ & $<$ & $9.38 \mathrm{E}-02$ & $<$ & $9.36 \mathrm{E}-02$ & \\
\hline 246 & $<$ & $9.34 \mathrm{E}-02$ & $<$ & $9.38 \mathrm{E}-02$ & $<$ & $9.36 \mathrm{E}-02$ & \\
\hline $\mathrm{Pu}-238(\mu \mathrm{Ci} / \mathrm{mL})$ & & $2.95 \mathrm{E}-04$ & & $5.95 \mathrm{E}-05$ & & $1.77 \mathrm{E}-04$ & 66.4 \\
\hline $\mathrm{Pu}-239 / 240(\mu \mathrm{Ci} / \mathrm{mL})$ & & $1.06 \mathrm{E}-02$ & & $1.90 \mathrm{E}-02$ & & $1.48 \mathrm{E}-02$ & 28.4 \\
\hline \multicolumn{8}{|l|}{\begin{tabular}{|l}
$\mathbf{A A}(\mathbf{m g} / \mathbf{L})$ \\
\end{tabular}} \\
\hline $\mathrm{K}$ & & $7.79 \mathrm{E}+01$ & & $7.98 \mathrm{E}+01$ & & $7.88 \mathrm{E}+01$ & 1.1 \\
\hline $\mathrm{Na}$ & & $2.11 \mathrm{E}+03$ & & $2.17 \mathrm{E}+03$ & & $2.14 \mathrm{E}+03$ & 1.4 \\
\hline As & & $8.51 \mathrm{E}-02$ & & $9.14 \mathrm{E}-02$ & & $8.82 \mathrm{E}-02$ & 3.5 \\
\hline $\mathrm{Se}$ & & $5.26 \mathrm{E}-02$ & & $6.36 \mathrm{E}-02$ & & $5.81 \mathrm{E}-02$ & 9.5 \\
\hline $\mathrm{Hg}$ & $<$ & $1.08 \mathrm{E}-04$ & $<$ & $1.09 \mathrm{E}-04$ & $<$ & $1.09 \mathrm{E}-04$ & \\
\hline U-(mg/L) by Chem & $<$ & $1.08 \mathrm{E}-01$ & $<$ & $1.09 \mathrm{E}-01$ & $<$ & $1.09 \mathrm{E}-01$ & \\
\hline \multicolumn{8}{|l|}{ Carbon (mg/L) } \\
\hline inorganic (TIC) & & $1.84 \mathrm{E}+02$ & & $1.85 \mathrm{E}+02$ & & $1.85 \mathrm{E}+02$ & 0.1 \\
\hline organic (TOC) & & $1.52 \mathrm{E}+02$ & & $1.52 \mathrm{E}+02$ & & $1.52 \mathrm{E}+02$ & 0 \\
\hline \multicolumn{8}{|l|}{ IC (mg/L) } \\
\hline $\mathrm{NO}_{3}{ }^{-}$ & & $4.23 \mathrm{E}+02$ & & $4.24 \mathrm{E}+02$ & & $4.24 \mathrm{E}+02$ & 0.1 \\
\hline $\mathrm{NO}_{2}^{-}$ & & $5.42 \mathrm{E}+02$ & & $5.44 \mathrm{E}+02$ & & $5.43 \mathrm{E}+02$ & 0.2 \\
\hline $\mathrm{PO}_{4}{ }^{3-}$ & $<$ & $1.08 \mathrm{E}+03$ & $<$ & $1.09 \mathrm{E}+02$ & $<$ & $5.96 \mathrm{E}+02$ & \\
\hline $\mathrm{SO}_{4}{ }^{2-}$ & & $3.14 \mathrm{E}+02$ & $<$ & $3.16 \mathrm{E}+02$ & $<$ & $3.15 \mathrm{E}+02$ & \\
\hline Oxalate & $<$ & $1.08 \mathrm{E}+03$ & $<$ & $1.09 \mathrm{E}+02$ & $<$ & $5.96 \mathrm{E}+02$ & \\
\hline Formate & $<$ & $2.81 \mathrm{E}+00$ & $<$ & $1.09 \mathrm{E}+02$ & $<$ & $5.58 \mathrm{E}+01$ & \\
\hline $\mathrm{Cl}^{-}$by $\mathrm{IC}$ & $<$ & $2.17 \mathrm{E}+01$ & $<$ & $2.18 \mathrm{E}+01$ & $<$ & $2.17 \mathrm{E}+01$ & \\
\hline $\mathrm{F}^{-}$by $\mathrm{IC}$ & $<$ & $1.08 \mathrm{E}+01$ & $<$ & $1.09 \mathrm{E}+01$ & $<$ & $1.09 \mathrm{E}+01$ & \\
\hline $\mathrm{Cl}^{-}$(by ISE) & & $1.08 \mathrm{E}+02$ & & $9.79 \mathrm{E}+01$ & & $1.03 \mathrm{E}+02$ & 4.9 \\
\hline $\mathrm{F}^{-}$(by ISE) & $<$ & $1.08 \mathrm{E}+01$ & $<$ & $1.09 \mathrm{E}+01$ & $<$ & $1.09 \mathrm{E}+01$ & \\
\hline
\end{tabular}


Table 16. Cont.

\begin{tabular}{|c|c|c|c|c|c|c|c|}
\hline Sample ID & & $\begin{array}{c}\text { BNF-AZ102 } \\
\text { Tc-eluate-1-1 }\end{array}$ & & $\begin{array}{c}\text { BNF-AZ102 } \\
\text { Tc-eluate-1-1D }\end{array}$ & & $\begin{array}{l}\text { avg. duplicate } \\
\text { samples }\end{array}$ & $\%$ RSD \\
\hline \multicolumn{8}{|l|}{\begin{tabular}{|l} 
ICP-ES (mg/L) \\
\end{tabular}} \\
\hline$\overline{A l}$ & & $4.22 \mathrm{E}+01$ & & $4.24 \mathrm{E}+01$ & & $4.23 \mathrm{E}+01$ & 0.2 \\
\hline $\mathrm{B}$ & & $8.73 \mathrm{E}+00$ & & $8.67 \mathrm{E}+00$ & & $8.70 \mathrm{E}+00$ & 0.3 \\
\hline $\mathrm{Ba}$ & & $1.89 \mathrm{E}+00$ & & $1.94 \mathrm{E}+00$ & & $1.91 \mathrm{E}+00$ & 1.6 \\
\hline $\mathrm{Ca}$ & & $3.04 \mathrm{E}-01$ & & $7.18 \mathrm{E}-01$ & & $5.11 \mathrm{E}-01$ & 40.5 \\
\hline $\mathrm{Cd}$ & & $3.47 \mathrm{E}-01$ & & $4.46 \mathrm{E}-01$ & & $3.96 \mathrm{E}-01$ & 12.6 \\
\hline $\mathrm{Co}$ & & $9.11 \mathrm{E}-01$ & & $1.08 \mathrm{E}+00$ & & 9.94E-01 & 8.7 \\
\hline $\mathrm{Cr}$ & & $1.55 \mathrm{E}+01$ & & $1.55 \mathrm{E}+01$ & & $1.55 \mathrm{E}+01$ & 0 \\
\hline $\mathrm{Cu}$ & & $6.72 \mathrm{E}-01$ & & $7.18 \mathrm{E}-01$ & & $6.95 \mathrm{E}-01$ & 3.3 \\
\hline $\mathrm{Fe}$ & & $4.99 \mathrm{E}-01$ & & $5.66 \mathrm{E}-01$ & & 5.32E-01 & 6.4 \\
\hline $\mathrm{La}$ & & $1.60 \mathrm{E}+00$ & & $1.69 \mathrm{E}+00$ & & $1.65 \mathrm{E}+00$ & 3.0 \\
\hline $\mathrm{Li}$ & & $4.23 \mathrm{E}-01$ & & $4.46 \mathrm{E}-01$ & & $4.34 \mathrm{E}-01$ & 2.5 \\
\hline $\mathrm{Mg}$ & $<$ & $1.08 \mathrm{E}-01$ & $<$ & $1.09 \mathrm{E}-01$ & $<$ & $1.09 \mathrm{E}-01$ & --- \\
\hline $\mathrm{Mn}$ & & $1.41 \mathrm{E}-01$ & & $1.63 \mathrm{E}-01$ & & $1.52 \mathrm{E}-01$ & 7.2 \\
\hline Mo & & $1.71 \mathrm{E}+00$ & & $1.59 \mathrm{E}+00$ & & $1.65 \mathrm{E}+00$ & 3.6 \\
\hline $\mathrm{Na}$ & & $2.07 \mathrm{E}+03$ & & $2.06 \mathrm{E}+03$ & & $2.06 \mathrm{E}+03$ & 0.2 \\
\hline $\mathrm{Ni}$ & & $1.15 \mathrm{E}+00$ & & $9.47 \mathrm{E}-01$ & & $1.05 \mathrm{E}+00$ & 9.8 \\
\hline $\mathrm{P}$ & & $7.72 \mathrm{E}+00$ & & $6.95 \mathrm{E}+00$ & & $7.34 \mathrm{E}+00$ & 5.3 \\
\hline $\mathrm{Pb}$ & & $4.51 \mathrm{E}+00$ & & $4.77 \mathrm{E}+00$ & & $4.64 \mathrm{E}+00$ & 2.8 \\
\hline $\mathrm{Si}$ & & $6.80 \mathrm{E}+00$ & & $6.19 \mathrm{E}+00$ & & $6.49 \mathrm{E}+00$ & 4.6 \\
\hline $\mathrm{Sn}$ & $<$ & $2.48 \mathrm{E}+00$ & $<$ & $1.63 \mathrm{E}+00$ & $<$ & $2.06 \mathrm{E}+00$ & --- \\
\hline $\mathrm{Sr}$ & & $1.95 \mathrm{E}-01$ & & $1.96 \mathrm{E}-01$ & & $1.95 \mathrm{E}-01$ & 0.2 \\
\hline $\mathrm{Ti}$ & & $9.11 \mathrm{E}-01$ & & $9.36 \mathrm{E}-01$ & & $9.23 \mathrm{E}-01$ & 1.3 \\
\hline $\mathrm{V}$ & & $1.04 \mathrm{E}+00$ & & $1.10 \mathrm{E}+00$ & & $1.07 \mathrm{E}+00$ & 2.8 \\
\hline $\mathrm{Zn}$ & $<$ & $3.25 \mathrm{E}-01$ & $<$ & $3.26 \mathrm{E}-01$ & $<$ & $3.26 \mathrm{E}-01$ & --- \\
\hline Dilution factors & & 10.8 & & 10.9 & & & \\
\hline
\end{tabular}

Free $\mathrm{OH}^{-}$and Repeated IC Anion Analysis (freshly-prepared samples submitted without dilution to obtain better detection limits)

\begin{tabular}{|c|c|c|c|c|c|c|}
\hline \multicolumn{7}{|l|}{ IC (mg/L) } \\
\hline \multicolumn{2}{|l|}{ ADS \# } & 300148106 & & 300148109 & & Average \\
\hline $\mathrm{NO}_{3}^{-}$ & & 695 & & 696 & & 696 \\
\hline $\mathrm{NO}_{2}^{-}$ & & 578 & & 581 & & 580 \\
\hline $\mathrm{PO}_{4}^{3-}$ & $<$ & 100 & $<$ & 100 & $<$ & 100 \\
\hline $\mathrm{SO}_{4}{ }^{2-}$ & & 597 & & 596 & & 597 \\
\hline Oxalate & & 212 & & 216 & & 214 \\
\hline Formate & $<$ & 100 & $<$ & 100 & $<$ & 100 \\
\hline $\mathrm{Cl}^{-}$ & & 342 & & 346 & & 344 \\
\hline $\mathrm{F}^{-}$ & $<$ & 20 & $<$ & 20 & $<$ & 20 \\
\hline Dilution Factor & & 1.0 & & 1.0 & & $\mathrm{n} / \mathrm{a}$ \\
\hline ADS\# & & 300148848 & & 300148849 & & Average \\
\hline Free $\mathrm{OH}^{-}(\mathrm{M})$ & & 0.052 & & 0.051 & & 0.052 \\
\hline Dilution Factor & & 9.4 & & 10.3 & & \\
\hline
\end{tabular}




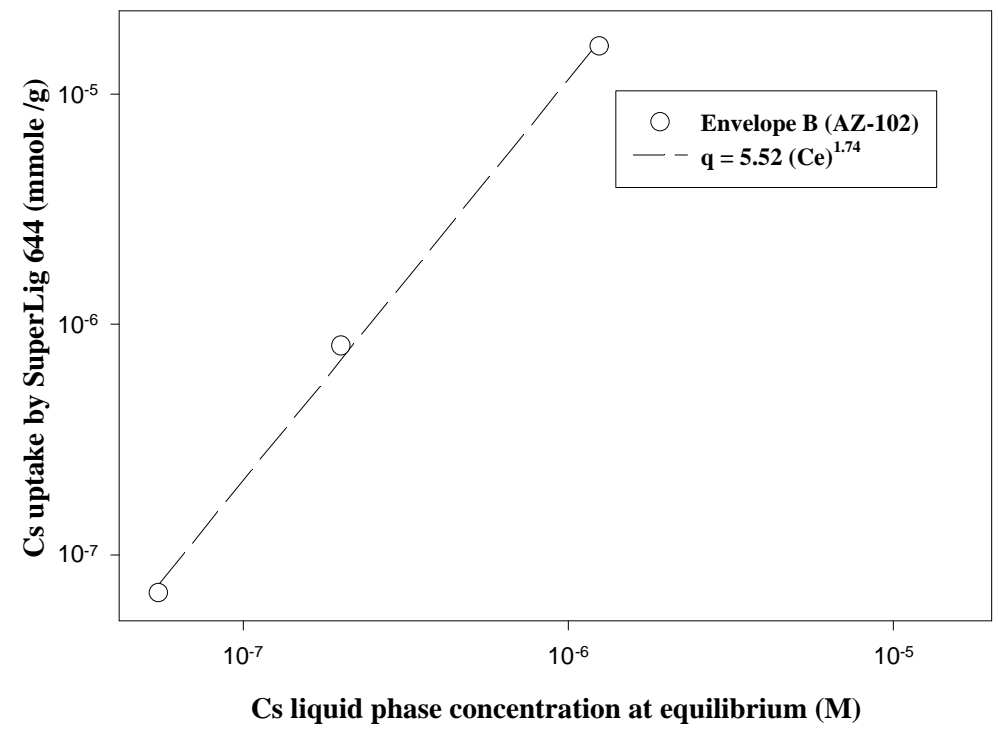

Figure 1 Equilibrium isotherm for cesium on SuperLig 644 resin

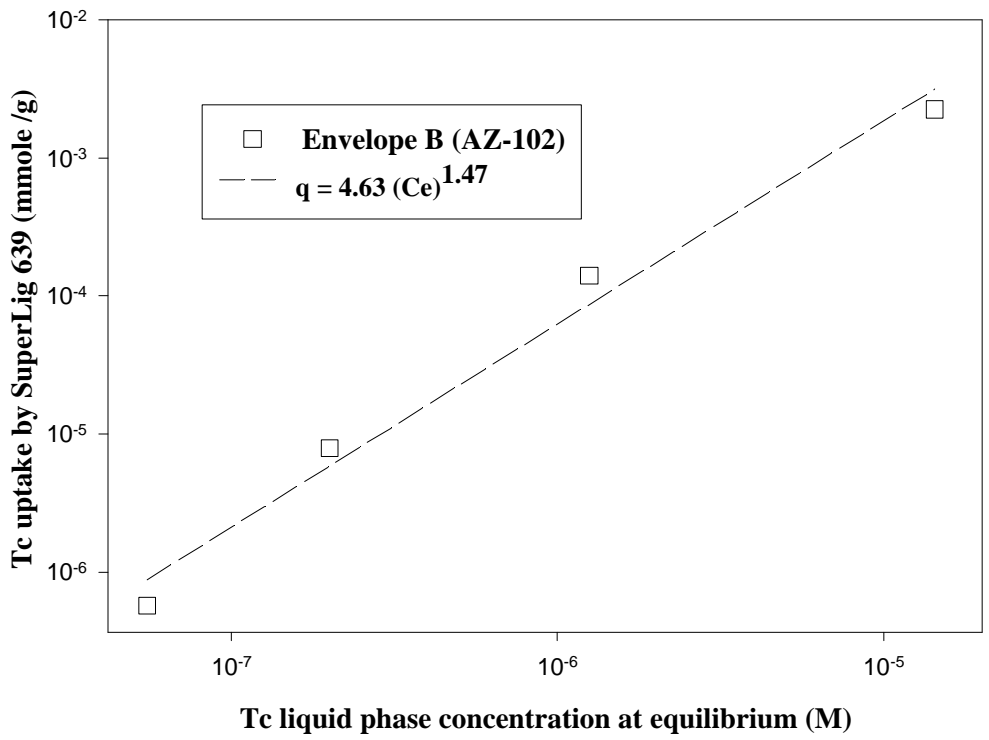

Figure 2 . Equilibrium isotherm for technetium on SuperLig 639 resin 


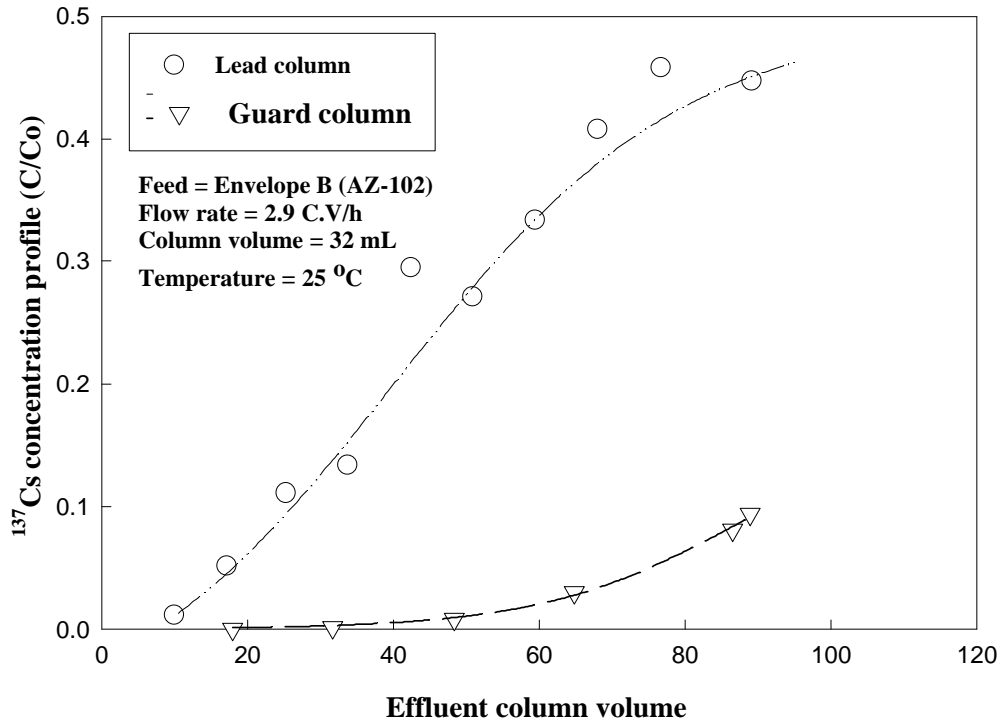

Figure 3. Breakthrough curve for Cs on SuperLig 644 resin

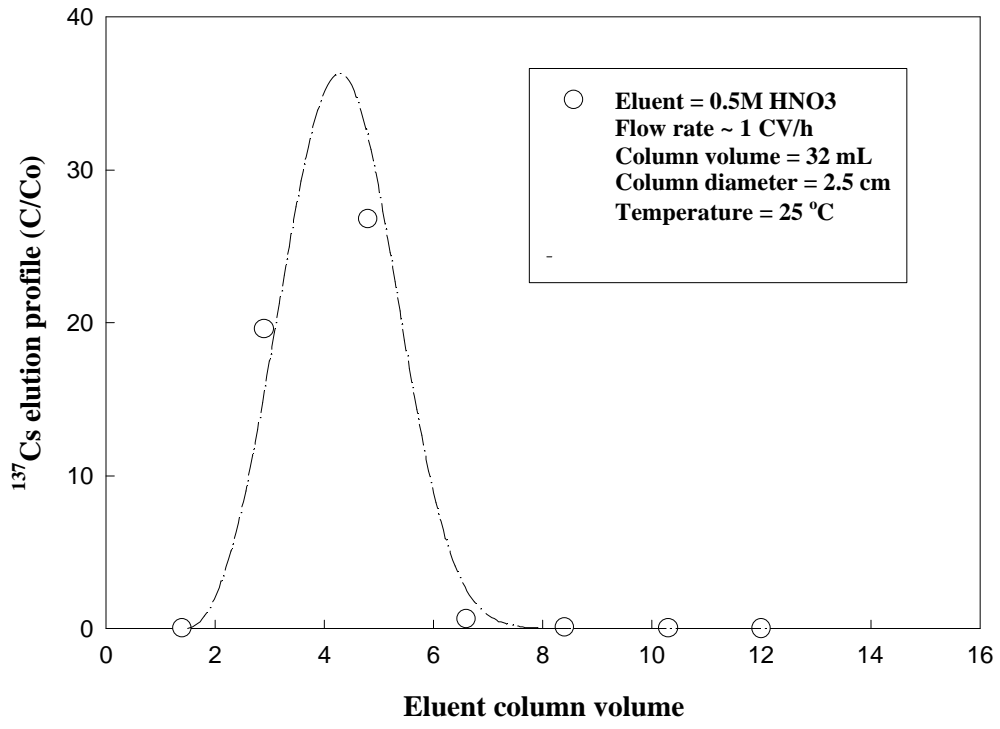

Figure 4. Cesium Elution profile for SuperLig 644 resin 


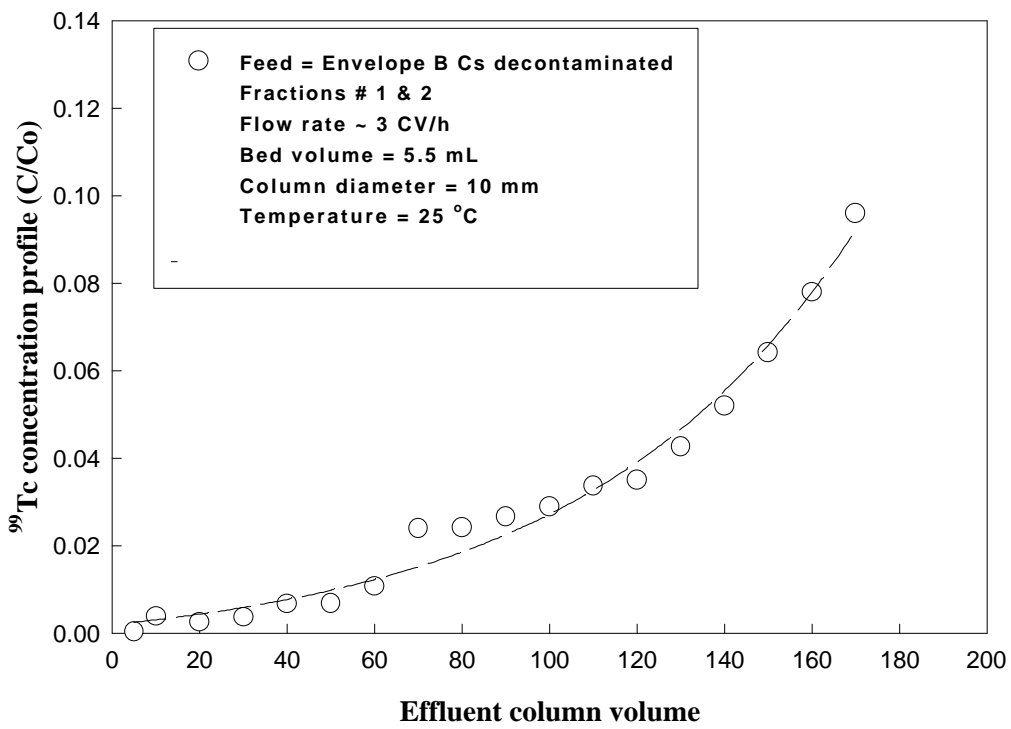

Figure 5. Technetium breakthrough curve for SuperLig 639 resin

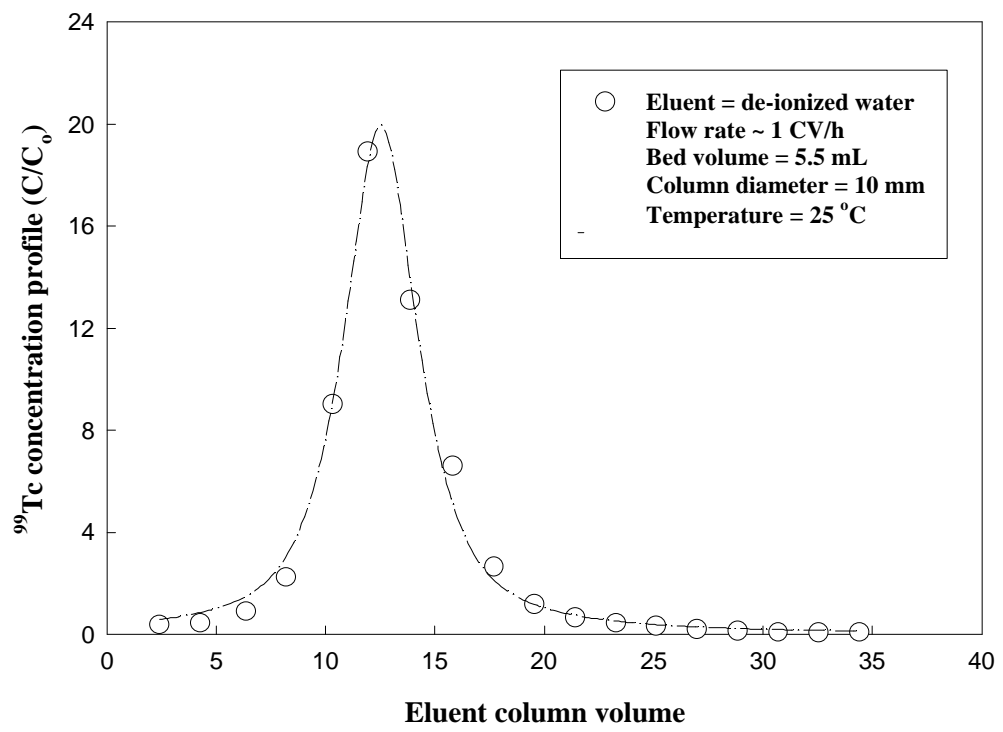

Figure 6. Technetium elution profile for SuperLig 639 resin 


\subsection{APPENDIX}

7.1 Attachment 1. As-prepared Tank 241-AZ-101 Simulant Composition

\begin{tabular}{|c|c|}
\multicolumn{1}{c}{ Chemical } & \multicolumn{1}{c}{ Molarity } \\
\hline $\mathrm{NH}_{4} \mathrm{NO}_{3}$ & $1.08 \mathrm{E}-02$ \\
\hline $\mathrm{CsNO}_{3}$ & $1.70 \mathrm{E}-04$ \\
\hline $\mathrm{KNO}_{3}$ & $6.98 \mathrm{E}-02$ \\
\hline $\mathrm{ZrO}\left(\mathrm{NO}_{3}\right)_{2}$ & $2.13 \mathrm{E}-05$ \\
\hline $\mathrm{NaCl}$ & $3.32 \mathrm{E}-03$ \\
\hline $\mathrm{NaF}$ & $5.63 \mathrm{E}-02$ \\
\hline $\mathrm{Na}_{2} \mathrm{SO}_{4}$ & $1.09 \mathrm{E}-01$ \\
\hline $\mathrm{Al}(\mathrm{OH})_{3}$ & $2.33 \mathrm{E}-01$ \\
\hline $\mathrm{NaOH}$ & $5.50 \mathrm{E}-01$ \\
\hline $\mathrm{Na}_{3} \mathrm{PO}_{4}$ & $9.33 \mathrm{E}-03$ \\
\hline $\mathrm{Na}_{2} \mathrm{CO}_{3}$ & $2.27 \mathrm{E}-01$ \\
\hline $\mathrm{NaNO}_{3}$ & $6.39 \mathrm{E}-01$ \\
\hline $\mathrm{NaNO}_{2}$ & $8.34 \mathrm{E}-01$ \\
\hline $\mathrm{NaCrO}_{4}$ & $8.52 \mathrm{E}-03$ \\
\hline & \\
\hline $\mathrm{Total} \mathrm{Na}^{+}$ & 2.8 \\
\hline Free $\mathrm{OH}^{-}$ & $3.17 \mathrm{E}-01$ \\
\hline Total NO & \\
\hline
\end{tabular}


7.2 Attachment 2. Initial Analysis of SuperLig ${ }^{\circledR} 644$ Guard Column Grab Samples

\begin{tabular}{|l|c|c|c|}
\hline Guard column sample ID & \# CV processed & Cs-137 $(\boldsymbol{\mu C i} / \mathbf{m L})$ & Concentration profile (C/Co) \\
\hline BNF-3-B315-NB99-23-GC-FS-6 & 48.3 & $1.67 \mathrm{E}+01$ & 0.016 \\
\hline BNF-3-B315-NB99-23-GC-FS-7* & 56.4 & $1.76 \mathrm{E}-02$ & $1.65 \mathrm{E}-05$ \\
\hline BNF-3-B315-NB99-23-GC-FS-8* & 64.8 & $4.94 \mathrm{E}-02$ & $4.63 \mathrm{E}-05$ \\
\hline BNF-3-B315-NB99-23-GC-FS-9 & 86.5 & $7.83 \mathrm{E}+01$ & 0.073 \\
\hline BNF-3-B315-NB99-23-GC-FS-10 & 88.9 & $1.12 \mathrm{E}+02$ & 0.105 \\
\hline
\end{tabular}

*Analysis results for these samples were inconsistent with analysis of the guard column effluent composite bottles and (Attachment 7.4). A second set of samples was submitted for analysis, which gave the expected results. This data from the second set of analyses is provided in Table 7 and plotted in Figure 3 .

\subsection{Attachment 3. SuperLig ${ }^{\circledR} 644$ Guard Column Effluent Composite Bottle Analysis}

\begin{tabular}{|l|c|c|c|}
\hline Guard column sample ID & \# CV processed & Cs-137 $(\boldsymbol{\mu C i} / \mathbf{m L})$ & Concentration profile (C/Co) \\
\hline BNF-3-B315-NB99-23-GC-FC-1 & 17.6 & $8.70 \mathrm{E}-02$ & $8.16 \mathrm{E}-05$ \\
\hline BNF-3-B315-NB99-23-GC-FC-1-D & 17.6 & $8.70 \mathrm{E}-02$ & $8.16 \mathrm{E}-05$ \\
\hline BNF-3-B315-NB99-23-GC-FC-2 & 28.9 & $1.43 \mathrm{E}+00$ & $1.34 \mathrm{E}-03$ \\
\hline BNF-3-B315-NB99-23-GC-FC-2-D & 28.9 & $1.40 \mathrm{E}+00$ & $1.31 \mathrm{E}-03$ \\
\hline BNF-3-B315-NB99-23-GC-FC-3 & 44.1 & $8.54 \mathrm{E}+00$ & $8.01 \mathrm{E}-03$ \\
\hline BNF-3-B315-NB99-23-GC-FC-4 & 58.5 & $3.16 \mathrm{E}+01$ & 0.0297 \\
\hline BNF-3-B315-NB99-23-GC-FC-5 & 76.4 & $8.58 \mathrm{E}+01$ & 0.0805 \\
\hline BNF-3-B315-NB99-23-GC-FC-6 & 85.0 & $1.22 \mathrm{E}+02$ & 0.1149 \\
\hline
\end{tabular}

\subsection{Attachment 4. SuperLig ${ }^{\circledR} 644$ Guard Column Effluent Fractions Cs-137 Breakthrough Profile with the AZ-102 Sample}

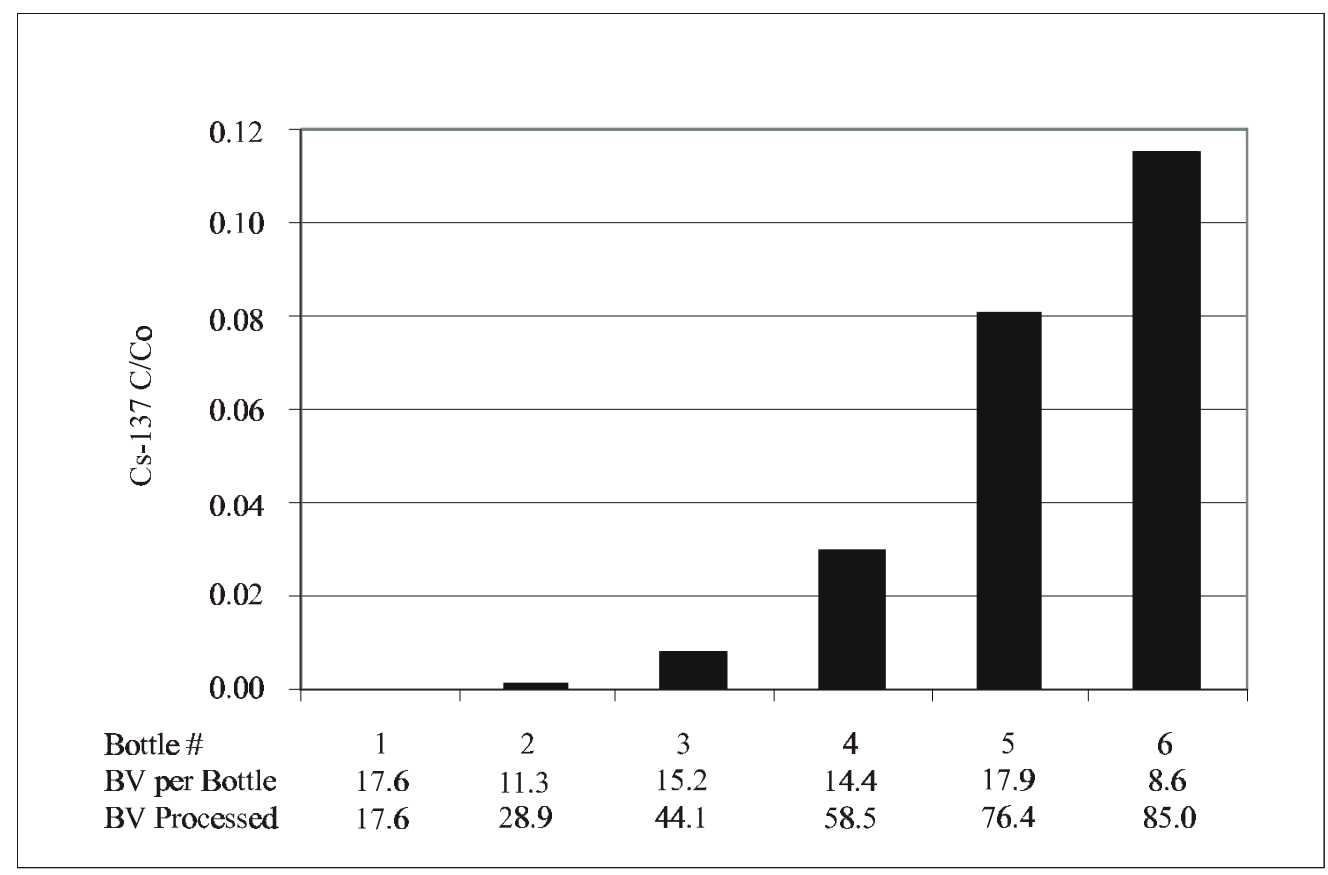




\subsection{Attachment 5. SuperLig ${ }^{\circledR} 644$ Batch Filtrate Solutions ICP-ES Analysis}

\begin{tabular}{|c|c|c|c|c|c|c|c|c|c|c|c|c|}
\hline analyte & & $\begin{array}{c}\text { AZ-102- } \\
\text { feed }\end{array}$ & & $\begin{array}{c}\text { Hay } \\
\text { AZ-102 } \\
\text { Filtrate } \\
\text { (ref. 10) }\end{array}$ & & $\begin{array}{l}\text { AZ-102 } \\
\text { control }\end{array}$ & & $\begin{array}{c}\text { Standard } \\
\text { batch }\end{array}$ & & $1^{\text {st }}$ recontact & & $\begin{array}{c}2^{\text {nd }} \\
\text { recontact }\end{array}$ \\
\hline $\mathrm{Al}(\mathrm{mg} / \mathrm{L})$ & & $6.26 \mathrm{E}+02$ & & $7.53 \mathrm{E}+02$ & & $7.25 \mathrm{E}+02$ & & $7.83 \mathrm{E}+02$ & & $2.38 \mathrm{E}+02$ & & $3.43 \mathrm{E}+01$ \\
\hline B & & $4.88 \mathrm{E}+00$ & & $4.71 \mathrm{E}+00$ & & $2.50 \mathrm{E}+01$ & & $4.62 \mathrm{E}+00$ & & $3.64 \mathrm{E}+00$ & & $3.10 \mathrm{E}+00$ \\
\hline $\mathrm{Ba}$ & $<$ & $2.28 \mathrm{E}-01$ & $<$ & 0.5000 & $<$ & $2.16 \mathrm{E}+00$ & $<$ & $2.12 \mathrm{E}+00$ & $<$ & $1.82 \mathrm{E}-01$ & $<$ & $1.82 \mathrm{E}-01$ \\
\hline $\mathrm{Ca}$ & & $3.03 \mathrm{E}+00$ & & $1.08 \mathrm{E}+02$ & & $9.00 \mathrm{E}+01$ & & $9.32 \mathrm{E}+01$ & & $2.22 \mathrm{E}+00$ & & $1.89 \mathrm{E}+00$ \\
\hline $\mathrm{Cd}$ & $<$ & $3.42 \mathrm{E}-01$ & $<$ & 0.7500 & $<$ & $3.24 \mathrm{E}+00$ & $<$ & $3.18 \mathrm{E}+00$ & $<$ & $2.73 \mathrm{E}-01$ & $<$ & $2.73 \mathrm{E}-01$ \\
\hline $\mathrm{Co}$ & $<$ & $5.70 \mathrm{E}-01$ & $<$ & 1.5000 & & $5.70 \mathrm{E}+00$ & & $6.22 \mathrm{E}+00$ & $<$ & $4.55 \mathrm{E}-01$ & $<$ & $4.55 \mathrm{E}-01$ \\
\hline $\mathrm{Cr}$ & & $7.68 \mathrm{E}+02$ & & $7.68 \mathrm{E}+02$ & & $8.49 \mathrm{E}+02$ & & $7.80 \mathrm{E}+02$ & & $6.73 \mathrm{E}+02$ & & $7.01 \mathrm{E}+02$ \\
\hline $\mathrm{Cu}$ & $<$ & $3.42 \mathrm{E}-01$ & $<$ & 1.250 & & $3.45 \mathrm{E}+00$ & & $3.32 \mathrm{E}+00$ & $<$ & $2.73 \mathrm{E}-01$ & $<$ & $2.73 \mathrm{E}-01$ \\
\hline $\mathrm{Fe}$ & $<$ & $3.42 \mathrm{E}-01$ & $<$ & 1.0000 & $<$ & $6.47 \mathrm{E}+00$ & $<$ & $6.36 \mathrm{E}+00$ & $<$ & $5.46 \mathrm{E}-01$ & $<$ & $5.46 \mathrm{E}-01$ \\
\hline $\mathrm{La}$ & $<$ & $1.25 \mathrm{E}+00$ & 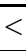 & 5.2500 & $<$ & $1.19 \mathrm{E}+01$ & $<$ & $1.17 \mathrm{E}+01$ & $<$ & $1.00 \mathrm{E}+00$ & $<$ & $1.00 \mathrm{E}+00$ \\
\hline $\mathrm{Li}$ & $<$ & $2.28 \mathrm{E}-01$ & $<$ & 1.0000 & $<$ & $2.16 \mathrm{E}+00$ & $<$ & $2.12 \mathrm{E}+00$ & $<$ & $1.82 \mathrm{E}-01$ & $<$ & $1.82 \mathrm{E}-01$ \\
\hline $\mathrm{Mg}$ & $<$ & $1.14 \mathrm{E}-01$ & $<$ & 0.5000 & & $2.24 \mathrm{E}+00$ & & $2.55 \mathrm{E}+00$ & $<$ & $9.10 \mathrm{E}-02$ & $<$ & $9.10 \mathrm{E}-02$ \\
\hline $\mathrm{Mn}$ & $<$ & $1.14 \mathrm{E}-01$ & $<$ & 0.7500 & $<$ & $1.08 \mathrm{E}+00$ & $<$ & $1.06 \mathrm{E}+00$ & $<$ & $9.10 \mathrm{E}-02$ & $<$ & $9.10 \mathrm{E}-02$ \\
\hline Mo & & $5.58 \mathrm{E}+01$ & & $5.86 \mathrm{E}+01$ & & $6.38 \mathrm{E}+01$ & & $5.83 \mathrm{E}+01$ & & $5.53 \mathrm{E}+01$ & & $5.86 \mathrm{E}+01$ \\
\hline $\mathrm{Na}$ & & $6.59 \mathrm{E}+04$ & & $6.37 \mathrm{E}+04$ & & $6.82 \mathrm{E}+04$ & & $6.49 \mathrm{E}+04$ & & $5.85 \mathrm{E}+04$ & & $6.14 \mathrm{E}+04$ \\
\hline $\mathrm{Ni}$ & $<$ & $7.98 \mathrm{E}-01$ & & 1.7500 & $<$ & $7.55 \mathrm{E}+00$ & $<$ & $7.42 \mathrm{E}+00$ & $<$ & $6.37 \mathrm{E}-01$ & $<$ & $6.37 \mathrm{E}-01$ \\
\hline $\mathrm{P}$ & & $1.73 \mathrm{E}+02$ & & $1.68 \mathrm{E}+02$ & & $2.12 \mathrm{E}+02$ & & $2.14 \mathrm{E}+02$ & & $1.56 \mathrm{E}+02$ & & $1.50 \mathrm{E}+02$ \\
\hline $\mathrm{Pb}$ & $<$ & $3.19 \mathrm{E}+00$ & 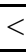 & 8.2500 & $<$ & $3.02 \mathrm{E}+01$ & $<$ & $2.97 \mathrm{E}+01$ & $<$ & $2.55 \mathrm{E}+00$ & $<$ & $2.55 \mathrm{E}+00$ \\
\hline $\mathrm{Si}$ & & $7.38 \mathrm{E}+01$ & $<$ & 6.9667 & & $8.88 \mathrm{E}+01$ & & $7.97 \mathrm{E}+01$ & & $1.07 \mathrm{E}+01$ & & $1.22 \mathrm{E}+01$ \\
\hline $\mathrm{Sn}$ & & $1.04 \mathrm{E}+01$ & $<$ & 4.5000 & & $2.66 \mathrm{E}+01$ & & $2.84 \mathrm{E}+01$ & & $9.82 \mathrm{E}+00$ & & $9.41 \mathrm{E}+00$ \\
\hline $\mathrm{Sr}$ & $<$ & $1.14 \mathrm{E}-01$ & $<$ & 0.2500 & $<$ & $1.08 \mathrm{E}+00$ & & $1.20 \mathrm{E}+00$ & $<$ & $9.10 \mathrm{E}-02$ & $<$ & $9.10 \mathrm{E}-02$ \\
\hline $\mathrm{Tc}$ & & $1.11 \mathrm{E}+01$ & & $1.07 \mathrm{E}+01$ & & $2.06 \mathrm{E}+01 *$ & & $1.85 \mathrm{E}+01 *$ & & $9.65 \mathrm{E}+00$ & & $9.00 \mathrm{E}+00$ \\
\hline $\mathrm{Ti}$ & $<$ & $2.28 \mathrm{E}-01$ & $<$ & 1.0000 & & $2.83 \mathrm{E}+00$ & & $2.62 \mathrm{E}+00$ & $<$ & $1.82 \mathrm{E}-01$ & $<$ & $1.82 \mathrm{E}-01$ \\
\hline $\mathrm{V}$ & $<$ & $3.42 \mathrm{E}-01$ & $<$ & 1.2500 & & $5.91 \mathrm{E}+00$ & & $5.87 \mathrm{E}+00$ & $<$ & $2.73 \mathrm{E}-01$ & $<$ & $2.73 \mathrm{E}-01$ \\
\hline $\mathrm{Zn}$ & $<$ & $3.42 \mathrm{E}-01$ & $<$ & 1.0000 & & $6.29 \mathrm{E}+00$ & & $5.78 \mathrm{E}+00$ & $\mid<$ & $2.73 \mathrm{E}-01$ & $<$ & $2.73 \mathrm{E}-01$ \\
\hline $\mathrm{Zr}$ & & $1.96 \mathrm{E}+00$ & 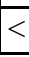 & 2.0000 & & $5.13 \mathrm{E}+00$ & & $6.27 \mathrm{E}+00$ & & $1.24 \mathrm{E}+00$ & & $2.45 \mathrm{E}+00$ \\
\hline
\end{tabular}

*The Tc analysis results for these samples was 2 times higher than was observed for the AZ-102 feed and filtrate samples and the recontact samples. Based on these observations, the Tc-99 results for these samples are considered to be incorrect. 


\subsection{Attachment 6. SuperLig ${ }^{\circledR} 644$ Column Swelling Data}

Lead Column

Guard Column

\begin{tabular}{|c|c|c|c|c|}
\hline & $\begin{array}{c}\text { Resin Ht. } \\
(\mathrm{cm})\end{array}$ & $\begin{array}{c}\text { Bed Volume } \\
(\mathrm{mL})\end{array}$ & $\begin{array}{c}\text { Resin Ht. } \\
(\mathrm{cm})\end{array}$ & $\begin{array}{c}\text { Bed Volume } \\
(\mathrm{mL})\end{array}$ \\
\hline $0.25 \mathrm{M} \mathrm{NaOH}$ & 5.70 & 32.4 & 5.50 & 31.2 \\
\hline Feed & 5.20 & 29.5 & 5.20 & 29.5 \\
\hline $0.1 \mathrm{M} \mathrm{NaOH} \mathrm{Wash}$ & 5.75 & 32.7 & --- & --- \\
\hline $0.5 \mathrm{M} \mathrm{HNO}_{3}$ & 4.00 & 22.7 & 4.00 & 22.7 \\
\hline
\end{tabular}

7.7 Attachment 7. SuperLig ${ }^{\circledR}$ 644 Lead Column Cs Eluate ICP-ES Analysis (1:50 and 1:20 Water Dilutions) Values shown are dilution-corrected

\begin{tabular}{|c|c|c|c|c|c|c|c|c|}
\hline ICP-ES & & $\begin{array}{l}1: 50 \\
\text { Water } \\
\text { Dilution }\end{array}$ & $\begin{array}{l}1: 50 \text { Water } \\
\text { Dilution - } \\
\text { Duplicate }\end{array}$ & $\begin{array}{l}1: 20 \text { Water } \\
\text { Dilution }\end{array}$ & $\begin{array}{l}1: 20 \text { Water } \\
\text { Dilution - } \\
\text { Duplicate }\end{array}$ \\
\hline $\mathrm{Al} \mathrm{(mg/L)}$ & & 790.50 & $<$ & 12.00 & & 149.90 & & 4.94 \\
\hline $\mathrm{B}$ & $<$ & 2.50 & $<$ & 2.50 & $<$ & 0.20 & $<$ & 0.2 \\
\hline $\mathrm{Ba}$ & $<$ & 1.00 & & 3.30 & & 1.08 & & 0.86 \\
\hline $\mathrm{Ca}$ & & 18.60 & & 2.30 & & 6.98 & & 2.14 \\
\hline $\mathrm{Cd}$ & $<$ & 1.50 & $<$ & 1.50 & & 1.92 & & 0.82 \\
\hline $\mathrm{Co}$ & $<$ & 157.50 & $<$ & 2.50 & $<$ & 0.20 & $<$ & 0.2 \\
\hline $\mathrm{Cr}$ & & 2.50 & & 20.25 & & 29.64 & & 27.24 \\
\hline $\mathrm{Cu}$ & $<$ & 25.55 & $<$ & 1.50 & & 0.30 & $<$ & 0.12 \\
\hline $\mathrm{Fe}$ & & 2.05 & & 1.85 & & 1.64 & & 0.82 \\
\hline $\mathrm{La}$ & $<$ & 5.50 & $<$ & 5.50 & $<$ & 0.44 & $<$ & 0.44 \\
\hline $\mathrm{Li}$ & $<$ & 1.00 & $<$ & 1.00 & $<$ & 0.08 & $<$ & 0.08 \\
\hline $\mathrm{Mg}$ & $<$ & 0.50 & $<$ & 0.50 & & 0.12 & $<$ & 0.04 \\
\hline $\mathrm{Mn}$ & $<$ & 0.50 & $<$ & 0.50 & & 0.32 & & 0.06 \\
\hline $\mathrm{Mo}$ & $<$ & 3.00 & $<$ & 3.00 & & 0.64 & $<$ & 0.24 \\
\hline $\mathrm{Na}$ & & $\mathrm{NM}$ & & 819.05 & & 3228.54 & & 1064.98 \\
\hline $\mathrm{Ni}$ & $<$ & 3.50 & $<$ & 3.50 & & 4.24 & $<$ & 0.28 \\
\hline $\mathrm{P}$ & & 19.20 & $<$ & 13.00 & & 26.80 & & 2.66 \\
\hline $\mathrm{Pb}$ & $<$ & 14.00 & $<$ & 14.00 & & 1.98 & $<$ & 1.12 \\
\hline $\mathrm{Si}$ & & 295.95 & & 169.60 & $<$ & 0.64 & $<$ & 0.64 \\
\hline $\mathrm{Sn}$ & $<$ & 7.50 & $<$ & 7.50 & $<$ & 0.60 & $<$ & 0.6 \\
\hline $\mathrm{Sr}$ & $<$ & 0.50 & $<$ & 0.50 & & 0.100 & $<$ & 0.04 \\
\hline $\mathrm{Ti}$ & $<$ & 1.00 & $<$ & 1.00 & $<$ & 0.08 & $<$ & 0.08 \\
\hline $\mathrm{V}$ & $<$ & 1.50 & $<$ & 1.50 & $<$ & 0.12 & $<$ & 0.12 \\
\hline $\mathrm{Zn}$ & & 1.65 & & 2.30 & & 1.04 & & 0.22 \\
\hline $\mathrm{Zr}$ & $<$ & 2.00 & $<$ & 2.00 & $<$ & 0.16 & $<$ & 0.16 \\
\hline $\mathrm{Sc}$ & & $\mathrm{NM}$ & $<$ & 8.50 & & $\mathrm{NM}$ & & $\mathrm{NM}$ \\
\hline $\mathrm{Tc}$ & & $\mathrm{NM}$ & & 2.75 & & $\mathrm{NM}$ & & $\mathrm{NM}$ \\
\hline & & & & & & & \\
\hline
\end{tabular}


7.8 Attachment 8. SuperLig ${ }^{\circledR} 644$ Guard Column Cs Eluate ICP-ES Analysis (1:30 $\mathrm{HNO}_{3}$ Dilution)

ICP-ES (mg/L)

\begin{tabular}{|c|c|c|c|c|c|c|}
\hline Sample ID & & $\begin{array}{c}\text { Cs-eluate- } \\
\text { product-1-1 }\end{array}$ & & $\begin{array}{c}\text { Cs-eluate- } \\
\text { product-1-2 }\end{array}$ & & $\begin{array}{l}\text { Avg. duplicate } \\
\text { samples }\end{array}$ \\
\hline $\mathrm{Al}$ & & $1.89 \mathrm{E}+00$ & & $1.89 \mathrm{E}+00$ & & $1.89 \mathrm{E}+00$ \\
\hline $\mathrm{B}$ & & $8.40 \mathrm{E}-01$ & & $8.40 \mathrm{E}-01$ & & $8.40 \mathrm{E}-01$ \\
\hline $\mathrm{Ba}$ & & $3.30 \mathrm{E}-01$ & & $4.50 \mathrm{E}-01$ & & $3.90 \mathrm{E}-01$ \\
\hline $\mathrm{Ca}$ & & $1.23 \mathrm{E}+01$ & & $1.26 \mathrm{E}+00$ & & $6.77 \mathrm{E}+00$ \\
\hline $\mathrm{Cd}$ & $<$ & $1.80 \mathrm{E}-01$ & $<$ & $1.80 \mathrm{E}-01$ & $<$ & $1.80 \mathrm{E}-01$ \\
\hline $\mathrm{Co}$ & $<$ & $3.00 \mathrm{E}-01$ & $<$ & $3.00 \mathrm{E}-01$ & $<$ & $3.00 \mathrm{E}-01$ \\
\hline $\mathrm{Cr}$ & & $2.21 \mathrm{E}+01$ & & $2.21 \mathrm{E}+01$ & & $2.21 \mathrm{E}+01$ \\
\hline $\mathrm{Cu}$ & $<$ & $1.80 \mathrm{E}-01$ & $<$ & $1.80 \mathrm{E}-01$ & $<$ & $1.80 \mathrm{E}-01$ \\
\hline $\mathrm{Fe}$ & & $2.28 \mathrm{E}+00$ & & $2.52 \mathrm{E}+00$ & & $2.40 \mathrm{E}+00$ \\
\hline $\mathrm{La}$ & $<$ & $6.60 \mathrm{E}-01$ & $<$ & $6.60 \mathrm{E}-01$ & $<$ & $6.60 \mathrm{E}-01$ \\
\hline $\mathrm{Li}$ & $<$ & $1.20 \mathrm{E}-01$ & $<$ & $1.20 \mathrm{E}-01$ & $<$ & $1.20 \mathrm{E}-01$ \\
\hline $\mathrm{Mg}$ & & $2.40 \mathrm{E}-01$ & & $1.50 \mathrm{E}-01$ & & $1.95 \mathrm{E}-01$ \\
\hline $\mathrm{Mn}$ & & $9.00 \mathrm{E}-02$ & & $9.00 \mathrm{E}-02$ & $<$ & $9.00 \mathrm{E}-02$ \\
\hline Mo & $<$ & $3.60 \mathrm{E}-01$ & $<$ & $3.60 \mathrm{E}-01$ & $<$ & $3.60 \mathrm{E}-01$ \\
\hline $\mathrm{Na}$ & & $8.68 \mathrm{E}+02$ & & $8.74 \mathrm{E}+02$ & & $8.71 \mathrm{E}+02$ \\
\hline $\mathrm{Ni}$ & $<$ & $4.20 \mathrm{E}-01$ & $<$ & $4.20 \mathrm{E}-01$ & $<$ & $4.20 \mathrm{E}-01$ \\
\hline $\mathrm{P}$ & $<$ & $1.92 \mathrm{E}+00$ & & $6.87 \mathrm{E}+00$ & & $4.40 \mathrm{E}+00$ \\
\hline $\mathrm{Pb}$ & $<$ & $1.68 \mathrm{E}+00$ & $<$ & $1.68 \mathrm{E}+00$ & $<$ & $1.68 \mathrm{E}+00$ \\
\hline $\mathrm{Si}$ & $<$ & $9.60 \mathrm{E}-01$ & $<$ & $9.60 \mathrm{E}-01$ & $<$ & $9.60 \mathrm{E}-01$ \\
\hline $\mathrm{Sn}$ & $<$ & $9.00 \mathrm{E}-01$ & $<$ & $9.00 \mathrm{E}-01$ & $<$ & $9.00 \mathrm{E}-01$ \\
\hline $\mathrm{Sr}$ & & $9.00 \mathrm{E}-02$ & $<$ & $6.00 \mathrm{E}-2$ & $<$ & $7.50 \mathrm{E}-2$ \\
\hline $\mathrm{Ti}$ & $<$ & $1.20 \mathrm{E}-01$ & $<$ & $1.20 \mathrm{E}-01$ & $<$ & $1.20 \mathrm{E}-01$ \\
\hline $\mathrm{V}$ & $<$ & $1.80 \mathrm{E}-01$ & $<$ & $1.80 \mathrm{E}-01$ & $<$ & $1.80 \mathrm{E}-01$ \\
\hline $\mathrm{Zn}$ & & $2.10 \mathrm{E}-01$ & $<$ & $1.80 \mathrm{E}-01$ & $<$ & $1.95 \mathrm{E}-01$ \\
\hline $\mathrm{Zr}$ & $<$ & $2.40 \mathrm{E}-01$ & $<$ & $2.40 \mathrm{E}-01$ & $<$ & $2.40 \mathrm{E}-01$ \\
\hline
\end{tabular}

